\title{
Novel indolylarylsulfone derivatives as covalent HIV-1 reverse transcriptase inhibitors specifically targeting the drug-resistant mutant Y181C
}

Ping Gao ${ }^{\mathrm{a}, \#}$, Shu Song ${ }^{\mathrm{a}, \#}$, Estrella Frutos-Beltrán ${ }^{\mathrm{b}, \#}$, Wenxin $\mathrm{Li}^{\mathrm{a}}$, Bin Sun ${ }^{\mathrm{c}}$, Dongwei Kang ${ }^{\mathrm{a}}$, Jinmi Zou ${ }^{\mathrm{a}}$, Jian Zhang ${ }^{\mathrm{a}}$, Christophe Pannecouque ${ }^{\mathrm{d}}$, Erik De Clercq ${ }^{\mathrm{d}}$, Luis Menéndez-Arias ${ }^{\mathrm{b}, *}$, Peng Zhan $^{\mathrm{a},}$, Xinyong Liua, ${ }^{\mathrm{a}, *}$

${ }^{a}$ Department of Medicinal Chemistry, Key Laboratory of Chemical Biology, Ministry of Education, School of Pharmaceutical Sciences, Shandong University, Ji'nan, 250012

${ }^{b}$ Centro de Biología Molecular "Severo Ochoa" (Consejo Superior de Investigaciones Científicas \& Universidad Autónoma de Madrid), Madrid, Spain

${ }^{c}$ Institute of BioPharmaceutical Research, Liaocheng University, 1 Hunan Road, Liaocheng 252000, PR China

${ }^{d}$ Rega Institute for Medical Research, K. U. Leuven, Minderbroedersstraat 10, B-3000 Leuven, Belgium

"E-mail: Imenendez@cbm.csic.es (Menéndez-Arias L.); xinyongl@sdu.edu.cn (Liu X.Y.); zhanpeng1982@sdu.edu.cn (Zhan P.).

${ }^{\#}$ These authors contributed equally to this work. 


\begin{abstract}
Non-nucleoside reverse transcriptase inhibitors (NNRTIs) are widely used in combination therapies against HIV-1. However, emergent and transmitted drug resistance compromise their efficacy in the clinical setting. Y181C is selected in patients receiving nevirapine, etravirine and rilpivirine, and together with $\mathrm{K} 103 \mathrm{~N}$ is the most prevalent NNRTI-associated mutation in HIVinfected patients. Herein, we report on the design, synthesis and biological evaluation of a novel series of indolylarylsulfones bearing acrylamide or ethylene sulfonamide reactive groups as warheads to inactivate Cys181-containing HIV-1 RT via a Michael addition reaction. Compounds I-7 and I-9 demonstrated higher selectivity towards the Y181C mutant than against the wild-type RT, in nucleotide incorporation inhibition assays. The larger size of the NNRTI binding pocket in the mutant enzyme facilitates a better fit for the active compounds, while stacking interactions with Phe227 and Pro236 contribute to inhibitor binding. Mass spectrometry data were consistent with the covalent modification of the RT, although off-target reactivity constitutes a major limitation for further development of the described inhibitors.
\end{abstract}

\title{
1. Introduction
}

The global pandemic of human immunodeficiency virus type 1 (HIV-1) remains as a major threat to human health worldwide [1]. Standard treatments against HIV-1 infection, including highly active antiretroviral therapies (HAART), often combine drugs targeting the three viral enzymes: protease, reverse transcriptase (RT) and integrase, among which RT has become the primary target for anti-HIV chemotherapy [2]. However, emergent and transmitted drug resistance hamper the effectiveness of antiretroviral therapies [3].

$\mathrm{K} 103 \mathrm{~N}$ and $\mathrm{Y} 181 \mathrm{C}$ are the most common mutations associated with resistance to nonnucleoside RT inhibitors (NNRTIs) and several studies have shown that their prevalence in NNRTIresistant viruses can be as high as 40-60\% for K103N, and 15-25\% for Y181C [4, 5]. Recent studies have also shown an increased prevalence of those mutations among transmitted drug-resistant viruses in different regions of the world, most notably Sub-Saharan Africa and Latin America [6, 7].

Although Y181C has been usually associated with high-level resistance to nevirapine (a first generation NNRTI), this amino acid substitution can be selected in vivo after exposure to etravirine or rilpivirine, while conferring 3- to 5-fold reduced susceptibility to those drugs in phenotypic assays 
(reviewed in refs. [3, 5]). Many efforts in antiretroviral therapy have been focused on the possibility of blocking replication of HIV strains carrying the Y181C substitution in their RT. An attractive approach involves the covalent modification of the enzyme through targeting Cys181. Recently, Chan et al. [8] described 2-naphthyl phenyl ether derivatives containing $\alpha$-halo amide and acrylamide warheads that eliminated the activity of Cys181-containing HIV-1 RT. These compounds showed similar efficacy against the wild-type (WT) RT in in vitro assays, with $\mathrm{IC}_{50}$ in the low micromolar range.

In this report, we have used indolylarylsulfones to develop new covalent inhibitors targeting Cys181 in HIV-1 RT. Indolylarylsulfone derivatives constitute a potent class of NNRTIs developed from the Merck prototype compound L-737,126 [9] (Fig. 1). Derivatives of this molecule have shown inhibitory activities against the WT virus in the nanomolar range [10] (reviewed in [11]). Crystallography and molecular studies based on the complex of HIV-1 RT and the indolylarylsulfone derivative 7e (Figure 1) showed that the saturated pyrrole ring locates at the hydrophobic pocket lined by residues Tyr181, Tyr188, Phe227 and Tyr318 [12]. The antiviral activity of sulfonamide $\mathbf{7 e}$ was similar to that previously reported for L-737,126 [9, 12]. Assuming the location of the saturated pyrrol ring close to position 181, we predicted that the introduction of a reactive group through a Michael reaction would facilitate the formation of a covalent bond with the mutated cysteine thereby blocking the activity of the Y181C mutant RT.

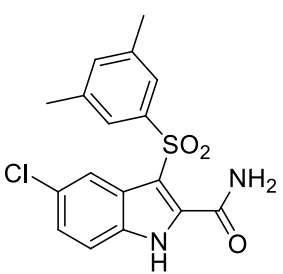

L-737,126<smiles>NC(=O)c1[nH]c2ccc(Br)cc2c1S(=O)(=O)N1CCCC1</smiles>

$7 e$

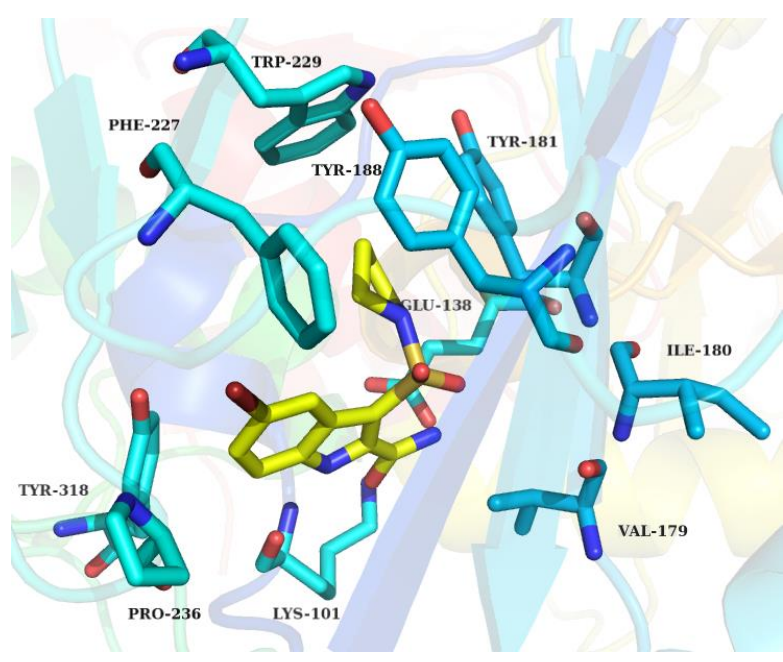

Fig. 1. Indolylarylsulfone derivatives and schematic diagram showing the location of compound 7e within the NNRTI binding pocket of HIV-1 RT. Compound 7e (yellow) and amino acid side chains in the binding pocket (blue) are shown using a stick representation. The figure was generated with 
the PyMol software (www.pymol.org). Coordinates were taken from the Protein Data Bank (file 2RF2) [12].

Acrylamide and ethylene sulfonamide "warheads" were introduced to explore the possibility of obtaining covalently modified Y181C RTs. Indolylarylsulfone derivatives containing rings of different sizes (five- and six-membered) were synthesized and tested in enzymatic and cell-based assays to explore structure diversity and potential improvements in their inhibition capacity. Our results show the specific inhibition of the HIV-1 RT mutant Y181C through covalent modification of the enzyme using indolylarylsulfone derivatives, but underline limitations caused by off-target covalent binding that may result in relatively high cytotoxicity.

\section{Results and Discussion}

\subsection{Chemistry}

The synthetic routes of novel indolylarylsulfone derivatives are outlined in Scheme 1. Target compounds were synthesized from the commercially available starting material ethyl 5bromoindole-2-carboxylate (1). First, compound $\mathbf{1}$ was reacted with concentrated sulfuric acid in acetic anhydride solution to obtain intermediate 5-bromo-2-ethyl ester-1H-indole-3-sulfonic acid (2). Then, further reaction with oxalyl chloride in dichloromethane and a catalytic amount of dimethylformamide led to the synthesis of ethyl 5-bromo-3-(chlorosulfonyl)-1H-indole-2carboxylate (3). Compound $\mathbf{3}$ reacted with different amino substituents to generate the compounds of series $\mathbf{4}$. Then, these molecules were esterified into amides (under ammonia gas) to form the $\mathbf{5}$ series of intermediates. Finally, the $t$-butyloxycarboryl group was removed under trifluoroacetic acid, and the exposed amino groups were acylated with acryloyl chloride or ethylenesulfonyl chloride to obtain the target compounds. 


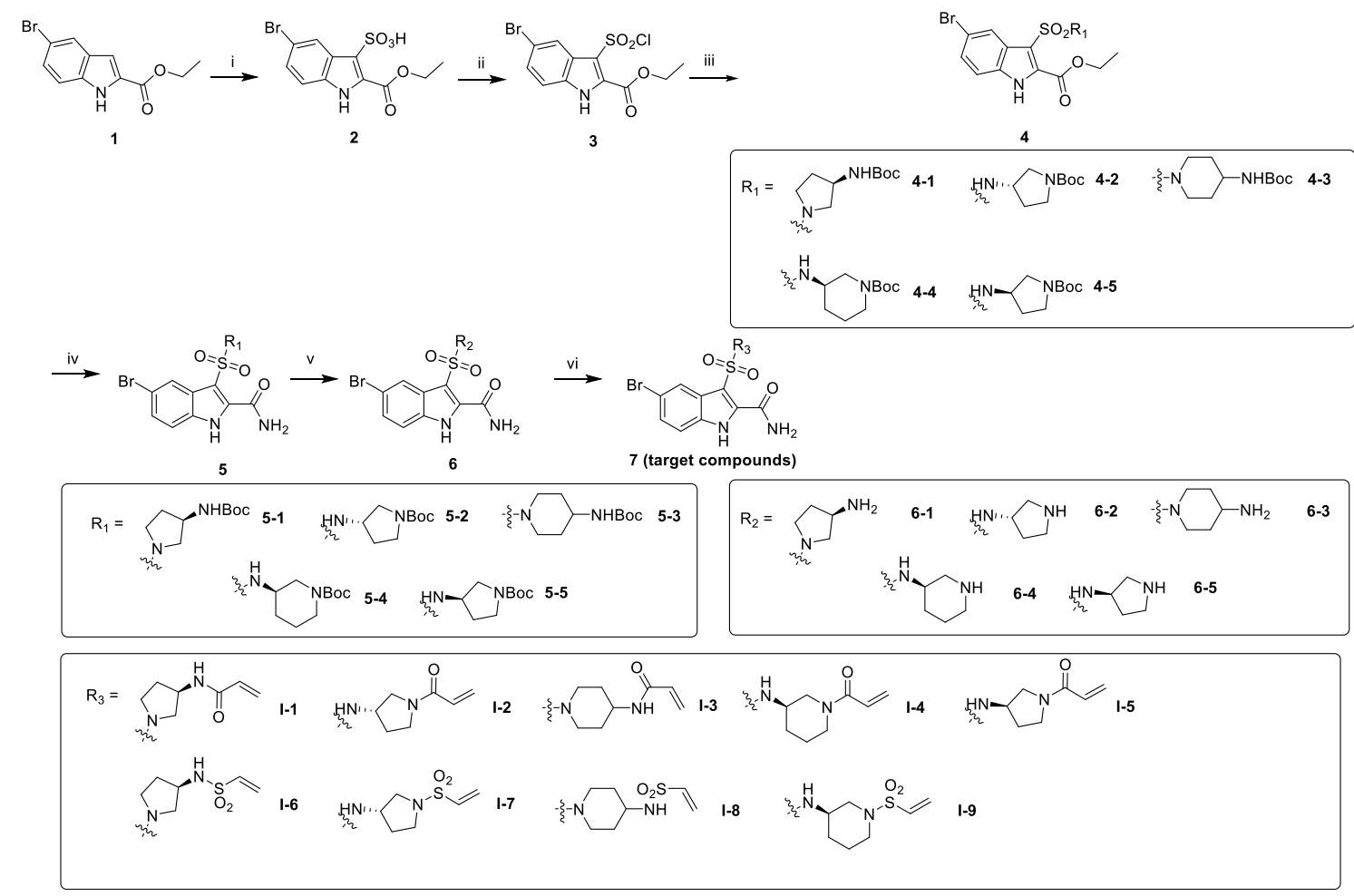

Scheme 1. Reagents and conditions: (i) $\mathrm{H}_{2} \mathrm{SO}_{4}$, acetic anhydride, r.t., 15 h. (ii) oxalyl chloride, DMF, DCM, reflux, 3 h. (iii) substituted alkylamine, DCM, $\mathrm{Et}_{3} \mathrm{~N}$, r.t., overnight. (iv) $\mathrm{NH}_{3}, \mathrm{CH}_{3} \mathrm{OH}, 70^{\circ} \mathrm{C}$, overnight. (v) TFA, DCM, r.t., overnight. (vi) acryloyl chloride or 2-chloroethanesulfonyl chloride, THF, Et ${ }_{3} \mathrm{~N}, 12 \mathrm{~h}$.

\subsection{Biological activity}

\subsubsection{Antiviral activity in cell culture and HIV-1 RT inhibition assays}

The synthesized indolylarylsulfones were first evaluated in cell culture assays for their antiHIV activity against WT HIV-1 and HIV-2 strains (IIIB and ROD, respectively). Efavirenz and compound 7e were used as positive controls. As shown in Fig. 2, most of the compounds were inactive and showed relatively high cytotoxicity, although some inhibition was observed with compounds I-3 and I-7. The most potent derivative was I-7 and showed an $\mathrm{IC}_{50}$ of $9.74 \pm 0.34 \mu \mathrm{M}$ against WT HIV-1. No inhibition was observed with any of the tested compounds when tested against WT HIV-2 ROD (data not shown). 


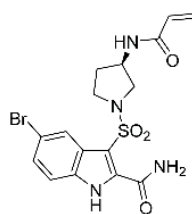

I-1

$\mathrm{EC}_{50}>178 \mu \mathrm{M}$

$\mathrm{CC}_{50}=178 \mu \mathrm{M}$

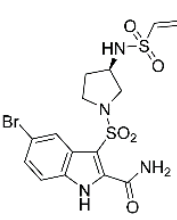

I-6

$\mathrm{EC}_{50}>2.1 \mu \mathrm{M}$

$\mathrm{CC}_{50}=2.1 \pm 0.5 \mu \mathrm{M}$

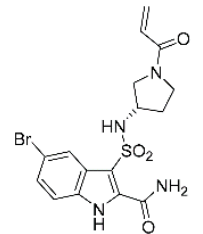

I-2

$\mathrm{EC}_{50}>155.2 \mu \mathrm{M}$

$\mathrm{CC}_{50}=155.2 \mu \mathrm{M}$

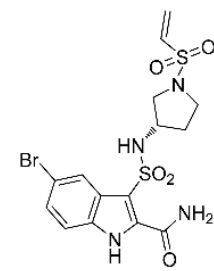

I-7

$\mathrm{EC}_{50}=9.74 \pm 0.34 \mu \mathrm{M}$

$\mathrm{CC}_{50}=16.0 \pm 3.6 \mu \mathrm{M}$

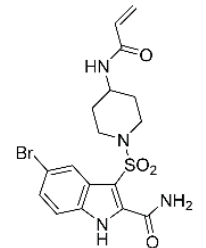

I-3

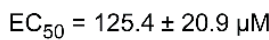

$\mathrm{CC}_{50}>274.5 \mu \mathrm{M}$

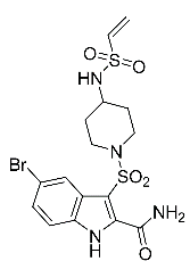

I-8

$\mathrm{EC}_{50}>6.5 \mu \mathrm{M}$

$\mathrm{CC}_{50}=6.5 \pm 0.7 \mu \mathrm{M}$

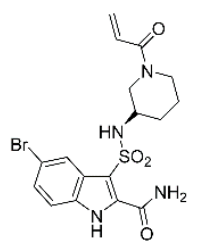

I-4

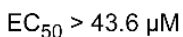

$\mathrm{CC}_{50}=43.6 \mu \mathrm{M}$

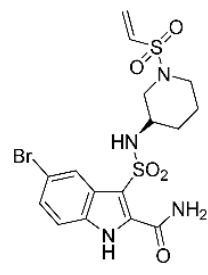

I-9

$\mathrm{EC}_{50}>29.0 \mu \mathrm{M}$

$\mathrm{CC}_{50}=29.0 \pm 2.9 \mu \mathrm{M}$

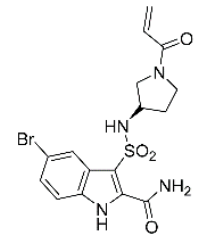

I-5

$\mathrm{EC}_{50}>51.8 \mu \mathrm{M}$

$\mathrm{CC}_{50}=51.8 \pm 3.3 \mu \mathrm{M}$

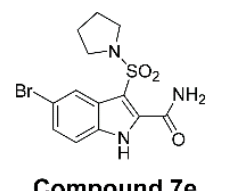

$\mathrm{EC}_{50}=3.6 \pm 0.1 \mathrm{nM}$

$\mathrm{CC}_{50}=35.3 \pm 5.3 \mu \mathrm{M}$

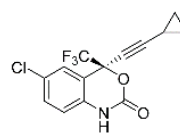

Efavirenz

$\mathrm{EC}_{50}=8.5 \pm 0.1 \mathrm{nM}$

$\mathrm{CC}_{50}>6.3 \mu \mathrm{M}$

Fig. 2. Antiviral activity against the WT HIV-1 IIIB strain of indolylarylsulfone derivatives in MT4 cell culture assays. $\mathrm{EC}_{50}$ indicates the concentration of compound required to achieve 50\% protection against HIV-1-induced cytotoxicity, as determined by the MTT method. $\mathrm{CC}_{50}$ is the concentration required to reduce the viability of mock-infected cell cultures by $50 \%$, as determined by the MTT method.

The structure-activity relationship (SAR) analysis based on the results of the antiviral assays showed that the compounds with the ethylene sulfonamide substitution all exhibited higher cytotoxicity than those with acrylamide warheads, indicating that ethylene sulfonamide is potentially more toxic. As to the acrylamide substitution series (compounds I-1 to I-5), SAR analysis reveals that: (i) the lowest toxicitity (highest $\mathrm{CC}_{50}$ ) is shown by the six-membered ringsubstituted compound I-3 that lacks a chiral center; (ii) if the acrylamide reactive group is attached to a chiral carbon atom, the compound is more toxic when the $\mathrm{C}$ atom is in the $S$ configuration $\left(\mathrm{CC}_{50}\right.$ : I-2 > I-4, I-5); and (iii) for compounds without the ethylene sulfonamide warhead (I-1 to I-5), higher toxicities were shown by molecules containing an extended sulfonamide linker between the two rings $\left(\mathrm{CC}_{50}\right.$ : I-1, I-3 > I-2, I-4, I-5).

In contrast, in the series containing the ethylene sulfonamide warhead (compounds I-6 to I-9), longer linkers due to the presence of an amide between the sulfonyl group and the piperidine and pyrrolidine rings, as in compounds I-7 and I-9, reduced their toxicity in comparison to I-6 and I-8. 
Despite their cytotoxicity and weak inhibitory activity of all tested compounds in cell culture assays, we also determined their inhibitory potential in nucleotide incorporation assays carried out with heteropolymeric template-primers. In agreement with the results of the cell culture experiments, none of the indolylarylsulfone derivatives showed significant activity against WT HIV-1 RT (BH10 RT) at $100 \mu \mathrm{M}$ (Fig. 3). However, I-7 showed potent inhibitory activity against mutant Y181C RT. Efavirenz, L-737,126 (5-bromo-3-(pyrrolidin-1-ylsulfonyl)-1H-indole-2-carboxamide; 2rf2) and compound $7 \mathrm{e}[9,12]$ used as controls, were effective inhibitors of both WT and Y181C RTs, although L-737,126 and 7e were less effective against Y181C (Fig. 3).

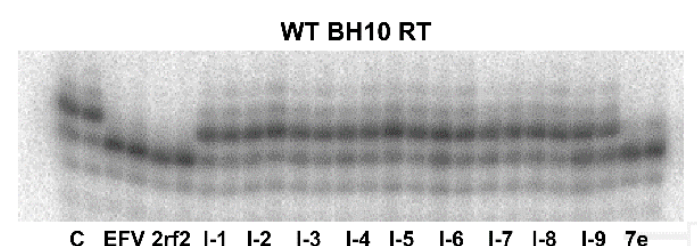

$\begin{array}{llllllllllll}C & \text { EFV } 2 r f 2 & \text { I-1 } & \text { I-2 } & \text { I-3 } & \text { I-4 } & \text { I-5 } & \text { I-6 } & \text { I-7 } & \text { I-8 } & \text { I-9 } & 7 e\end{array}$

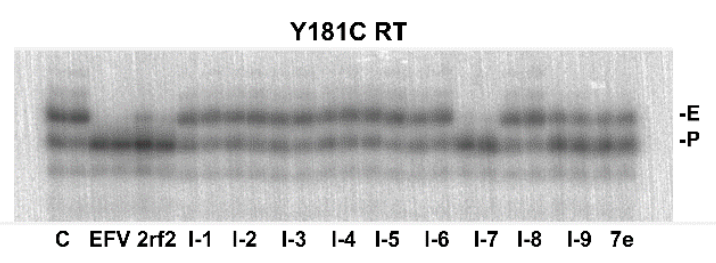

Y181C RT

Fig. 3. Nucleotide incorporation assays carried out with WT and mutant RTs. Assays were carried out with template-primer D38/[32P]25PGA. Enzyme and template-primer were supplied at 12 and $30 \mathrm{nM}$, respectively. The incorporation reaction was carried out at $37^{\circ} \mathrm{C}$ in the presence of inhibitor and dTTP at $100 \mu \mathrm{M}$ each. Aliquots were taken after 15 and $30 \mathrm{~s}$. C shows control experiments carried out in the absence of inhibitor. $\mathrm{P}$ and $\mathrm{E}$ indicate the position of the labeled primer (25PGA), and the extended product after the incorporation of dTTP, respectively. $2 \mathrm{rf} 2$ stands for compound L-737,126.

Compounds I-7 and I-9 showed the largest inhibitory effect against Y181C RT in single nucleotide incorporation assays (Fig. 3). Their 50\% inhibitory concentrations ( $\mathrm{IC}_{50} \mathrm{~s}$ ) against WT HIV- $1_{\mathrm{BH} 10} \mathrm{RT}$ and mutant $\mathrm{Y} 181 \mathrm{C}$ are shown in Table 1. In these experiments, efavirenz and compound $7 \mathrm{e}$ were used as controls and were found to be active against both enzymes, although the inhibitory capacity of compound $7 \mathrm{e}$ was reduced by $>100$-fold in the case of mutant $\mathrm{Y} 181 \mathrm{C}$, in agreement with previous reports showing its lower efficacy in antiviral assays against the mutant virus [12]. HPLC analysis showed that after a 24-hour incubation at $\mathrm{pH} 2.0$ and 7.4 (in phosphate buffer), I-7 remained stable, showing the same mobility than at time 0 , and retaining more than $95 \%$ peak intensity after reverse-phase chromatography.

I-7 and I-9 failed to inhibit the WT RT at concentrations as high as $100 \mu \mathrm{M}$. However, both 
compounds inhibited the mutant $\mathrm{Y} 181 \mathrm{C}$ RT with $\mathrm{IC}_{50}$ values of $18.2 \pm 4.1 \mu \mathrm{M}$ and $75.2 \pm 8.9 \mu \mathrm{M}$ for I-7 and I-9, respectively. Their inhibitory activity was not largely affected by dithiothreitol (DTT), although I-7 showed higher potency when DTT was excluded from the reaction mixture $\left(\mathrm{IC}_{50}=11.3 \pm 2.09 \mu \mathrm{M}\right)$. All the nucleotide incorporation reactions were carried out after preincubating the enzyme with the inhibitor for $5 \mathrm{~min}$ at $37^{\circ} \mathrm{C}$. However, in the absence of DTT, when the incubation time was extended to $60 \mathrm{~min}$, the $\mathrm{IC}_{50}$ value for $\mathbf{I}-7$ against $\mathrm{Y} 181 \mathrm{C}$ RT decreased to $2.26 \pm 0.68 \mu \mathrm{M}$.

Table 1. Inhibitory activity of selected compounds in nucleotide incorporation assays.

\begin{tabular}{|l|l|l|l|}
\hline \multirow{2}{*}{ Compounds } & \multicolumn{3}{|c|}{$\mathrm{IC}_{50}(\mu \mathrm{M})$} \\
\cline { 2 - 4 } & \multicolumn{1}{|c|}{ WT BH10 } & \multicolumn{2}{|c|}{ Y181C RT } \\
\cline { 2 - 4 } & Standard conditions & Standard conditions & Without DTT \\
\hline I-7 & $>100 *$ & $18.2 \pm 4.1$ & $11.3 \pm 2.1$ \\
\hline I-9 & $>100 *$ & $75.2 \pm 8.9$ & $79.9 \pm 15.0$ \\
\hline Compound 7e & $0.48 \pm 0.09$ & $59.0 \pm 8.1$ & ND \\
\hline Efavirenz & $0.18 \pm 0.01$ & $0.24 \pm 0.02$ & ND \\
\hline
\end{tabular}

* Less than $5 \%$ inhibition at $100 \mu \mathrm{M}$ concentration of the inhibitor. ND, not determined.

The antiviral activity of I-7 and I-9 was also tested in cell culture against WT and mutant HIV1 IIIB strains. As shown in Table 2, both compounds showed some activity against the mutant virus, although with relatively low selectivity indexes (9.3 and 7.7, for $\mathbf{I}-\mathbf{7}$ and $\mathbf{I - 9}$, respectively) due to the cytotoxicity of those compounds. Despite these limitations, I-7 shows measurable antiviral activity by targeting Cys181 in the HIV-1 NNRTI binding site.

Table 2. Activity against WT and mutant HIV-1 IIIB strains and cytotoxicity in MT-4 cells.

\begin{tabular}{|l|c|c|c|}
\hline \multirow{2}{*}{ Compounds } & \multicolumn{2}{|c|}{$\mathrm{EC}_{50}(\mu \mathrm{M})^{\mathrm{a}}$} & \multirow{2}{*}{$\mathrm{CC}_{50}(\mu \mathrm{M})^{\mathrm{b}}$} \\
\cline { 2 - 3 } & $\mathrm{WT}$ & $\mathrm{Y} 181 \mathrm{C}$ & \\
\hline I-7 & $9.74 \pm 0.34$ & $2.36 \pm 0.91$ & $22.0 \pm 8.6$ \\
\hline I-9 & $>40.7$ & $5.32 \pm 1.02$ & $40.7 \pm 17.4$ \\
\hline Etravirine & $0.01 \pm 0.001$ & $\mathrm{ND}^{\mathrm{c}}$ & $\mathrm{ND}$ \\
\hline Rilpivirine & $0.01 \pm 0.001$ & $\mathrm{ND}$ & $\mathrm{ND}$ \\
\hline
\end{tabular}

${ }^{a} \mathrm{EC}_{50}$ : concentration of compound required to achieve $50 \%$ protection of MT- 4 cell cultures against HIV1-induced cytotoxicity, as determined by the MTT method. 
${ }^{b} \mathrm{CC}_{50}$ : concentration required to reduce the viability of mock-infected cell cultures by $50 \%$, as determined by the MTT method.

${ }^{\mathrm{c}}$ Not determined.

\subsubsection{Mass spectrometry}

The molecular weights of complexes of I-7 and Y181C HIV-1 RT were determined by matrixassisted laser desorption/ionization-time of flight (MALDI-TOF) mass spectrometry. In these experiments the mutant Y181C RT (at around $30 \mu \mathrm{M}$ ) was incubated for 1 hour at room temperature in the presence of $\mathbf{I - 7}$ at concentrations as high as $1.3 \mathrm{mM}$. The results shown in Fig. 4 are consistent with the formation of covalent complexes when the mutant enzyme is incubated with the inhibitor. Peaks at $\mathrm{m} / \mathrm{z}$ values of 65,947 and 51,634 were observed in determinations made with the mutant RT alone and correspond to subunits p66 and p51, respectively (Fig. 4A). Peaks of 33,056 and 25,868 are consistent with the expected two-fold mass-to-charge reduction. In contrast, at high concentrations of the inhibitor (i.e., $1.3 \mathrm{mM}$ ), peaks shifted to 66,714-67,126 Da for p66 and 52,244 for p51 (Fig. 4C). These mass increases were consistent with the incorporation of 2-3 indolylarylsulfones in p66 and 2 in p51. Each Y181C RT subunit contains three cysteine residues (Cys38, Cys 181 and Cys280). Interestingly, in assays carried out with $50 \mu \mathrm{M} \mathrm{I-7,} \mathrm{we} \mathrm{observed} \mathrm{that}$ the molecular mass of p51 remains unaffected (51,529 Da), although an increase of $364 \mathrm{Da}$ was observed in p66 (molecular mass 66,311 Da) (Fig. 4B). These results were compatible with the covalent modification of Cys 181 in NNRTI binding site of the Y181C mutant. In addition, the likely modification of additional Cys residues in the RT when higher concentrations of I-7 are used is consistent with its relatively high cytotoxicity, which seems to be prone to off-target labeling of viral and cellular proteins. 

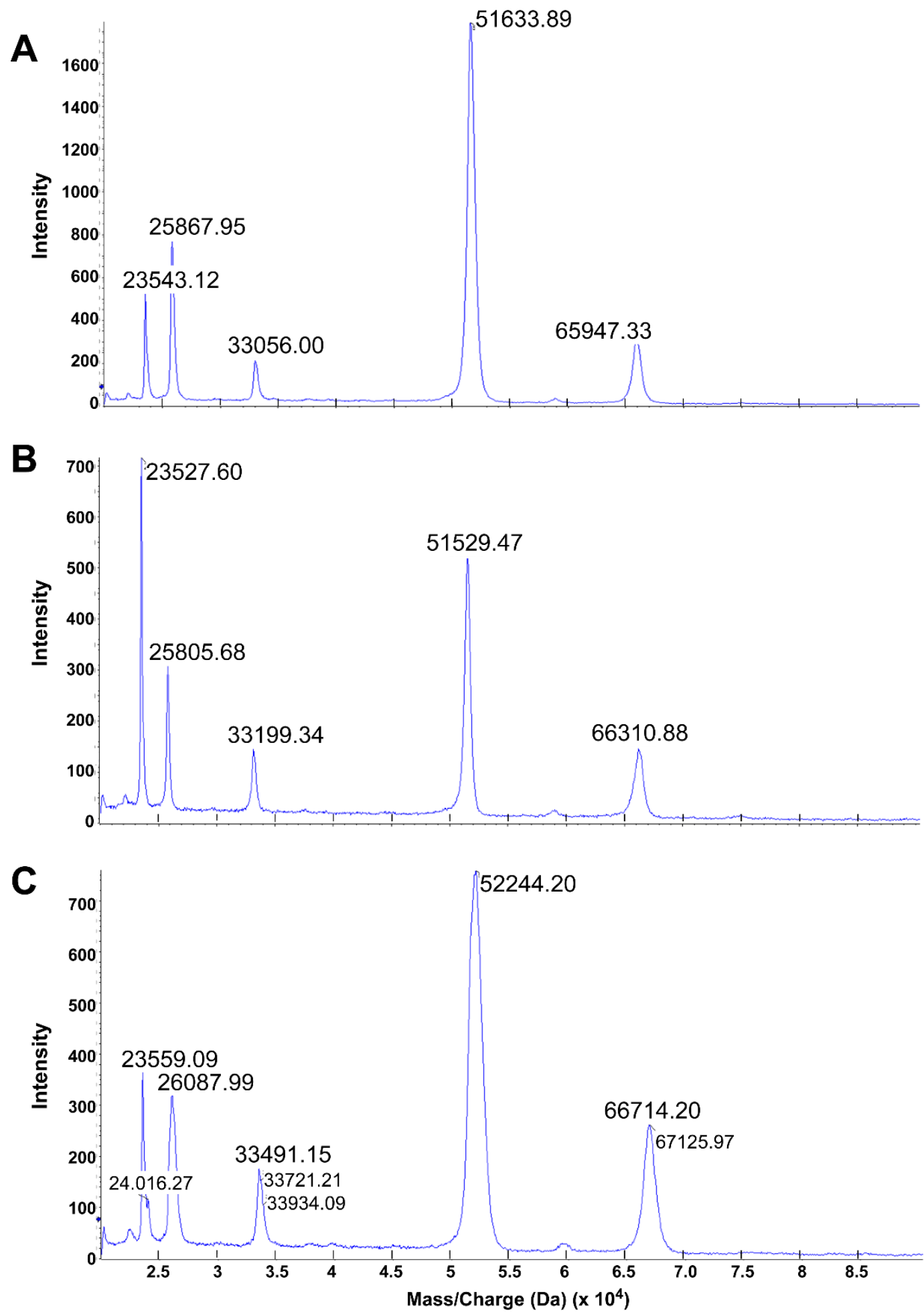

Fig. 4. Molecular weight determinations using MALDI-TOF mass spectrometry. (A) Y181C RT (without inhibitor). (B) Y181C RT incubated in the presence of I-7 $(50 \mu \mathrm{M})$. (C) Y181C RT incubated in the presence of $\mathbf{I}-\mathbf{7}(1.3 \mathrm{mM})$. 
Covalent modification of Cys181 was further demonstrated after trypsin digestion of the treated Y181C RT, and subsequent analysis by liquid chromatography-electrospray ionization tandem mass spectrometry (LC-ESI MS/MS). Before trypsin hydrolysis, cysteine residues were blocked with chloroacetamide. The LC-ESI MS/MS analysis of the Y181C RT treated with I-7 for 1 hour at $50 \mu \mathrm{M}$ revealed the presence of a tryptic peptide QNPDIVICQYMDDLYVGSDLEIGQHRW with an expected molecular mass of 3,496.39 Da, consistent with the presence of I-7 (477.35 Da) bound to Cys181 (Fig. 5A). In the same sample, we detected a carbamidomethylated derivative of the Cys-containing peptide with a molecular mass of 3,077.42 Da. For all modified peptides, scores were relatively high and significant (Fig. 5A). The protein sequence coverages obtained with treated and untreated Y181C RTs were 82 and $83 \%$, respectively, and all Cys-containing peptides were identified in the analysis (Supplementary Tables S1 and S2). However, the peptide of 3,496.39 Da mentioned above was the only one identified whose molecular mass was consistent with the presence of $\mathbf{I - 7}$ bound to Cys181. The identification of this covalently-modified peptide was further supported by MS/MS fragmentation patterns leading to the recognition of the internal sequence DDLYVGSDLEIG (Fig. 5B). 


\section{B}

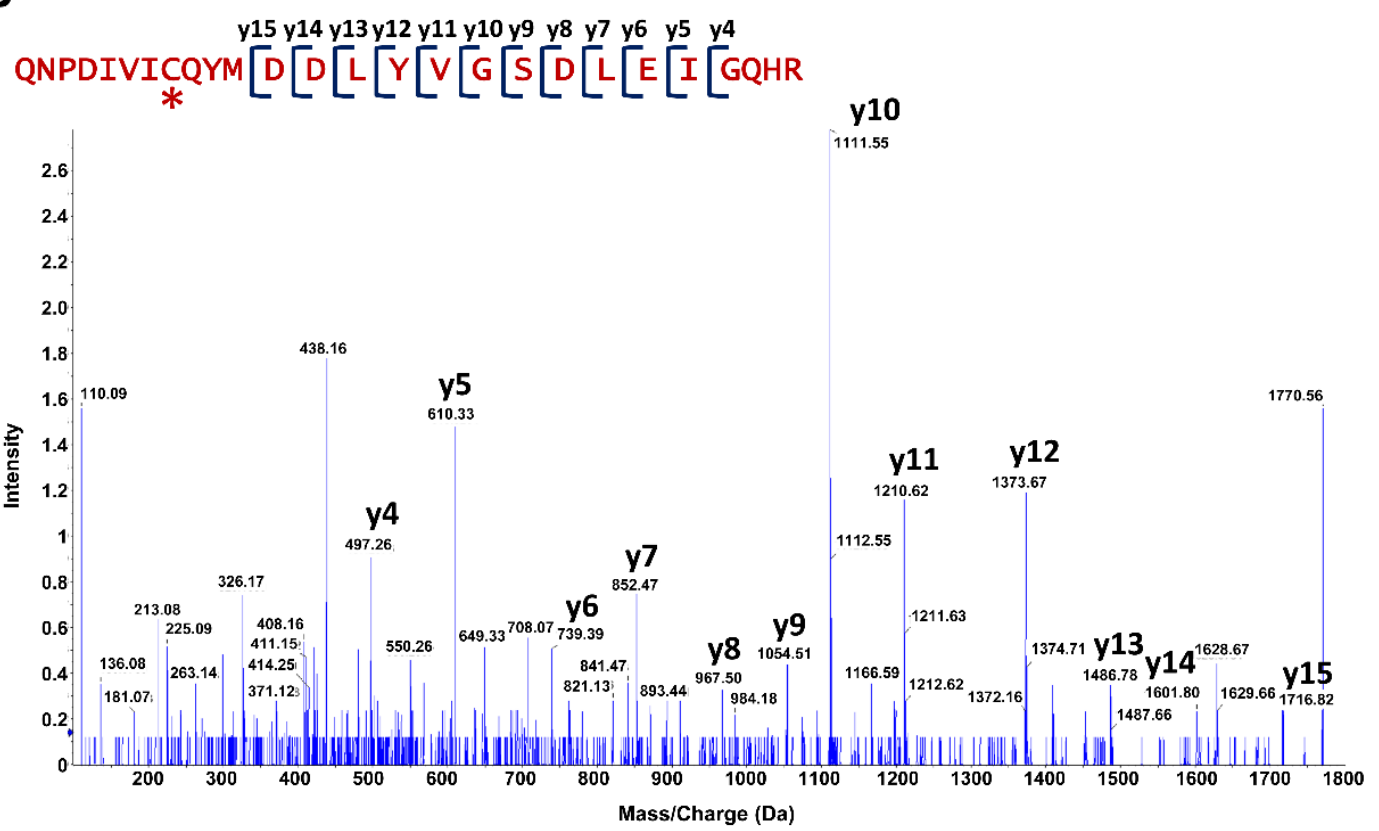

Fig. 5. Covalent modification of Cys181 by I-7. (A) Mascot software analysis of LC-ESI MS/MS data obtained for the Y181C RT mutant after treatment with I-7 for 1 hour at $50 \mu \mathrm{M}$, followed by blocking of available Cys residues with chloroacetamide. Modified Cys-containing peptides are shown. Peptide numbering is shifted three residues due to the addition of three residues (MNS) at the N-terminus of the recombinant RT. (B) MS/MS fragmentation pattern for QNPDIVICQYMDDLYVGSDLEIGQHRW covalently modified with I-7. Peptides y4 to y15 were positively identified based on theoretical assignments in the MS spectrum (Supplementary Table S3).

\subsubsection{Molecular modeling}

In order to gain further insight into the preferred binding mode of the tested compounds and rationalize results of the SAR analysis, molecular models of I-7 bound to WT and Y181C mutant HIV-1 RT were obtained. According to the model of the Y181C mutant, stabilization of I-7 in the NNRTI binding pocket can be achieved through interactions with the side chains of Phe227 and Pro236, as well as a hydrogen bond between the sulfone group of I-7 and Lys101 (Fig. 6). The predicted conformation of I-7 is compatible with the formation of a covalent bond between the ethylene sulfonamide reactive group and the side chain of Cys181, explaining the superior activity 
of I-7 against the Y181C RT as compared with the WT enzyme. As for the binding mode of I-7 in the WT RT, Fig. 6C shows the results of the docking experiment showing the highest-score model predicted by the molecular modeling software. As illustrated in the figure, I-7 cannot maintain an active conformation due to the loss of hydrogen bonds with Lys101, in agreement with its poor inhibitory activity of WT HIV-1 RT in enzymatic assays. 

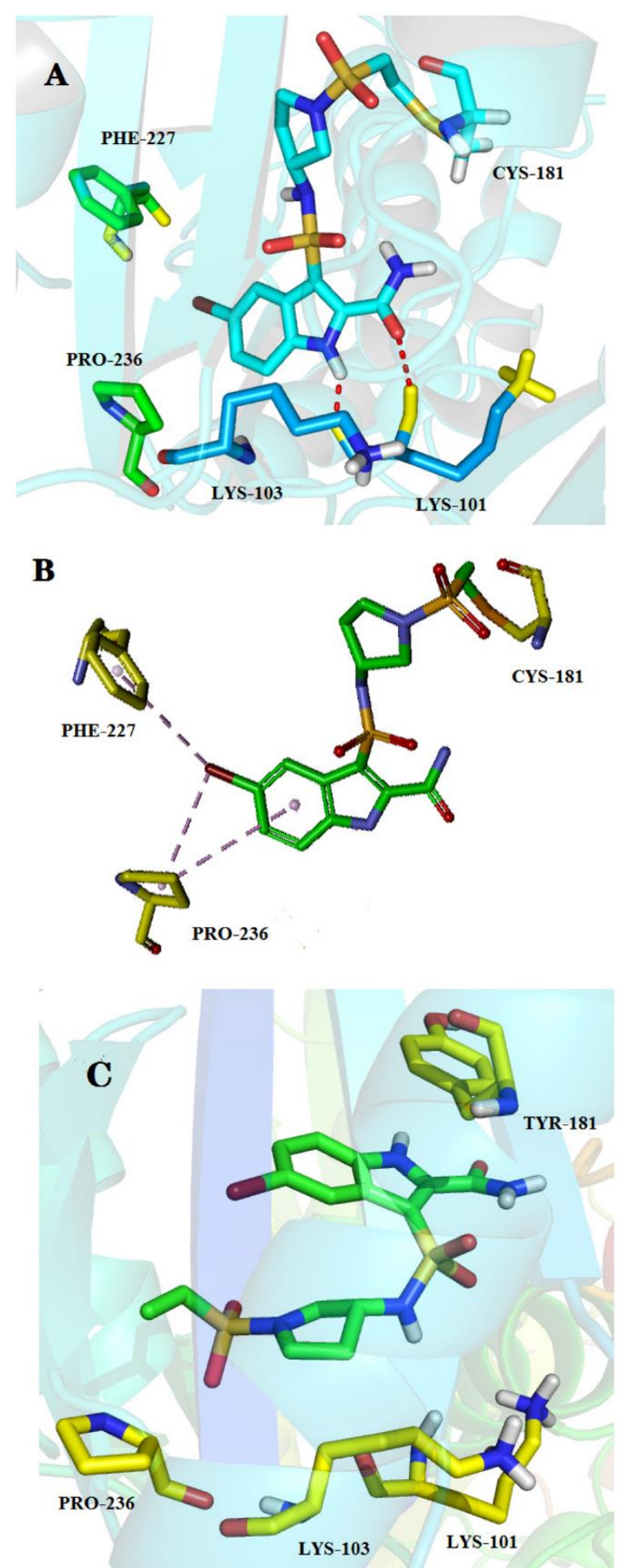

Fig. 6. Predicted binding modes of I-7 in the NNRTI binding pocket of HIV-1 RT. (A, B) Docking of I-7 in the allosteric site of HIV-1 Y181C RT (PDB code: 3DRR) using Discovery Studio 3.5, showing hydrogen bonds (dashed lines in red) with the polypeptide backbone of Lys101 (A) and additional interactions with the side chains of Phe227 and Pro236 (B). (C) Docking of I-7 in the allosteric site of HIV-1 WT RT (PDB code: 2RF2) using Sybyl-X 2.0. Non-polar hydrogen atoms are omitted for clarity. 


\section{Conclusions}

How to overcome drug resistance has always been one of the great challenges in clinical treatment of HIV-1. In this paper, we reported the design, synthesis and biological evaluation of a novel series of indolylarylsulfones as selective HIV-1 Y181C RT inhibitors, among which I-7 and I-9 demonstrated higher selectivity against mutant Y181C RT than against the WT HIV-1 $1_{\mathrm{BH} 10}$ RT. Mass spectrometry determinations were consistent with the covalent modification of Y181C RT in the NNRTI binding site of p66. However, experimental evidence reveals the presence of additional targets in the RT, if the concentration of I-7 is increased. The poor selectivity of the reaction under these conditions could explain the high cytotoxicity observed with most of the synthesized compounds, attributed to off-target labeling of viral and cellular proteins. However, our results indicated that selective labeling can be achieved by controlling the incubation time of the reaction and concentration of the covalent agent. Future efforts should be focused on avoiding off-target inhibition, probably by using reactive groups (warheads) with lower activity.

\section{Experimental section}

\subsection{Chemistry}

Mass spectrometry was performed on an API 4000 triple quadrupole mass spectrometer (Applied Biosystems/MDS Sciex, Concord, ON, Canada). ${ }^{1} \mathrm{H}$ NMR and ${ }^{13} \mathrm{C}$ NMR spectra were recorded on a Bruker AV-400 spectrometer (Bruker BioSpin, Switzerland), using solvents as indicated $\left(\right.$ DMSO- $\left.\mathrm{d}_{6}\right)$. Chemical shifts were reported in $\delta$ values $(\mathrm{ppm})$ with tetramethylsilane as the internal reference, and $\mathbf{J}$ values were reported in hertz $(\mathrm{Hz})$. Melting points $(\mathrm{mp}$ ) were determined on a micromelting point apparatus (Tian Jin Analytical Instrument Factory, Nankai, Tianjin, China). Flash column chromatography was performed on columns packed with silica gel 60 (200-300 mesh) (Qingdao waves silica gel desiccant co., Ltd, Qingdao, China). Thin layer chromatography was performed on pre-coated HUANGHAI@ HSGF254, 0.15-0.2 mm TLC-plates (Yantai Jiangyou Silica Gel Development Co., Ltd., Yantai, Shandong, China). The key reactants were purchased from Bide Pharmatech Co. Ltd.

\subsubsection{Ethyl 5-bromo-3-(chlorosulfonyl)-1H-indole-2-carboxylate (3)}

Synthesis was initiated by adding acetic anhydride $(28 \mathrm{~mL})$ to the starting material (1) $(7 \mathrm{~g}$, 
$0.026 \mathrm{~mol}$ ) at room temperature. The reaction mixture was subsequently cooled to $0^{\circ} \mathrm{C}$, and sulphuric acid $(7 \mathrm{~mL})$ was added drop wise. The reaction was stirred for 12-15 hours at room temperature to ensure consumption of starting material. The solid was then filtered by suction filtration to get crude compound 5-bromo-2-(ethoxycarbonyl)-1H-indole-3-sulfonic acid (2), which was taken to the next step without further purification.

Compound $2(8 \mathrm{~g}, 0.023 \mathrm{~mol})$ was suspended in dichloromethane $(110 \mathrm{~mL})$ to which catalytic amount of DMF (3.6 mL) was added and the mixture was stirred at room temperature till a clear solution was obtained. Oxalyl chloride $(9.8 \mathrm{~mL})$ in dichloromethane $(50 \mathrm{~mL})$ was added to the reaction mixture drop wise over a period of 15-20 min at room temperature. The reaction mixture was heated at $40{ }^{\circ} \mathrm{C}$ with stirring for 2-3 $\mathrm{h}$. After evaporating a portion of dichloromethane, the reaction mixture is cooled to $0-5{ }^{\circ} \mathrm{C}$ and maintained for $1-1.5 \mathrm{~h}$. The crude compound obtained was filtered, washed with chilled dichloromethane $(40 \mathrm{~mL})$ and dried at $40-45^{\circ} \mathrm{C}$ to give compound 3 as a white solid. Yield 41\%, ESI-MS: m/z $365.3(\mathrm{M}+1), 367.3(\mathrm{M}+1), \mathrm{C}_{11} \mathrm{H}_{9} \mathrm{BrClNO}_{4} \mathrm{~S}$ (366.62).

\subsubsection{Synthesis of intermediate 4}

To a solution of ethyl 5-bromo-3-(chlorosulfonyl)-1H-indole-2-carboxylate (Compound 3, 2.5 $\mathrm{g}, 6.8 \mathrm{mmol})$ in dichloromethane $(40 \mathrm{~mL})$, triethylamine $(1.9 \mathrm{~mL})$ and alkylamine $(7.5 \mathrm{mmol})$ were added successively at $0{ }^{\circ} \mathrm{C}$. The reaction was then stirred overnight at room temperature. On completion of the reaction, the reaction was quenched with water and the mixture was extracted with dichloromethane. The organic phase was shaken with saturated solution of sodium hydrogen carbonate and then brine, dried over anhydrous $\mathrm{MgSO}_{4}$, filtered and concentrated under reduced pressure. Purification on silica gel (ethyl acetate: petroleum $(\mathrm{EA}: \mathrm{PE})=1: 3$ ) gave intermediate $\mathbf{4}$ as a white solid.

(R)-ethyl-5-bromo-3-((3-((tert-butoxycarbonyl)amino)pyrrolidin-1-yl)sulfonyl)-1H-indole-2carboxylate (4-1): white solid, yield: 39\%. mp: 183-185 ${ }^{\circ} \mathrm{C} .{ }^{1} \mathrm{H}$ NMR (400 MHz, DMSO-d 6 ) $\delta: 13.09$ (s, 1H), $8.14(\mathrm{~d}, J=1.2 \mathrm{~Hz}, 1 \mathrm{H}), 7.55(\mathrm{~d}, J=8.5 \mathrm{~Hz}, 1 \mathrm{H}), 7.51(\mathrm{~d}, J=8.8 \mathrm{~Hz}, 1 \mathrm{H}), 7.00(\mathrm{~d}, J=6.1$ $\mathrm{Hz}, 1 \mathrm{H}), 4.40(\mathrm{q}, J=7.1 \mathrm{~Hz}, 2 \mathrm{H}), 3.89-3.85(\mathrm{~m}, 1 \mathrm{H}), 3.51-3.38(\mathrm{~m}, 2 \mathrm{H}), 3.33-3.27(\mathrm{~m}, 1 \mathrm{H}), 3.14-$ $3.11(\mathrm{~m}, 1 \mathrm{H}), 1.94(\mathrm{td}, J=13.8,7.1 \mathrm{~Hz}, 1 \mathrm{H}), 1.66(\mathrm{td}, J=13.2,6.2 \mathrm{~Hz}, 1 \mathrm{H}), 1.36(\mathrm{t}, J=7.1 \mathrm{~Hz}$, 3H), 1.32 (s, 9H). ${ }^{13} \mathrm{C}$ NMR (100 MHz, DMSO-d $) \delta: 159.89$, 155.54, 133.84, 130.55, 128.44, $127.72,123.92,115.73,112.58,78.39,62.57,53.37,50.21,46.50,30.73,28.58,14.32$. ESI-MS: $\mathrm{m} / \mathrm{z} 518.5(\mathrm{M}+\mathrm{H}), 533.4\left(\mathrm{M}+\mathrm{NH}_{3}\right), 535.3\left(\mathrm{M}+\mathrm{NH}_{3}\right), 540.5(\mathrm{M}+\mathrm{Na}), \mathrm{C}_{20} \mathrm{H}_{26} \mathrm{BrN}_{3} \mathrm{O}_{6} \mathrm{~S}(516.41)$. 
Ethyl-5-bromo-3-((4-((tert-butoxycarbonyl)amino)piperidin-1-yl)sulfonyl)-1H-indol-2-

carboxylate (4-3): White solid, yield: $45 \%$. mp: $229-231^{\circ} \mathrm{C} .{ }^{1} \mathrm{H}$ NMR (400 MHz, DMSO-d 6 ) $\delta: 12.97$ (s, 1H), $8.25(\mathrm{~s}, 1 \mathrm{H}), 7.52(\mathrm{~s}, 2 \mathrm{H}), 7.27(\mathrm{~d}, J=7.6 \mathrm{~Hz}, 1 \mathrm{H}), 4.45(\mathrm{q}, J=7.1 \mathrm{~Hz}, 2 \mathrm{H}), 3.71(\mathrm{~d}, J=$ $13.2 \mathrm{~Hz}, 2 \mathrm{H}), 3.31-3.27(\mathrm{~m}, 1 \mathrm{H}), 2.72(\mathrm{~d}, J=6.9 \mathrm{~Hz}, 2 \mathrm{H}), 1.57-1.53(\mathrm{~m}, 2 \mathrm{H}), 1.38(\mathrm{t}, J=7.1 \mathrm{~Hz}$, 3H), $1.35(\mathrm{~s}, 9 \mathrm{H}), 1.31-1.21(\mathrm{~m}, 2 \mathrm{H})$. ESI-MS: m/z $532.5(\mathrm{M}+\mathrm{H}), 549.5\left(\mathrm{M}+\mathrm{NH}_{3}\right), 552.5(\mathrm{M}+\mathrm{Na})$, $\mathrm{C}_{21} \mathrm{H}_{28} \mathrm{BrN}_{3} \mathrm{O}_{6} \mathrm{~S}(530.43)$

(R)-ethyl-5-bromo-3-(N-(1-(tert-butoxycarbonyl)piperidin-3-yl)sulfamoyl)-1H-indole-2carboxylate (4-4): White solid, yield: $35 \%$. mp: $185-187^{\circ} \mathrm{C} .{ }^{1} \mathrm{H}$ NMR (400 MHz, DMSO- $\left.\mathrm{d}_{6}\right) \delta$ : $13.03(\mathrm{~s}, 1 \mathrm{H}), 8.24(\mathrm{~s}, 1 \mathrm{H}), 7.52$ (s, 2H), 7.30 (d, $J=7.6 \mathrm{~Hz}, 1 \mathrm{H}), 4.43$ (q, $J=7.1 \mathrm{~Hz}, 2 \mathrm{H}), 3.67$ (d, $J=12.8 \mathrm{~Hz}, 1 \mathrm{H}), 3.59(\mathrm{~d}, J=11.3 \mathrm{~Hz}, 1 \mathrm{H}), 3.13(\mathrm{~s}, 1 \mathrm{H}), 2.66(\mathrm{~d}, J=13.4 \mathrm{~Hz}, 2 \mathrm{H}), 1.63(\mathrm{~s}, 1 \mathrm{H})$, $1.53(\mathrm{~d}, J=13.0 \mathrm{~Hz}, 1 \mathrm{H}), 1.37(\mathrm{t}, J=7.1 \mathrm{~Hz}, 3 \mathrm{H}), 1.24(\mathrm{~s}, 9 \mathrm{H}) .{ }^{13} \mathrm{C}$ NMR $(100 \mathrm{MHz}$, DMSO-d 6$)$ $\delta: 160.14,154.14,133.83,128.84,128.59,126.65,123.86,117.89,115.75,115.60,79.10,62.61$ 49.84, 31.00, 28.31, 23.80, 14.46. ESI-MS: m/z 530.3 (M+H), 532.3(M+H), $552.4(\mathrm{M}+\mathrm{Na}), 554.1$ $(\mathrm{M}+\mathrm{Na}), \mathrm{C}_{21} \mathrm{H}_{28} \mathrm{BrN}_{3} \mathrm{O}_{6} \mathrm{~S}$ (530.43). (S)-ethyl-5-bromo-3-(N-(1-(tert-butoxycarbonyl)pyrrolidin-3yl)sulfamoyl)-1H-indole-2-carboxylate(4-5): White solid, yield: $43 \%$. mp: 118-120 ${ }^{\circ} \mathrm{C}$. ESI-MS: $\mathrm{m} / \mathrm{z} 516.5(\mathrm{M}+\mathrm{H}), 535.3\left(\mathrm{M}+\mathrm{NH}_{3}\right), 540.4(\mathrm{M}+\mathrm{Na}), \mathrm{C}_{20} \mathrm{H}_{26} \mathrm{BrN}_{3} \mathrm{O}_{6} \mathrm{~S}(516.41)$.

4.1.3 Synthesis of Intermediate 5

Intermediate $4(0.2 \mathrm{~g})$ was dissolved in a saturated solution of ammonia in methanol $(10 \mathrm{~mL})$ in a sealed tube at $70{ }^{\circ} \mathrm{C}$ overnight. After cooling, the reaction mixture was poured on ice water, stirred for $15 \mathrm{~min}$, and extracted with ethyl acetate. The organic layer was washed with brine and dried and the solvent evaporated to afford a residue which was purified on silica gel column chromatography (methanol-dichloromethane1:30 as eluent) to give intermediate $\mathbf{5}$.

(R)-tert-butyl-(1-((5-bromo-2-carbamoyl-1H-indol-3-yl)sulfonyl)pyrrolidin-3-yl)carbamate (5-1): White powder, yield: $77 \%, \mathrm{mp}: 210-211^{\circ} \mathrm{C} .{ }^{1} \mathrm{H}$ NMR (400 MHz, DMSO- $\left.d_{6}\right) \delta: 12.92(\mathrm{~s}$, $1 \mathrm{H}), 8.37(\mathrm{~s}, 1 \mathrm{H}), 8.21(\mathrm{~s}, 1 \mathrm{H}), 8.09(\mathrm{~d}, J=1.5 \mathrm{~Hz}, 1 \mathrm{H}), 7.53-7.45(\mathrm{~m}, 2 \mathrm{H}), 7.02(\mathrm{~d}, J=6.1 \mathrm{~Hz}, 1 \mathrm{H})$, $3.87(\mathrm{~d}, J=5.6 \mathrm{~Hz}, 1 \mathrm{H}), 3.36(\mathrm{~d}, J=9.4 \mathrm{~Hz}, 1 \mathrm{H}), 3.31-3.27(\mathrm{~m}, 1 \mathrm{H}), 3.22-3.20(\mathrm{~m}, 1 \mathrm{H}), 2.99-2.95$ $(\mathrm{m}, 1 \mathrm{H}), 1.92(\mathrm{td}, J=13.8,7.1 \mathrm{~Hz}, 1 \mathrm{H}), 1.63(\mathrm{td}, J=13.0,6.1 \mathrm{~Hz}, 1 \mathrm{H}), 1.32(\mathrm{~s}, 9 \mathrm{H}) .{ }^{13} \mathrm{C}$ NMR $(100$ MHz, DMSO-d 6 ) $\delta: 160.99,155.49,135.71,133.29,127.89,127.72,123.42,115.58,115.44,107.31$, 78.45, 53.30, 49.07, 46.46, 30.69, 28.59. ESI-MS: m/z 511.0 (M+Na), $\mathrm{C}_{18} \mathrm{H}_{23} \mathrm{BrN}_{4} \mathrm{O}_{5} \mathrm{~S}$ (487.37). 
(5-2): White solid, yield: 78\%, mp: $121-123^{\circ} \mathrm{C} .{ }^{1} \mathrm{H}$ NMR (400 MHz, DMSO- $\left.d_{6}\right) \delta: 12.76(\mathrm{~s}, 1 \mathrm{H})$, $8.39(\mathrm{~s}, 1 \mathrm{H}), 8.20(\mathrm{~s}, 1 \mathrm{H}), 8.16(\mathrm{~s}, 1 \mathrm{H}), 8.05(\mathrm{~d}, J=6.7 \mathrm{~Hz}, 1 \mathrm{H}), 7.52-7.45(\mathrm{~m}, 2 \mathrm{H}), 3.74-3.72(\mathrm{~m}$, 1H), 3.72-3.17 (m,2H), 3.14-3.07 (m, 1H), 2.94-2.87 (m, 1H), 1.89-1.81 (m, 1H), 1.73-1.60 (m, 1H), 1.3 (s, 9H). ${ }^{13} \mathrm{C}$ NMR (100 MHz, DMSO-d 6 ) $\delta: 161.11,153.73,134.91,133.27,127.69,126.68$, 123.43, 115.43, 115.19, 112.26, 78.75, 52.57, 49.07, 43.75, 30.91, 28.51. ESI-MS: m/z 409.1 $(\mathrm{M}+\mathrm{Na}), 511.1(\mathrm{M}+\mathrm{Na}), \mathrm{C}_{18} \mathrm{H}_{23} \mathrm{BrN}_{4} \mathrm{O}_{5} \mathrm{~S}$ (487.37).

tert-butyl-(1-((5-bromo-2-carbamoyl-1H-indol-3-yl)sulfonyl)piperidin-4-yl)carbamate (5-3):

White solid, yield: $82 \%$, mp: $242-244^{\circ} \mathrm{C} .{ }^{1} \mathrm{H}$ NMR (400 MHz, DMSO- $\left.d_{6}\right) \delta: 12.94$ (s, 1H), 8.28 (s, 1H), $8.20(\mathrm{~s}, 1 \mathrm{H}), 8.04(\mathrm{~d}, J=1.5 \mathrm{~Hz}, 1 \mathrm{H}), 7.53-7.46(\mathrm{~m}, 2 \mathrm{H}), 6.84(\mathrm{~d}, J=7.2 \mathrm{~Hz}, 1 \mathrm{H}), 3.48-3.45$ (m, 2H), $3.25(\mathrm{~d}, J=6.5 \mathrm{~Hz}, 1 \mathrm{H}), 2.59-3.54(\mathrm{~m}, 2 \mathrm{H}), 1.76(\mathrm{~d}, J=10.4 \mathrm{~Hz}, 2 \mathrm{H}), 1.45-1.39(\mathrm{~m}, 2 \mathrm{H})$, 1.34 (s, 9H). ${ }^{13} \mathrm{C}$ NMR (100 MHz, DMSO-d $) \delta: 160.95,155.24,135.97,133.31,127.71,127.54$, 123.35, 115.62, 115.44, 107.09, 78.08, 46.19, 44.73, 31.12, 28.67. ESI-MS: m/z 523.1 (M+Na), $525.1(\mathrm{M}+\mathrm{Na}), \mathrm{C}_{19} \mathrm{H}_{25} \mathrm{BrN}_{4} \mathrm{O}_{5} \mathrm{~S}$ (501.39).

(R)-tert-butyl-3-(5-bromo-2-carbamoyl-1H-indole-3-sulfonamido)piperidine-1-carboxylate (5-4): White solid, yield: 99\%, mp: 107-109 ${ }^{\circ} \mathrm{C} .{ }^{1} \mathrm{H}$ NMR (400 MHz, DMSO- $\left.d_{6}\right) \delta: 12.70(\mathrm{~s}, 1 \mathrm{H})$, $8.38(\mathrm{~s}, 1 \mathrm{H}), 8.19(\mathrm{~s}, 1 \mathrm{H}), 8.18(\mathrm{~s}, 1 \mathrm{H}), 7.94(\mathrm{~d}, J=6.7 \mathrm{~Hz}, 1 \mathrm{H}), 7.51-7.44(\mathrm{~m}, 2 \mathrm{H}), 3.57(\mathrm{~d}, J=13.3$ $\mathrm{Hz}, 2 \mathrm{H}), 2.99$ (s, 1H), 2.69-2.63 (m, 2H), 1.60-1.52 (m, 2H), 1.27 (s, 9H), 1.17 (t, $J=7.1 \mathrm{~Hz}, 2 \mathrm{H})$. ${ }^{13} \mathrm{C}$ NMR (100 MHz, DMSO-d 6 ) $\delta: 161.07,154.15,134.19,133.25,127.67,126.90,123.42,115.50$, 115.17, 113.24, 79.17, 60.22, 49.60, 49.07, 28.36, 21.23, 14.55. ESI-MS: m/z 523.1 (M+Na), 525.1 $(\mathrm{M}+\mathrm{Na}), \quad \mathrm{C}_{19} \mathrm{H}_{25} \mathrm{BrN}_{4} \mathrm{O}_{5} \mathrm{~S} \quad$ (501.39). (S)-tert-butyl-3-(5-bromo-2-carbamoyl-1H-indole-3sulfonamido)pyrrolidine-1-carboxylate (5-5): White solid, yield: $88.3 \%, \mathrm{mp}: 155-157^{\circ} \mathrm{C}$.

\subsubsection{Synthesis of intermediate 6}

Trifluoroacetic acid $(1 \mathrm{~mL})$ was added dropwise under stirring to a solution of intermediate $\mathrm{E}$ $(0.5 \mathrm{~g})$ in $\mathrm{CH}_{2} \mathrm{Cl}_{2}(4 \mathrm{~mL})$ at room temperature and stirred for $4 \mathrm{~h}$. To the reaction mixture was added water and neutralized with $2 \mathrm{~N} \mathrm{NaOH}$ to $\mathrm{pH} 8$, and the organic layer was separated and dried over anhydrous $\mathrm{MgSO}_{4}$, filtered and concentrated under reduced pressure to give the crude product 6 .

(R)-3-((3-aminopyrrolidin-1-yl)sulfonyl)-5-bromo-1H-indole-2-carboxamide (6-1): White solid, ESI-MS: m/z $387.0(\mathrm{M}+\mathrm{H}), 389.0(\mathrm{M}+\mathrm{H}), \mathrm{C}_{13} \mathrm{H}_{15} \mathrm{BrN}_{4} \mathrm{O}_{3} \mathrm{~S}$ (387.25).

(R)-5-bromo-3-(N-(pyrrolidin-3-yl)sulfamoyl)-1H-indole-2-carboxamide (6-2): Brown solid, ESI-MS: m/z $387.4(\mathrm{M}+\mathrm{H}), 389.4(\mathrm{M}+\mathrm{H}), \mathrm{C}_{13} \mathrm{H}_{15} \mathrm{BrN}_{4} \mathrm{O}_{3} \mathrm{~S}$ (387.25). 
(R)-5-bromo-3-(N-(piperidin-3-yl)sulfamoyl)-1H-indole-2-carboxamide (6-4): White solid, ESI-MS: m/z 401.0(M+H), 403.0(M+H), $\mathrm{C}_{14} \mathrm{H}_{17} \mathrm{BrN}_{4} \mathrm{O}_{3} \mathrm{~S}(401.28)$.

4.1.5 Synthesis of target compounds

A solution of the acryl chloride $(0.13 \mathrm{~g}, 0.71 \mathrm{mmol})$ in tetrahydrofuran was slowly added to a mixture solution of acryl chloride $(1.2 \mathrm{eq})$ and $\mathrm{Et}_{3} \mathrm{~N}(1.5 \mathrm{eq})$ in dry tetrahydrofuran at $-20^{\circ} \mathrm{C}$. The mixture was stirred at room temperature until the raw materials are consumed by TLC detection. The solvent was removed under reduced pressure, and the residue was purified by column chromatography on silica gel using methanol-dichloromethane 1:30 as eluent to give target compound.

(R)-3-((3-acrylamidopyrrolidin-1-yl)sulfonyl)-5-bromo-1H-indole-2-carboxamide (I-1)

White crystal, yield: $42 \%$. mp: $216-217^{\circ} \mathrm{C} .{ }^{1} \mathrm{H}$ NMR (400 MHz, DMSO-d 6$) \delta: 12.94(\mathrm{~s}, 1 \mathrm{H})$, $8.37(\mathrm{~s}, 1 \mathrm{H}), 8.23(\mathrm{~s}, 1 \mathrm{H}), 8.22(\mathrm{~s}, 1 \mathrm{H}), 8.08(\mathrm{~d}, J=1.5 \mathrm{~Hz}, 1 \mathrm{H}), 7.53-7.45(\mathrm{~m}, 2 \mathrm{H}), 6.05-6.03(\mathrm{~m}$, 2H), $5.54(\mathrm{dd}, J=8.7,3.6 \mathrm{~Hz}, 1 \mathrm{H}), 4.20-4.12(\mathrm{~m}, 1 \mathrm{H}), 3.38-3.34(\mathrm{~m}, 2 \mathrm{H}), 3.24-3.18(\mathrm{~m}, 1 \mathrm{H}), 3.07-$ $3.04(\mathrm{~m}, 1 \mathrm{H}), 2.01(\mathrm{td}, J=13.8,7.1 \mathrm{~Hz}, 1 \mathrm{H}), 1.69(\mathrm{td}, J=13.1,6.7 \mathrm{~Hz}, 1 \mathrm{H}) .{ }^{13} \mathrm{C} \mathrm{NMR}(100 \mathrm{MHz}$, DMSO-d 6 ) $\delta: 164.90,161.03,135.86,133.28,131.56,127.85,127.74,125.96,123.38,115.59$, 115.50, 107.13, 49.07, 48.91, 46.49, 30.74. ESI-MS: $m / z \quad 441.4(\mathrm{M}+\mathrm{H}), 443.5(\mathrm{M}+\mathrm{H}), 458.4$ $\left(\mathrm{M}+\mathrm{NH}_{3}\right), 460.4\left(\mathrm{M}+\mathrm{NH}_{3}\right), 465.3(\mathrm{M}+\mathrm{Na}), \mathrm{C}_{16} \mathrm{H}_{17} \mathrm{BrN}_{4} \mathrm{O}_{4} \mathrm{~S}(441.30)$.

(R)-3-(N-(1-acryloylpyrrolidin-3-yl)sulfamoyl)-5-bromo-1H-indole-2-carboxamide (I-2)

White crystal, yield: $34 \%$ mp: $240-242{ }^{\circ} \mathrm{C} .{ }^{1} \mathrm{H}$ NMR (400 MHz, DMSO-d $) \delta: 12.77$ (s, 1H), $8.39(\mathrm{~s}, 1 \mathrm{H}), 8.20(\mathrm{~s}, 1 \mathrm{H}), 8.16(\mathrm{~s}, 1 \mathrm{H}), 8.09(\mathrm{dd}, J=11.7,6.4 \mathrm{~Hz}, 1 \mathrm{H}), 7.53-7.45(\mathrm{~m}, 2 \mathrm{H}), 6.53-$ 6.31(m, 1H), 6.10-6.05 (m, 1H), 5.65-5.58 (m, 1H), 3.85-3.74 (m, 1H), 3.62-3.53 (m, 1H), 3.49$3.35(\mathrm{~m}, 1 \mathrm{H}), 3.32-3.25(\mathrm{~m}, 1 \mathrm{H}), 3.23-3.12(\mathrm{~m}, 1 \mathrm{H}), 1.99-1.61(\mathrm{~m}, 2 \mathrm{H}) .{ }^{13} \mathrm{C} \mathrm{NMR}(100 \mathrm{MHz}$, DMSO-d 6 ) $\delta: 163.92,161.13,134.99,133.29,129.80,129.57,127.65,127.25,126.69,123.42$, 115.20, 112.14, 51.82, 51.28, 44.39, 31.97. ESI-MS: $m / z 441.3(\mathrm{M}+\mathrm{H}), 443.3(\mathrm{M}+\mathrm{H}), 463.4(\mathrm{M}+\mathrm{Na})$, $465.3(\mathrm{M}+\mathrm{Na}), \mathrm{C}_{16} \mathrm{H}_{17} \mathrm{BrN}_{4} \mathrm{O}_{4} \mathrm{~S}(441.30)$.

3-((4-acrylamidopiperidin-1-yl)sulfonyl)-5-bromo-1H-indole-2-carboxamide (I-3)

White crystal, yield: $43 \%$. Decompose at $267^{\circ} \mathrm{C} .{ }^{1} \mathrm{H}$ NMR (400 MHz, DMSO-d 6 ) $\delta$ : 12.95 (s, 1H), $8.28(\mathrm{~s}, 1 \mathrm{H}), 8.20(\mathrm{~s}, 1 \mathrm{H}), 8.05(\mathrm{~s}, 1 \mathrm{H}), 8.02(\mathrm{~d}, J=7.3 \mathrm{~Hz}, 1 \mathrm{H}), 7.54-7.46(\mathrm{~m}, 2 \mathrm{H}), 6.15$ (dd, $J=16.9,10.0 \mathrm{~Hz}, 1 \mathrm{H}), 6.03(\mathrm{~d}, J=16.8 \mathrm{~Hz}, 1 \mathrm{H}), 5.54(\mathrm{~d}, J=9.9 \mathrm{~Hz}, 1 \mathrm{H}), 3.62(\mathrm{~d}, J=6.7 \mathrm{~Hz}, 1 \mathrm{H})$, $3.51(\mathrm{~d}, J=11.8 \mathrm{~Hz}, 2 \mathrm{H}), 2.63(\mathrm{t}, J=10.7 \mathrm{~Hz}, 2 \mathrm{H}), 1.82(\mathrm{~d}, J=10.9 \mathrm{~Hz}, 2 \mathrm{H}), 1.43(\mathrm{dd}, J=19.8$, 
$9.5 \mathrm{~Hz}, 2 \mathrm{H}) .{ }^{13} \mathrm{C}$ NMR (100 MHz, DMSO-d 6 ) $\delta: 164.28,160.99,136.10,133.33,132.14,127.71$, 127.50, 125.63, 123.31, 115.63, 115.47, 107.11, 44.99, 44.78, 30.89. ESI-MS: $m / z 455.3(\mathrm{M}+\mathrm{H})$, $457.3(\mathrm{M}+\mathrm{H}), \mathrm{C}_{17} \mathrm{H}_{19} \mathrm{BrN}_{4} \mathrm{O}_{4} \mathrm{~S}(455.33)$.

(R)-3-(N-(1-acryloylpiperidin-3-yl)sulfamoyl)-5-bromo-1H-indole-2-carboxamide (I-4)

White crystal, yield: $35 \%$. mp: 109-111 ${ }^{\circ} \mathrm{C} .{ }^{1} \mathrm{H}$ NMR (400 MHz, DMSO-d 6 ) $\delta: 12.71$ (s, 1H), $8.38(\mathrm{~s}, 1 \mathrm{H}), 8.17(\mathrm{~s}, 2 \mathrm{H}), 7.99(\mathrm{~d}, J=7.4 \mathrm{~Hz}, 1 \mathrm{H}), 7.51-7.44(\mathrm{~m}, 2 \mathrm{H}), 6.22(\mathrm{dd}, J=16.6,10.4 \mathrm{~Hz}$, 1H), $5.98(\mathrm{dd}, J=45.5,16.8 \mathrm{~Hz}, 1 \mathrm{H}), 5.56(\mathrm{dd}, J=45.6,10.3 \mathrm{~Hz}, 1 \mathrm{H}), 3.72(\mathrm{~d}, J=13.1 \mathrm{~Hz}, 1 \mathrm{H})$, $3.53(\mathrm{~d}, J=11.6 \mathrm{~Hz}, 1 \mathrm{H}), 3.11-3.05(\mathrm{~m}, 1 \mathrm{H}), 3.03-2.93(\mathrm{~m}, 1 \mathrm{H}), 2.46-2.27(\mathrm{~m}, 1 \mathrm{H}), 1.61-1.58(\mathrm{~m}$, $2 \mathrm{H}), 1.25(\mathrm{td}, J=18.6,10.4 \mathrm{~Hz}, 2 \mathrm{H}) .{ }^{13} \mathrm{C}$ NMR (100 MHz, DMSO-d 6 ) $\delta: 164.83,161.20,134.83$, 133.24, 128.92, 128.37, 127.74, 126.69, 123.39, 115.45, 115.17, 51.69, 50.96, 49.91, 41.72, 30.80 . ESI-MS: $m / 2456.99(\mathrm{M}+\mathrm{H}), 489.02(\mathrm{M}+\mathrm{Na}), \mathrm{C}_{17} \mathrm{H}_{19} \mathrm{BrN}_{4} \mathrm{O}_{4} \mathrm{~S}(455.33)$.

(S)-3-(N-(1-acryloylpyrrolidin-3-yl)sulfamoyl)-5-bromo-1H-indole-2-carboxamide (I-5)

White crystal, yield: $45 \%$. mp: $217-218^{\circ} \mathrm{C} .{ }^{1} \mathrm{H}$ NMR (400 MHz, DMSO-d 6 ) $\delta: 12.80$ (s, 1H), $8.40(\mathrm{~s}, 1 \mathrm{H}), 8.21(\mathrm{~s}, 1 \mathrm{H}), 8.16(\mathrm{~s}, 1 \mathrm{H}), 8.09(\mathrm{dd}, J=11.6,6.4 \mathrm{~Hz}, 1 \mathrm{H}), 7.52-7.45(\mathrm{~m}, 2 \mathrm{H}), 6.53-$ $6.31(\mathrm{~m}, 1 \mathrm{H}), 6.10-6.04(\mathrm{~m}, 1 \mathrm{H}), 5.65-5.59(\mathrm{~m}, 1 \mathrm{H}), 3.85-3.74(\mathrm{~m}, 1 \mathrm{H}), 3.62-3.53(\mathrm{~m}, 1 \mathrm{H}), 3.48-$ $3.38(\mathrm{~m}, 1 \mathrm{H}), 3.32-3.25(\mathrm{~m}, 1 \mathrm{H}), 3.16-3.06(\mathrm{~m}, 1 \mathrm{H}), 1.99-1.61(\mathrm{~m}, 2 \mathrm{H}) .{ }^{13} \mathrm{C}$ NMR $(100 \mathrm{MHz}$, DMSO-d $\left.\mathrm{d}_{6}\right) \delta: 163.70,161.14,134.99,133.30,129.80,129.57,127.69,127.27,126.67,123.42$, 115.20, 112.14, 51.82, 51.28, 31.96. ESI-MS: $m / z 441.3(\mathrm{M}+\mathrm{H}), 463.3(\mathrm{M}+\mathrm{Na}), 465.1(\mathrm{M}+\mathrm{Na})$, $\mathrm{C}_{16} \mathrm{H}_{17} \mathrm{BrN}_{4} \mathrm{O}_{4} \mathrm{~S}(441.30)$.

(R)-5-bromo-3-((3-(vinylsulfonamido)pyrrolidin-1-yl)sulfonyl)-1H-indole-2-carboxamide (I6)

White crystal, yield: $43 \%$. mp: $217-218^{\circ} \mathrm{C} .{ }^{1} \mathrm{H}$ NMR (400 MHz, DMSO- $\left.d_{6}\right) \delta: 13.02$ (s, $1 \mathrm{H}$ ), $8.41(\mathrm{~s}, 1 \mathrm{H}), 8.29(\mathrm{~s}, 1 \mathrm{H}), 8.14(\mathrm{t}, J=4.1 \mathrm{~Hz}, 1 \mathrm{H}), 7.68(\mathrm{~d}, J=6.7 \mathrm{~Hz}, 1 \mathrm{H}), 7.58-7.51(\mathrm{~m}, 2 \mathrm{H}), 6.70$ $(\mathrm{dd}, J=16.5,9.9 \mathrm{~Hz}, 1 \mathrm{H}), 6.02(\mathrm{~d}, J=16.5 \mathrm{~Hz}, 1 \mathrm{H}), 5.98(\mathrm{~d}, J=9.9 \mathrm{~Hz}, 1 \mathrm{H}), 3.69-3.61(\mathrm{~m}, 1 \mathrm{H})$, 3.52-3.47 (m, 1H), 3.35-3.33 (m, 1H), 3.26-3.20 (m, 1H), 3.07-3.03 (m, 1H), 2.08-1.99 (m, 1H), $1.72(\operatorname{td}, J=14.0,7.1 \mathrm{~Hz}, 1 \mathrm{H}) .{ }^{13} \mathrm{C}$ NMR $\left(100 \mathrm{MHz}, \mathrm{DMSO}-\mathrm{d}_{6}\right) \delta: 161.10,137.57,136.03,133.29$, 127.81, 127.71, 126.26, 123.34, 115.59, 115.47, 107.20, 53.27, 52.07, 46.14, 31.55. ESI-MS: $\mathrm{m} / \mathrm{z}$ $478.94(\mathrm{M}+\mathrm{H}), 500.92(\mathrm{M}+\mathrm{Na}), \mathrm{C}_{15} \mathrm{H}_{17} \mathrm{BrN}_{4} \mathrm{O}_{5} \mathrm{~S}_{2}$ (477.35).

(R)-5-bromo-3-(N-(1-(vinylsulfonyl)pyrrolidin-3-yl)sulfamoyl)-1H-indole-2-carboxamide (I-7) 
White crystal, yield: $37 \%$. mp: $240-242^{\circ} \mathrm{C} .{ }^{1} \mathrm{H}$ NMR (400 MHz, DMSO-d $d_{6} \delta: 12.78$ (s, 1H), $8.35(\mathrm{~s}, 1 \mathrm{H}), 8.20(\mathrm{~s}, 1 \mathrm{H}), 8.13(\mathrm{~s}, 1 \mathrm{H}), 8.05(\mathrm{~d}, J=6.3 \mathrm{~Hz}, 1 \mathrm{H}), 7.54-7.45(\mathrm{~m}, 2 \mathrm{H}), 6.76(\mathrm{dd}, J=$ 16.5, 10.0 Hz, 1H), $6.06(\mathrm{~d}, J=10.0 \mathrm{~Hz}, 1 \mathrm{H}), 6.01(\mathrm{~d}, J=16.5 \mathrm{~Hz}, 1 \mathrm{H}), 3.73(\mathrm{dd}, J=12.3,6.2 \mathrm{~Hz}$, $1 \mathrm{H}), 3.22-3.16(\mathrm{~m}, 2 \mathrm{H}), 3.13-3.07(\mathrm{~m}, 1 \mathrm{H}), 2.90(\mathrm{dd}, J=10.6,5.5 \mathrm{~Hz}, 1 \mathrm{H}), 1.89(\mathrm{td}, J=13.1,6.4$ $\mathrm{Hz}, 1 \mathrm{H}), 1.68(\mathrm{td}, J=13.9,7.0 \mathrm{~Hz}, 1 \mathrm{H}) .{ }^{13} \mathrm{C}$ NMR $\left(100 \mathrm{MHz}, \mathrm{DMSO}-\mathrm{d}_{6}\right) \delta: 161.27,135.46,133.30$, $132.03,129.07,127.66,126.53,123.34,115.44,115.21,111.73,52.81,52.37,46.04,31.54$. ESIMS: $m / z 477.0(\mathrm{M}+\mathrm{H}), 479.0(\mathrm{M}+\mathrm{H}), 499.0(\mathrm{M}+\mathrm{Na}), 501.0(\mathrm{M}+\mathrm{Na}), \mathrm{C}_{15} \mathrm{H}_{17} \mathrm{BrN}_{4} \mathrm{O}_{5} \mathrm{~S}_{2}(477.35)$

5-bromo-3-((4-(vinylsulfonamido)piperidin-1-yl)sulfonyl)-1H-indole-2-carboxamide (I-8)

White crystal, yield: $33 \% . \mathrm{mp}: 269-270^{\circ} \mathrm{C} .{ }^{1} \mathrm{H}$ NMR (400 MHz, DMSO-d 6 ) $\delta: 12.97$ (s, 1H), $9.35(\mathrm{~d}, J=7.6 \mathrm{~Hz}, 1 \mathrm{H}), 8.28(\mathrm{~s}, 1 \mathrm{H}), 8.21(\mathrm{~s}, 1 \mathrm{H}), 8.04(\mathrm{~s}, 1 \mathrm{H}), 7.53-7.46(\mathrm{~m}, 2 \mathrm{H}), 6.68(\mathrm{dd}, J=$ $16.5,9.9 \mathrm{~Hz}, 1 \mathrm{H}), 5.96(\mathrm{~d}, J=16.5 \mathrm{~Hz}, 1 \mathrm{H}), 5.87(\mathrm{~d}, J=9.9 \mathrm{~Hz}, 1 \mathrm{H}), 3.64(\mathrm{~d}, J=12.1 \mathrm{~Hz}, 2 \mathrm{H})$, 3.44-3.40 (m, 1H), 3.08-3.02 (m, 1H), 2.62-2.55 (m, 1H), $1.81(\mathrm{~d}, J=12.7 \mathrm{~Hz}, 2 \mathrm{H}), 1.59-1.45(\mathrm{~m}$, 2H). ESI-MS: $m / z 493.0(\mathrm{M}+\mathrm{H}), 513.0(\mathrm{M}+\mathrm{Na}), \mathrm{C}_{16} \mathrm{H}_{19} \mathrm{BrN}_{4} \mathrm{O}_{5} \mathrm{~S}_{2}(491.38)$.

(R)-5-bromo-3-(N-(1-(vinylsulfonyl)piperidin-3-yl)sulfamoyl)-1H-indole-2-carboxamide (I-9)

White crystal, yield: $36 \%$. mp: 130-132 ${ }^{\circ} \mathrm{C} .{ }^{1} \mathrm{H}$ NMR (400 MHz, DMSO-d 6 ) $\delta: 12.74$ (s, 1H), $8.37(\mathrm{~s}, 1 \mathrm{H}), 8.21(\mathrm{~s}, 1 \mathrm{H}), 8.16(\mathrm{~s}, 1 \mathrm{H}), 8.01(\mathrm{~d}, J=7.6 \mathrm{~Hz}, 1 \mathrm{H}), 7.52-7.45(\mathrm{~m}, 2 \mathrm{H}), 6.72(\mathrm{dd}, J=$ $16.5,10.0 \mathrm{~Hz}, 1 \mathrm{H}), 6.06(\mathrm{~d}, J=10.0 \mathrm{~Hz}, 1 \mathrm{H}), 5.98(\mathrm{~d}, J=16.5 \mathrm{~Hz}, 1 \mathrm{H}), 3.30(\mathrm{~d}, J=4.0 \mathrm{~Hz}, 1 \mathrm{H})$, 3.25-3.20 (m, 2H), 2.62-2.56 (m, 1H), 2.48-2.45 (m, 1H), 1.65-1.61 (m, 1H), 1.51-1.47 (m, 1H), 1.35-1.29 (m, 1H), 1.22-1.13 (m, 1H). ${ }^{13} \mathrm{C}$ NMR (100 MHz, DMSO-d 6$) \delta: 161.12,134.61,133.81$, $133.22,129.19,127.71,126.70,123.37,115.46,115.21,112.91,50.76,49.23,45.32,30.08,23.31$. ESI-MS: $m / z 492.95(\mathrm{M}+\mathrm{H}), 514.93(\mathrm{M}+\mathrm{Na}), \mathrm{C}_{16} \mathrm{H}_{19} \mathrm{BrN}_{4} \mathrm{O}_{5} \mathrm{~S}_{2}(491.38) .{ }^{13} \mathrm{C} \mathrm{NMR}(100 \mathrm{MHz}$, DMSO-d $\left.\mathrm{d}_{6}\right) \delta: 161.27,135.46,133.30,132.03,129.07,127.66,126.53,123.34,115.44,115.21$, 111.73, 52.81, 52.37, 46.04, 31.54. ESI-MS: $m / z 477.0(\mathrm{M}+\mathrm{H}), 479.0(\mathrm{M}+\mathrm{H}), 499.0(\mathrm{M}+\mathrm{Na}), 501.0$ $(\mathrm{M}+\mathrm{Na}), \mathrm{C}_{15} \mathrm{H}_{17} \mathrm{BrN}_{4} \mathrm{O}_{5} \mathrm{~S}_{2}(477.35)$.

4.1.6 Stability assays

Approximately $1 \mathrm{mg}$ of I-7 was weighed and dissolved in DMSO to obtain a $50 \mathrm{mM}$ solution of the compound, and then diluted to a final concentration of $2.5 \mathrm{mM}$ in commercial phosphate buffer solutions at pH 2.0 and 7.4 (Beijing Leagene Biotechnology, China). After incubating the sample for 24 hours at room temperatures, the stability of the compound was tested by measuring 
the retention time and peak recovery by reverse-phase HPLC using an Inertsil ODS-3 column (GL Sciences, Tokyo, Japan), and a methanol/water mobile phase.

\subsubsection{Reference NNRTIs}

Efavirenz was obtained from the AIDS Research and Reference Reagent Program, Division of AIDS, NIAID, NIH. Etravirine and rilpivirine were supplied by Tibotec Pharmaceuticals, Inc. L737,126 was synthesized as previously described $[13,14]$. Compound $7 \mathrm{e}$ was obtained by using methods described above. NMR parameters for this compound were: ${ }^{1} \mathrm{H}$ NMR (400 MHz, DMSO$\left.d_{6}\right) \delta 12.92(\mathrm{~s}, 1 \mathrm{H}), 8.31(\mathrm{~d}, J=63.8 \mathrm{~Hz}, 2 \mathrm{H}), 8.12(\mathrm{~d}, J=1.8 \mathrm{~Hz}, 1 \mathrm{H}), 7.52(\mathrm{~d}, J=8.8 \mathrm{~Hz}, 1 \mathrm{H}), 7.47(\mathrm{dt}$, $J=8.7,1.4 \mathrm{~Hz}, 1 \mathrm{H}), 3.15-3.18(\mathrm{~m}, 4 \mathrm{H}), 1.76-1.54(\mathrm{~m}, 4 \mathrm{H}) ;{ }^{13} \mathrm{C}$ NMR $\left(100 \mathrm{MHz}\right.$, DMSO- $\left.d_{6}\right) \delta 161.06$, $135.59,133.25,127.86,127.72,123.46,115.58,115.39,107.62,47.95(2 \times C), 25.01(2 \times C)$.

\subsection{In vitro anti-HIV assays}

Evaluation of the antiviral activity of the compounds against HIV in MT-4 cells was performed using the MTT assay as previously described $[15,16]$. Stock solutions (10 $\mathrm{x}$ final concentration) of test compounds were added in $25 \mu$ volumes to two series of triplicate wells so as to allow simultaneous evaluation of their effects on mock- and HIV-infected cells at the beginning of each experiment. Serial 5-fold dilutions of test compounds were made directly in flat-bottomed 96-well microtiter trays using a Biomek 3000 robot (Beckman instruments, Fullerton, CA). Untreated HIV- and mock-infected cell samples were included as controls. HIV stock (50 $\mu \mathrm{l})$ at 100-300 $\mathrm{CCID}_{50}(50 \%$ cell culture infectious doses) or culture medium was added to either the infected or mock-infected wells of the microtiter tray. Mock-infected cells were used to evaluate the effects of test compound on uninfected cells in order to assess the cytotoxicity of the test compounds. Exponentially growing MT-4 cells were centrifuged for 5 minutes at $220 \mathrm{~g}$ and the supernatant was discarded. The MT-4 cells were resuspended at $6 \times 10^{5}$ cells $/ \mathrm{ml}$ and $50 \mu 1$ volumes were transferred to the microtiter tray wells. Five days after infection, the viability of mock-and HIV-infected cells was examined spectrophotometrically using the MTT assay. The MTT assay is based on the reduction of yellow colored 3-(4,5-dimethylthiazol-2-yl)-2,5-diphenyltetrazolium bromide (MTT) (Acros Organics) by mitochondrial dehydrogenase activity in metabolically active cells to a bluepurple formazan that can be measured spectrophotometrically. The absorbances were read in an eight-channel computer-controlled photometer (Infinite M1000, Tecan), at two wavelengths (540 
and $690 \mathrm{~nm}$ ). All data were calculated using the median absorbance value of three wells. The 50\% cytotoxic concentration $\left(\mathrm{CC}_{50}\right)$ was defined as the concentration of the test compound that reduced the absorbance (optical density at $540 \mathrm{~nm}$ ) of the mock-infected control sample by $50 \%$. The concentration achieving $50 \%$ protection against the cytopathic effect of the virus in infected cells was defined as the $50 \%$ effective concentration $\left(\mathrm{EC}_{50}\right)$.

\subsection{Nucleotide incorporation and RT DNA polymerase inhibition assays}

WT HIV-1 $1_{\text {Bн10 }}$ RT was expressed in E. coli and purified as previously described [17, 18]. Inhibition of the DNA polymerase activity was determined in single nucleotide incorporation assays carried out with template-primer D38/25PGA, essentially as previously described [19]. Synthetic oligonucleotides D38 (5'-GGGTCCTTTCTTACCTGCAAGAATGTATAGCCCTACCA-3') and 25PGA (5'-TGGTAGGGCTATACATTCTTGCAGG-3') were obtained from Sigma-Aldrich. The primer $25 \mathrm{PGA}$ was labeled at its 5 ' terminus with $1-2 \mu \mathrm{Ci}$ of $\left[\gamma^{3}{ }^{32} \mathrm{P}\right] \mathrm{ATP}(10 \mathrm{mCi} / \mathrm{ml} ; 3000 \mathrm{Ci} / \mathrm{mmol}$, Perkin Elmer) and 5 units of T4 polynucleotide kinase (New England Biolabs) in $70 \mathrm{mM}$ Tris- $\mathrm{HCl}$ pH 7.6 buffer, containing $10 \mathrm{mM} \mathrm{MgCl} 2$ and $5 \mathrm{mM}$ DTT. In some experiments, DTT was excluded from the reaction mixture. The labeled primer was then annealed to D38 in $150 \mathrm{mM}$ magnesium acetate and $150 \mathrm{mM} \mathrm{NaCl}$. The template/primer molar ratio was adjusted to $1: 1$ and the concentration was $3 \mu \mathrm{M}$. Before the assay, the template-primer was diluted to a final concentration of $300 \mathrm{nM}$ in $550 \mathrm{mM}$ Hepes $\mathrm{pH} 7.0$ buffer, containing $150 \mathrm{mM}$ magnesium acetate and $150 \mathrm{mM}$ $\mathrm{NaCl}$

Nucleotide incorporation reactions were carried out in $50 \mathrm{mM}$ Hepes buffer $\mathrm{pH}$ 7.0, containing $15 \mathrm{mM}$ magnesium acetate, $15 \mathrm{mM} \mathrm{NaCl}, 130 \mathrm{mM}$ potassium acetate, $1 \mathrm{mM}$ DTT and $5 \%$ polyethylene glycol 6000. The concentrations of WT HIV-1 $1_{\mathrm{BH} 10}$ RT and D38/25PGA in these assays were $12 \mathrm{nM}$ and $30 \mathrm{nM}$, respectively. RT, template-primer and varying concentrations of the inhibitors were incubated at $37^{\circ} \mathrm{C}$ for 5 or $60 \mathrm{~min}$, before initiating the reaction by adding dTTP (GE Healthcare) to a final concentration of $100 \mu \mathrm{M}$. As a control, efavirenz, L-737,126 and compound 7e were tested under the same conditions. Nucleotide incorporation reactions were incubated for 15 and $30 \mathrm{~s}$ and then terminated by adding an equal volume of stop solution (10 mM EDTA in 90\% formamide containing $1 \mathrm{mg} / \mathrm{mL}$ xylene cyanol FF and $1 \mathrm{mg} / \mathrm{mL}$ bromphenol blue). Results were visualized on denaturing $20 \%$ polyacrylamide- $8 \mathrm{M}$ urea gels and primer extensions were determined 
by phosphoroimaging with a BAS1500 scanner (Fuji), using the program Tina version 2.09 (Raytest Isotopenmessgerate $\mathrm{Gmbh}$, Staubenhardt, Germany). $\mathrm{IC}_{50}$ values $(\mu \mathrm{M})$ were obtained from doseresponse curves using the GraphPad Prism software, after calculating the amount of elongated primer in the absence of inhibitor (at 5\% DMSO) and in the presence of drug at concentrations in the range of 0.01 to $100 \mu \mathrm{M}$.

\subsection{Mass spectrometry}

Matrix-assisted laser desorption/ionization-time of flight (MALDI-TOF) mass spectrometry was used to determine the molecular weight of complexes of I-7 with mutant Y181C HIV-1 $1_{\mathrm{BH} 10}$ RT. The enzyme at a final concentration of $29.4 \mu \mathrm{M}$ was incubated with the inhibitor (at different concentrations) in $50 \mathrm{mM}$ Tris- $\mathrm{HCl} \mathrm{pH} 8.0$, containing $50 \mathrm{mM} \mathrm{NaCl}, 5 \mathrm{mM} \mathrm{MgCl}_{2}$ and $3.3 \%$ DMSO at $37^{\circ} \mathrm{C}$ during $60 \mathrm{~min}$. Then, inhibitor and salts were removed by centrifugal ultrafiltration $(10,000$ molecular weight cut-off membranes, Microcon-10, Amicon, Merck Millipore). The sample (15 $\mu \mathrm{l})$ was diluted 20-fold with ultrapure distilled water and centrifuged at $14,000 \times \mathrm{g}$ for $6 \mathrm{~min}$. The process was repeated several times until the absorbance of the filtrate was below 0.001 , in the range of $220-300 \mathrm{~nm}$. The desalted protein was dried, resuspended in $30 \mu \mathrm{l}$ of aqueous $2 \%$ trifluoroacetic acid (TFA) solution. Samples were diluted at 1:1 ratio (v/v) with matrix solution (50\% saturated sinapinic acid in $70 \%$ aqueous acetonitrile and $0.1 \%$ trifluoroacetic acid). A $1.0 \mu$ laliquot of this mixture was manually deposited onto a 386-well OptiTOFTM Plate (ABSciex, Foster City, CA) and allowed to dry at room temperature.

Molecular weights were determined by using an ABi 4800 MALDI TOF/TOF mass spectrometer (SCIEX, Foster City, CA) in positive ion linear mode (the ion acceleration voltage was $25 \mathrm{kV}$ for MS acquisition). The detection mass range was set between 3,000 and 90,000 m/z.

\section{Trypsin digestion}

Samples were diluted in $20 \mu \mathrm{L}$ of multichaotropic sample solution UTT buffer (7 M urea, $2 \mathrm{M}$ thiourea, $100 \mathrm{mM}$ triethyl ammonium bicarbonate (TEAB) (Sigma-Aldrich), reduced with $2 \mu \mathrm{L}$ of $50 \mathrm{mM}$ Tris(2-carboxyethyl)phosphine (TCEP), $\mathrm{pH} 8.0$, at $37^{\circ} \mathrm{C}$ for $60 \mathrm{~min}$, followed by addition of $2 \mu \mathrm{L}$ of $100 \mathrm{mM}$ cysteine-blocking reagent chloroacetamide (Sigma-Aldrich) for $20 \mathrm{~min}$ at room temperature. Sample was diluted to $140 \mu \mathrm{L}$ to reduce the urea concentration with $25 \mathrm{mM}$ TEAB. 
Finally, digestion was initiated by adding $0.2 \mu \mathrm{g}$ of Pierce MS-grade trypsin (Thermo-Fisher Scientific Inc.) to each sample in a ratio $1: 20(\mathrm{w} / \mathrm{w})$, and then incubated at $37^{\circ} \mathrm{C}$ overnight on a shaker. Sample digestion was evaporated to dryness in a vacuum concentrator and resuspended in $0.1 \%$ formic acid.

\section{LC-ESI MS/MS}

A $1 \mu \mathrm{g}$ aliquot of each digested sample was subjected to 1D-nano LC ESI-MS/MS analysis using a nano-liquid chromatography system (Eksigent Technologies nanoLC Ultra 1D plus, SCIEX, Foster City, CA) coupled to high speed Triple TOF 5600 mass spectrometer (SCIEX, Foster City, CA) with a Nanospray III source. Peptides were separated using a 40 min-gradient ranging from $2 \%$ to $90 \%$ mobile phase B (mobile phase A: $2 \%$ acetonitrile, $0.1 \%$ formic acid; mobile phase B: $100 \%$ acetonitrile, $0.1 \%$ formic acid). The eluent was further analyzed with a TripleTOF 5600 System (SCIEX, Foster City, CA) in a positive ion mode. Mass spectra were acquired over a range of 100$1800 \mathrm{~m} / \mathrm{z}$. The maximum ion injection time was set at $250 \mathrm{~ms}$ for the survey scan and $100 \mathrm{~ms}$ for MS/MS scans for the 35 most intense signals in the acquired mass spectra.

\section{Analysis of peptides}

MS/MS spectra were exported to mgf format and searched using Mascot Server 2.7.1 (Matrix Science) against a custom protein database, containing the amino acid sequence encoded within the pol gene of HIV-1 together with commonly occurring contaminants. Search parameters were set as follows: enzyme, trypsin; allowed missed cleavages, 2; carbamidomethyl (C) as fixed modification and acetyl (Protein N-term), pyrrolidone from E, pyrrolidone from Q and Oxidation (M) as variable modifications. Peptide mass tolerance was set to $\pm 25 \mathrm{ppm}$ for precursors and $0.05 \mathrm{Da}$ for fragment masses.

\subsection{Computational methods}

Molecular docking of compound I-7 was performed with the Tripos molecular modeling packages Sybyl-X 2.0 [20], and optimized for 2000-generations until the maximum derivative of energy became $0.005 \mathrm{kcal} /\left(\mathrm{mol}^{*} \mathrm{~A}\right)$, using the Tripos force field. Atomic point charges were calculated using the Gasteiger-Huckel parameters. Docking analysis was carried out with the 
surflex-docking module of Discovery Studio 3.5, and the crystal structures of HIV-1 RT/NNRTI complexes (PDB files 2RF2 and 3DRR, for WT and mutant Y181C RTs). Bound ligands and water molecules were removed from the models. Then, hydrogen atoms were added, side chain amides and side chains bumps fixed, and charges and atom types were assigned according to CHARMM. After generating the protomol, the optimized I-7 was docked into the NNRTI binding pocket, setting the relevant parameters as defaults. Top-scoring poses were determined with the Sybyl-X 2.0 software and shown by the software of PyMOL version 1.5 (www.pymol.org).

\section{Conflict of interest}

The authors declare no conflict of interest.

\section{Acknowledgments}

Financial support from the National Natural Science Foundation of China (NSFC No. 81273354), the Key Project of NSFC for International Cooperation (No. 81420108027), the Key Research and Development Project of Shandong Province (No. 2017CXGC1401), the Young Scholars Program of Shandong University (YSPSDU No. 2016WLJH32, to P. Z.) and the Major Project of Science and Technology of Shandong Province (No. 2015ZDJS04001) are gratefully acknowledged. Work in Madrid was supported by grants PID2019-104176RBI00/AEI/10.13039/501100011033) (Spanish Ministry of Science and Innovation) and 2019AEP001 (CSIC), as well as an institutional grant of Fundación Ramón Areces (awarded to the CBMSO). Protein and peptide identifications by MS-MALDI-TOF and LC-ESI MS/MS were carried out in the Proteomics Facility of the Spanish National Center for Biotechnology (CNB-CSIC) that belongs to ProteoRed, PRB3-ISCIII, supported by grant PT17/0019. The technical assistance of Kris Uyttersprot and Kristien Erven in antiviral assays and Sergio Ciordia and Carlos García in mass spectrometry are gratefully acknowledged. Authors also thank Dr. Francisco J. Corrales (CNBCSIC) for helpful suggestions.

\section{References}

1. Zhan P, Pannecouque C, De Clercq E, Liu X: Anti-HIV Drug Discovery and Development: Current Innovations and Future Trends. Journal of medicinal chemistry 2016, 59(7):2849- 
2878.

2. Gubernick SI, Felix N, Lee D, Xu JJ, Hamad B: The HIV therapy market. Nature reviews Drug discovery 2016, 15(7):451-452.

3. Menéndez-Arias L: Molecular basis of human immunodeficiency virus type 1 drug resistance: overview and recent developments. Antiviral research 2013, 98(1):93-120.

4. Lai MT, Munshi V, Lu M, Feng M, Hrin-Solt R, McKenna PM, Hazuda DJ, Miller MD: Mechanistic Study of Common Non-Nucleoside Reverse Transcriptase InhibitorResistant Mutations with K103N and Y181C Substitutions. Viruses 2016, 8(10).

5. de Bethune MP: Non-nucleoside reverse transcriptase inhibitors (NNRTIs), their discovery, development, and use in the treatment of HIV-1 infection: a review of the last 20 years (1989-2009). Antiviral research 2010, 85(1):75-90.

6. Rhee SY, Blanco JL, Jordan MR, Taylor J, Lemey P, Varghese V, Hamers RL, Bertagnolio S, Rinke de Wit TF, Aghokeng AF et al: Geographic and temporal trends in the molecular epidemiology and genetic mechanisms of transmitted HIV-1 drug resistance: an individual-patient- and sequence-level meta-analysis. PLOS medicine 2015, 12(4):e1001810.

7. Avila-Rios S, Sued O, Rhee SY, Shafer RW, Reyes-Teran G, Ravasi G: Surveillance of HIV Transmitted Drug Resistance in Latin America and the Caribbean: A Systematic Review and Meta-Analysis. PloS one 2016, 11(6):e0158560.

8. Chan AH, Lee WG, Spasov KA, Cisneros JA, Kudalkar SN, Petrova ZO, Buckingham AB, Anderson KS, Jorgensen WL: Covalent inhibitors for eradication of drug-resistant HIV-1 reverse transcriptase: From design to protein crystallography. Proceedings of the National Academy of Sciences of the United States of America 2017, 114(36):9725-9730.

9. Williams TM, Ciccarone TM, MacTough SC, Rooney CS, Balani SK, Condra JH, Emini EA, Goldman ME, Greenlee WJ, Kauffman LR et al: 5-Chloro-3-(phenylsulfonyl)indole-2carboxamide: a novel, non-nucleoside inhibitor of HIV-1 reverse transcriptase. Journal of medicinal chemistry 1993, 36(9):1291-1294.

10. Silvestri R, De Martino G, La Regina G, Artico M, Massa S, Vargiu L, Mura M, Loi AG, Marceddu T, La Colla P: Novel indolyl aryl sulfones active against HIV-1 carrying NNRTI resistance mutations: synthesis and SAR studies. Journal of medicinal chemistry 2003, 46(12):2482-2493.

11. Famiglini V, Silvestri R: Indolylarylsulfones, a fascinating story of highly potent human immunodeficiency virus type 1 non-nucleoside reverse transcriptase inhibitors. Antiviral chemistry \& chemotherapy 2018, 26:2040206617753443.

12. Zhao Z, Wolkenberg SE, Sanderson PE, Lu M, Munshi V, Moyer G, Feng M, Carella AV, Ecto LT, Gabryelski LJ et al: Novel indole-3-sulfonamides as potent HIV non-nucleoside reverse transcriptase inhibitors (NNRTIs). Bioorganic \& medicinal chemistry letters 2008, 18(2):554-559.

13. Zhao T, Meng Q, Kang D, Ji J, De Clercq E, Pannecouque C, Liu X, Zhan P. Discovery of novel indolylarylsulfones as potent HIV-1 NNRTls via structure-guided scaffold morphing. European Journal of medicinal chemistry 2019, 15(182):111619.

14. Li X, Gao P, Huang B, Zhou Z, Yu Z, Yuan Z, Liu H, Pannecouque C, Daelemans D, De Clercq $E$, Zhan $P$, Liu $X$. Discovery of novel piperidine-substituted indolylarylsulfones as potent HIV NNRTIs via structure-guided scaffold morphing and fragment rearrangement. 
European Journal of medicinal chemistry 2017, 27(126):190-201.

15. Pauwels R, Balzarini J, Baba M, Snoeck R, Schols D, Herdewijn P, Desmyter J, De Clercq E: Rapid and automated tetrazolium-based colorimetric assay for the detection of anti-HIV compounds. Journal of virological methods 1988, 20(4):309-321.

16. Pannecouque C, Daelemans D, De Clercq E: Tetrazolium-based colorimetric assay for the detection of HIV replication inhibitors: revisited 20 years later. Nature protocols 2008, 3(3):427-434.

17. Boretto J, Longhi S, Navarro JM, Selmi B, Sire J, Canard B: An integrated system to study multiply substituted human immunodeficiency virus type 1 reverse transcriptase. Analytical biochemistry 2001, 292(1):139-147.

18. Matamoros T, Deval J, Guerreiro C, Mulard L, Canard B, Menendez-Arias L: Suppression of multidrug-resistant HIV-1 reverse transcriptase primer unblocking activity by alphaphosphate-modified thymidine analogues. Journal of molecular biology 2005, 349(3):451-463.

19. Betancor G, Alvarez M, Marcelli B, Andres C, Martinez MA, Menendez-Arias L: Effects of HIV-1 reverse transcriptase connection subdomain mutations on polypurine tract removal and initiation of (+)-strand DNA synthesis. Nucleic acids research 2015, 43(4):2259-2270.

20. Sybyl-X Molecular Modeling Software Packages, Version 2.0. TRIPOS Associates, Inc; St. Louis, MO, USA: 2012 
Supplementary Information

\section{Novel indolylarylsulfone derivatives as covalent HIV-1 reverse transcriptase inhibitors specifically targeting the drug-resistant mutant Y181C}

Ping Gao a,\#, Shu Songa,\#, Estrella Frutos-Beltrán ${ }^{\mathrm{b}, \#}$, Wenxin Lia ${ }^{\mathrm{a}}$, Bin Sun ${ }^{\mathrm{c}}$, Dongwei Kang ${ }^{a}$, Jinmi Zou a, Jian Zhang ${ }^{a}$, Christophe Pannecouqued, Erik De Clercq $^{d}$, Luis Menéndez-Arias ${ }^{\mathrm{b},{ }^{,},}$Peng Zhan ${ }^{\mathrm{a},{ }^{*}}$ and Xinyong Liu ${ }^{\mathrm{a},{ }^{*}}$

a Department of Medicinal Chemistry, Key Laboratory of Chemical Biology, Ministry of Education, School of Pharmaceutical Sciences, Shandong University, Ji'nan, 250012

${ }^{b}$ Centro de Biología Molecular "Severo Ochoa" (Consejo Superior de Investigaciones Cientificas \& Universidad Autónoma de Madrid), Madrid, Spain

c Institute of BioPharmaceutical Research, Liaocheng University, 1 Hunan Road, Liaocheng 252000, PR China

${ }^{d}$ Rega Institute for Medical Research, K. U. Leuven, Minderbroedersstraat 10, B-3000 Leuven, Belgium

* E-mail: Imenendez@cbm.csic.es (Menéndez-Arias L.); xinyongl@sdu.edu.cn (Liu X.Y.); zhanpeng1982@sdu.edu.cn (Zhan P.).

\# These authors contributed equally to this work. 
Table S1. LC-ESI MS/MS analysis of the tryptic hydrolysis of Y181C RT treated with I-7 (indicated as ias-8), and chloroacetamide.

\section{MATRIX MASCOT Search Results}

\section{Protein View: U00064}

Pol polyprotein mutant (Luis Menendez) OS=Human immunodeficiency virus

$\begin{array}{ll}\text { Database: } & \text { UsersDB_Home } \\ \text { Score: } & 18446 \\ \text { Monoisotopic mass (Mr): } & 65904 \\ \text { Calculated pI: } & 8.60\end{array}$

Sequence similarity is available as an NCBI BLAST search of U00064 against nr.

\section{Search parameters}

MS data file:

Enzyme:

Variable

modifications: $\backslash$ galatea.cnb.csic.es \servicio\LC-MALDI $\backslash$ Triple-TOF $\backslash$ Estrella Frutos CBMSO \20201029 3473\20201029 Varios_001_3473_3.mgf Trypsin/P: cuts C-term side of KR.

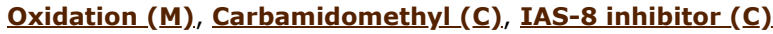

\section{Protein sequence coverage: $82 \%$}

Matched peptides shown in bold red.

1 MNSPISPIET VPVKLKPGMD GPKVKOWPLT EEKIKALVEI CTEMEKEGKI 51 SKIGPENPYN TPVFAIKKKD STKWRKLVDF RELNKRTQDF WEVQLGIPHP 101 AGLKKKKSVT VLDVGDAYFS VPLDEDFRKY TAFTIPSINN ETPGIRYQYN 151 VLPQGWKGSP AIFQSSMTKI LEPFKKQNPD IVICQYMDDL YVGSDLEIGQ 201 HRTKIEELRQ HLLRWGLTTP DKKHQKEPPF LWMGYELHPD KWTVQPIVLP 251 EKDSWTVNDI QKLVGKLNWA SQIYPGIKVR QLCKLLRGTK ALTEVIPLTE 301 EAELELAENR EILKEPVHGV YYDPSKDLIA EIQKQGQGQW TYQIYQEPFK 351 NLKTGKYARM RGAHTNDVKQ LTEAVQKITT ESIVIWGKTP KFKLPIQKET 401 WETWWTEYWQ ATWIPEWEFV NTPPLVKLWY QLEKEPIVGA ETFYVDGAAN 451 RETKLGKAGY VTNKGRQKVV PLTNTTNQKT ELQAIYLALQ DSGLEVNIVT 501 DSQYALGIIQ AQPDKSESEL VNQIIEQLIK KEKVYLAWVP AHKGIGGNEQ 551 VDKLVSAGIR KYYESTHHHH HH

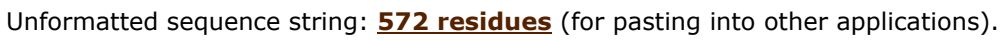
Sort by $\bigcirc$ residue number
increasing mass decreasing mass

Show $\bigcirc$ matched peptides only $\bigcirc$ predicted peptides also

Show $\bigcirc$ uncorrected delta $\bigcirc$ delta corrected for $13 \mathrm{C}$

\begin{tabular}{|c|c|}
\hline Query & Start - End \\
\hline$\triangle 1562$ & $1-14$ \\
\hline$\triangle 1563$ & $1-14$ \\
\hline$\widetilde{1566}$ & $1-14$ \\
\hline$\triangle 1567$ & $1-14$ \\
\hline$\overline{1568}$ & $1-14$ \\
\hline$\triangle 1569$ & $1-14$ \\
\hline$\triangle 1570$ & $1-14$ \\
\hline$\triangle 1571$ & $1-14$ \\
\hline $\mathbb{X}^{1572}$ & $1-14$ \\
\hline$\overline{1573}$ & $1-14$ \\
\hline$\triangle \underline{1575}$ & $1-14$ \\
\hline$\triangle 1576$ & $1-14$ \\
\hline$\triangle 1577$ & $1-14$ \\
\hline$\square \underline{1578}$ & $1-14$ \\
\hline$\triangle 1579$ & $1-14$ \\
\hline$\triangle 1580$ & $1-14$ \\
\hline$\triangle 1581$ & $1-14$ \\
\hline$\triangle 1582$ & $1-14$ \\
\hline$\square \underline{1584}$ & $1-14$ \\
\hline$\triangle 1586$ & $1-14$ \\
\hline$\checkmark 1587$ & $1-14$ \\
\hline$\square 1626$ & $1-14$ \\
\hline$\triangle 1628$ & $1-14$ \\
\hline$\triangle 3354$ & $1-23$ \\
\hline$\checkmark \overline{3355}$ & $1-23$ \\
\hline$\triangle 3357$ & $1-23$ \\
\hline$\checkmark \overline{3375}$ & $1-23$ \\
\hline
\end{tabular}

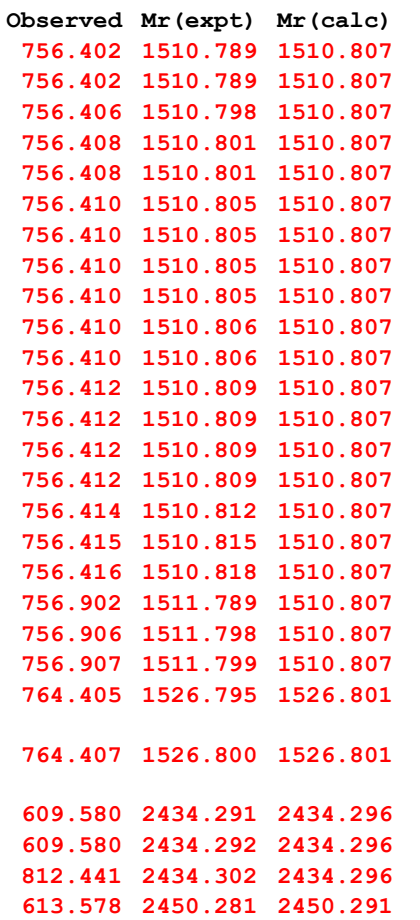

ppm M Score $-11.60$ $-11.40$ $-5.700$ $-3.950$ $-3.600$ $-1.100$ $-0.910$ $-0.720$ $-0.720$ $-0.470$ $-0.130$ 1.450

1.670

1.750

1.750

3.960

5.680

7.880

6500

6560 6570 $-4.040$

$-0.730$

$-2.072$

$-1.942$

$2.452 \quad 128$

$-4.16280$

\begin{tabular}{lr} 
Expect & Ran \\
$2.4 \mathrm{e}-06$ & 1 \\
$3.6 \mathrm{e}-05$ & 1 \\
$5.8 \mathrm{e}-06$ & 1 \\
$1.3 \mathrm{e}-06$ & 1 \\
0.00049 & 1 \\
0.00036 & 1 \\
$8.6 \mathrm{e}-07$ & 1 \\
$1.8 \mathrm{e}-09$ & 1 \\
$1.2 \mathrm{e}-07$ & 1 \\
$3.6 \mathrm{e}-05$ & 1 \\
$1.5 \mathrm{e}-06$ & 1 \\
$1.3 \mathrm{e}-05$ & 1 \\
$5.9 \mathrm{e}-07$ & 1 \\
$2.1 \mathrm{e}-08$ & 1 \\
$7.8 \mathrm{e}-10$ & 1 \\
0.00043 & 1 \\
$1.4 \mathrm{e}-05$ & 1 \\
0.00026 & 1 \\
$7.8 \mathrm{e}-06$ & 1 \\
0.00038 & 1 \\
$1.5 \mathrm{e}-05$ & 1 \\
$2.6 \mathrm{e}-09$ & 1 \\
$1.9 \mathrm{e}-08$ & 1 \\
$2.6 \mathrm{e}-09$ & 1 \\
$1.1 \mathrm{e}-12$ & 1 \\
$1.7 \mathrm{e}-13$ & 1 \\
$9.9 \mathrm{e}-09$ & 1 \\
& \\
\hline 1
\end{tabular}

U Peptide

U -.MNSPISPIETVPVK. L U -.MNSPISPIETVPVK. L U - MNSPISPIETVPVK. L U -.MNSPISPIETVPVK.L U - .MNSPISPIETVPVK. L U - MNSPISPIETVPVK. L U -.MNSPISPIETVPVK. L U -.MNSPISPIETVPVK. L U - MNSPISPIETVPVK. L U -.MNSPISPIETVPVK.L U -.MNSPISPIETVPVK. L -.MNSPISPIETVPVK. I U -.MNSPISPIETVPVK. L U - MNSPISPIETVPVK. L - MNSPISPIETVPVK. L U -.MNSPISPIETVPVK. L U - .MNSPISPIETVPVK. L J - MNSPISPIETVPVK.L U - MNSPISPIETVPVK. L $\mathrm{U}$-.MNSPISPIETVPVK. L

J -.MNSPISPIETVPVK.L

U -.MNSPISPIETVPVK.L + Oxidation (M)

U -.MNSPISPIETVPVK. I

+ Oxidation (M)

$\mathrm{U}-$-MNSPISPIETVPVKLKPGMDGPK.V

U -.MNSPISPIETVPVKLKPGMDGPK.V

U - .MNSPISPIETVPVKLKPGMDGPK.V

$\mathrm{U}-$. MNSPISPIETVPVKLKPGMDGPK.V

+ Oxidation (M) 


\begin{tabular}{|c|c|c|c|c|c|c|c|c|c|c|c|}
\hline Query & Start - End & Observed & $\operatorname{Mr}(\exp t)$ & $\operatorname{Mr}(\mathrm{calc})$ & ppm & M & Score & Expect & Rank & $\mathrm{U}$ & Peptide \\
\hline đ'3394 & $1-23$ & 617.577 & 2466.277 & 2466.286 & -3.76 & 2 & 125 & $3.4 e-13$ & 1 & $\bar{U}$ & $\begin{array}{l}\text {-. MNSPISPIETVPVKLKPGMDGPK.V } \\
+2 \text { Oxidation (M) }\end{array}$ \\
\hline$\square^{\prime 1166}$ & $2-14$ & 690.884 & 1379.754 & 1379.766 & -8.56 & 0 & 53 & $4.8 e-06$ & 1 & $\mathrm{U}$ & M.NSPISPIETVPVK.L \\
\hline 1167 & $2-14$ & 690.886 & 1379.757 & 1379.766 & -6.90 & 0 & 57 & $2.1 e-06$ & 1 & $\mathrm{U}$ & M.NSPISPIETVPVK. L \\
\hline$\overline{1169}$ & $2-14$ & 690.886 & 1379.758 & 1379.766 & -6.10 & 0 & 39 & 0.00013 & 1 & $\mathrm{U}$ & M.NSPISPIETVPVK. L \\
\hline$\overline{1170}$ & $2-14$ & 690.887 & 1379.760 & 1379.766 & -4.43 & 0 & 54 & $3.8 e-06$ & 1 & $\mathrm{U}$ & M.NSPISPIETVPVK.L \\
\hline$\checkmark 1171$ & $2-14$ & 690.887 & 1379.760 & 1379.766 & -4.43 & 0 & 66 & $2.3 e-07$ & 1 & $\mathrm{U}$ & M.NSPISPIETVPVK.L \\
\hline$\checkmark 1172$ & $2-14$ & 690.888 & 1379.762 & 1379.766 & -3.04 & 0 & 66 & $2.5 e-07$ & 1 & $\mathrm{U}$ & M.NSPISPIETVPVK. L \\
\hline$\overline{1173}$ & $2-14$ & 690.888 & 1379.762 & 1379.766 & -3.04 & 0 & 54 & $4 e-06$ & 1 & $\mathrm{U}$ & M.NSPISPIETVPVK. L \\
\hline$\underline{1175}$ & $2-14$ & 690.891 & 1379.767 & 1379.766 & 0.92 & 0 & 31 & 0.00088 & 1 & $\mathrm{U}$ & M.NSPISPIETVPVK. L \\
\hline$\overline{1180}$ & $2-14$ & 691.383 & 1380.751 & 1379.766 & 714 & 0 & 66 & $2.4 e-07$ & 1 & $\mathrm{U}$ & M.NSPISPIETVPVK. L \\
\hline$\overline{3203}$ & $2-23$ & 576.818 & 2303.244 & 2303.256 & -5.07 & 2 & 69 & $1.1 e-07$ & 1 & $\mathrm{U}$ & M.NSPISPIETVPVKLKPGMDGPK.V \\
\hline$\checkmark \underline{3204}$ & $2-23$ & 576.818 & 2303.244 & 2303.256 & -5.07 & 2 & 119 & $1.1 \mathrm{e}-12$ & 1 & $\mathrm{U}$ & M.NSPISPIETVPVKLKPGMDGPK.V \\
\hline$\overline{3205}$ & $2-23$ & 768.757 & 2303.250 & 2303.256 & -2.53 & 2 & 123 & $5.4 e-13$ & 1 & $\mathrm{U}$ & M.NSPISPIETVPVKLKPGMDGPK.V \\
\hline$\checkmark 3208$ & $2-23$ & 769.085 & 2304.234 & 2303.256 & 425 & 2 & 35 & 0.00035 & 1 & $\mathrm{U}$ & M.NSPISPIETVPVKLKPGMDGPK.V \\
\hline$\overline{3209}$ & $2-23$ & 577.069 & 2304.248 & 2303.256 & 431 & 2 & 78 & $1.5 e-08$ & 1 & U & M.NSPISPIETVPVKLKPGMDGPK.V \\
\hline$\widetilde{3233}$ & $2-23$ & 580.816 & 2319.234 & 2319.251 & -7.05 & 2 & 98 & $1.5 e-10$ & 1 & $\mathrm{U}$ & $\begin{array}{l}\text { M.NSPISPIETVPVKLKPGMDGPK.V } \\
+ \text { Oxidation (M) }\end{array}$ \\
\hline$\triangle \underline{263}$ & $15-23$ & 471.753 & 941.492 & 941.500 & -8.84 & 1 & 53 & $5.1 e-06$ & 1 & $\mathrm{U}$ & K. LKPGMDGPK.V \\
\hline$\varangle \underline{292}$ & $15-23$ & 479.751 & 957.487 & 957.495 & -8.37 & 1 & 46 & $2.3 e-05$ & 1 & $\mathrm{U}$ & $\begin{array}{l}\text { K. LKPGMDGPK.V } \\
+ \text { oxidation (M) }\end{array}$ \\
\hline$\triangle \underline{293}$ & $15-23$ & 479.751 & 957.488 & 957.495 & -8.10 & 1 & 37 & 0.00022 & 1 & $\mathrm{U}$ & $\begin{array}{l}\text { K. LKPGMDGPK.V } \\
\text { + Oxidatition (M) }\end{array}$ \\
\hline$\triangle \underline{294}$ & $15-23$ & 479.751 & 957.488 & 957.495 & -8.10 & 1 & 42 & $6.2 e-05$ & 1 & $\mathrm{U}$ & $\begin{array}{l}\text { K. LKPGMDGPK.V } \\
+ \text { Oxidation (M) }\end{array}$ \\
\hline$\varangle \underline{295}$ & $15-23$ & 479.751 & 957.488 & 957.495 & -8.10 & 1 & 46 & $2.4 e-05$ & 1 & $\mathrm{U}$ & $\begin{array}{l}\text { K. LKPGMDGPK.V } \\
\text { + Oxidation (M) }\end{array}$ \\
\hline$\triangle \underline{296}$ & $15-23$ & 479.751 & 957.488 & 957.495 & -7.77 & 1 & 49 & $1.3 e-05$ & 1 & $\mathrm{U}$ & $\begin{array}{l}\text { K. LKPGMDGPK.V } \\
\text { + Oxidatition (M) }\end{array}$ \\
\hline$\varangle \underline{297}$ & $15-23$ & 479.751 & 957.488 & 957.495 & -7.66 & 1 & 46 & $2.2 \mathrm{e}-05$ & 1 & $\mathrm{U}$ & $\begin{array}{l}\text { K. LKPGMDGPK.V } \\
+ \text { Oxidation (M) }\end{array}$ \\
\hline$\triangle \underline{298}$ & $15-23$ & 479.752 & 957.489 & 957.495 & -7.06 & 1 & 46 & $2.4 e-05$ & 1 & $\mathrm{U}$ & $\begin{array}{l}\text { K. LKPGMDGPK.V } \\
+ \text { Oxidatition (M) }\end{array}$ \\
\hline$\triangle \underline{299}$ & $15-23$ & 479.752 & 957.489 & 957.495 & -7.02 & 1 & 50 & $9 e-06$ & 1 & $\mathrm{U}$ & $\begin{array}{l}\text { K. LKPGMDGPK.V } \\
\text { + Oxidation (M) }\end{array}$ \\
\hline$\triangle \underline{300}$ & $15-23$ & 479.752 & 957.489 & 957.495 & -6.97 & 1 & 55 & $3.3 e-06$ & 1 & $\mathrm{U}$ & $\begin{array}{l}\text { K. LKPGMDGPK.V } \\
\text { + Oxidatition (M) }\end{array}$ \\
\hline$\checkmark \underline{301}$ & $15-23$ & 479.752 & 957.489 & 957.495 & -6.95 & 1 & 50 & $9.1 e-06$ & 1 & $\mathrm{U}$ & $\begin{array}{l}\text { K. LKPGMDGPK.V } \\
+ \text { Oxidation (M) }\end{array}$ \\
\hline$\varangle \underline{61}$ & $15-25$ & 390.557 & 1168.650 & 1168.664 & -11.9 & 2 & 35 & 0.00034 & 1 & $\mathrm{U}$ & K. LKPGMDGPKVK . Q \\
\hline$\checkmark \underline{693}$ & $15-25$ & 395.890 & 1184.647 & 1184.659 & -9.94 & 2 & 58 & $1.7 e-06$ & 1 & $\mathrm{U}$ & $\begin{array}{l}\text { K. LKPGMDGPKVK. Q } \\
\text { + Oxidation (M) }\end{array}$ \\
\hline$\triangle \underline{694}$ & $15-25$ & 395.890 & 1184.647 & 1184.659 & -9.94 & 2 & 54 & $4.3 e-06$ & 1 & $\mathrm{U}$ & $\begin{array}{l}\text { K. LKPGMDGPKVK. Q } \\
+ \text { Oxidation (M) }\end{array}$ \\
\hline$\triangle \underline{696}$ & $15-25$ & 395.890 & 1184.648 & 1184.659 & -9.16 & 2 & 58 & $1.4 \mathrm{e}-06$ & 1 & $\mathrm{U}$ & $\begin{array}{l}\text { K. LKPGMDGPKVK.Q } \\
+ \text { Oxidation (M) }\end{array}$ \\
\hline$\triangle \underline{697}$ & $15-25$ & 395.890 & 1184.648 & 1184.659 & -9.16 & 2 & 64 & $4.2 e-07$ & 1 & $\mathrm{U}$ & $\begin{array}{l}\text { K. LKPGMDGPKVK. Q } \\
+ \text { Oxidation (M) }\end{array}$ \\
\hline$\triangle 698$ & $15-25$ & 395.890 & 1184.648 & 1184.659 & -9.16 & 2 & 61 & $7.6 e-07$ & 1 & $\mathrm{U}$ & $\begin{array}{l}\text { K. LKPGMDGPKVK. Q } \\
\text { + Oxidation (M) }\end{array}$ \\
\hline$\triangle 10$ & $17-23$ & 359.161 & 716.307 & 716.316 & -12.8 & 0 & 50 & $9.1 \mathrm{e}-06$ & 1 & $\mathrm{U}$ & $\begin{array}{l}\text { K. PGMDGPK.V } \\
+ \text { Oxidation (M) }\end{array}$ \\
\hline$\triangle 11$ & $17-23$ & 359.161 & 716.307 & 716.316 & -12.7 & 0 & 32 & 0.00058 & 1 & $\mathrm{U}$ & $\begin{array}{l}\text { K. PGMDGPK.V } \\
+ \text { Oxidation (M) }\end{array}$ \\
\hline$\varangle \underline{14}$ & $17-23$ & 359.161 & 716.308 & 716.316 & -11.4 & 0 & 37 & 0.0002 & 1 & $\mathrm{U}$ & $\begin{array}{l}\text { K.PGMDGPK.V } \\
+ \text { Oxidation (M) }\end{array}$ \\
\hline$\triangle \underline{240}$ & $17-25$ & 464.747 & 927.480 & 927.485 & -5.43 & 1 & 48 & $1.5 e-05$ & 1 & $\mathrm{U}$ & K. PGMDGPKVK.Q \\
\hline 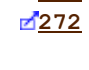 & $17-25$ & 472.745 & 943.476 & 943.480 & -4.36 & 1 & 45 & $3 e-05$ & 1 & $\mathrm{U}$ & $\begin{array}{l}\text { K. PGMDGPKVK.Q } \\
+ \text { oxidation (M) }\end{array}$ \\
\hline$\triangle \underline{273}$ & $17-25$ & 472.745 & 943.476 & 943.480 & -4.36 & 1 & 56 & $2.7 e-06$ & 1 & $\mathrm{U}$ & $\begin{array}{l}\text { K. PGMDGPKVK. } Q \\
+ \text { oxidation (M) }\end{array}$ \\
\hline$₫ \underline{275}$ & $17-25$ & 473.246 & 944.478 & 943.480 & 1058 & 1 & 33 & 0.00051 & 1 & $\mathrm{U}$ & $\begin{array}{l}\text { K. PGMDGPKVK. Q } \\
+ \text { Oxidation (M) }\end{array}$ \\
\hline$\checkmark \underline{899}$ & $24-33$ & 419.895 & 1256.664 & 1256.676 & -9.65 & 1 & 45 & $3.4 \mathrm{e}-05$ & 1 & $\mathrm{U}$ & K. VKQWPLTEEK. I \\
\hline$\overline{900}$ & $24-33$ & 419.896 & 1256.666 & 1256.676 & -8.12 & 1 & 50 & $1 e-05$ & 1 & $\mathrm{U}$ & K. VKQWPLTEEK. I \\
\hline$\overline{901}$ & $24-33$ & 419.896 & 1256.667 & 1256.676 & -7.76 & 1 & 47 & $2.2 e-05$ & 1 & $\mathrm{U}$ & K. VKQWPLTEEK. I \\
\hline$\overline{902}$ & $24-33$ & 419.896 & 1256.667 & 1256.676 & -7.31 & 1 & 47 & $2.1 e-05$ & 1 & $\mathrm{U}$ & K. VKQWPLTEEK . I \\
\hline 903 & $24-33$ & 629.344 & 1256.673 & 1256.676 & -2.74 & 1 & 48 & $1.7 e-05$ & 1 & $\mathrm{U}$ & K. VKQWPLTEEK. I \\
\hline$\overline{904}$ & $24-33$ & 629.344 & 1256.673 & 1256.676 & -2.74 & 1 & 74 & $4.2 e-08$ & 1 & $\mathrm{U}$ & K. VKQWPLTEEK. I \\
\hline$\checkmark \overline{1523}$ & $24-35$ & 375.467 & 1497.840 & 1497.855 & -10.1 & 2 & 49 & $1.3 e-05$ & 1 & $\mathrm{U}$ & K. VKQWPLTEEKIK.A \\
\hline$\checkmark 1525$ & $24-35$ & 500.289 & 1497.845 & 1497.855 & -6.76 & 2 & 57 & $2.2 e-06$ & 1 & $\mathrm{U}$ & K. VKQWPLTEEKIK. A \\
\hline$\overline{1526}$ & $24-35$ & 500.289 & 1497.845 & 1497.855 & -6.68 & 2 & 51 & $7.1 e-06$ & 1 & $\mathrm{U}$ & K. VKQWPLTEEKIK.A \\
\hline$\overline{1528}$ & $24-35$ & 500.290 & 1497.848 & 1497.855 & -5.22 & 2 & 73 & $5.2 e-08$ & 1 & $\mathrm{U}$ & K. VKQWPLTEEKIK. A \\
\hline$\varangle 947$ & $26-35$ & 424.567 & 1270.679 & 1270.692 & -9.94 & 1 & 49 & $1.3 e-05$ & 1 & $\mathrm{U}$ & K. QWPLTEEKIK.A \\
\hline$\varangle^{\prime 2} \overline{488}$ & $34-49$ & 470.245 & 1876.953 & 1876.964 & -5.86 & 2 & 50 & $1.1 \mathrm{e}-05$ & 1 & $\mathrm{U}$ & $\begin{array}{l}\text { K. IKALVEICTEMEKEGK. I } \\
+ \text { Carbamidomethyl } \\
\text { (C) }\end{array}$ \\
\hline$\checkmark 1072$ & $36-46$ & 661.816 & 1321.617 & 1321.626 & -6.96 & 0 & 64 & $3.6 e-07$ & 1 & $\mathrm{U}$ & $\begin{array}{l}\text { K.ALVEICTEMEK.E } \\
\begin{array}{ll}\text { + Carbamidomethyl } & \text { (C) }\end{array}\end{array}$ \\
\hline$\underbrace{\prime 1934}$ & $36-49$ & 546.264 & 1635.772 & 1635.785 & -8.07 & 1 & 89 & $1.2 \mathrm{e}-09$ & 1 & $\mathrm{U}$ & $\begin{array}{l}\text { K. ALVEICTEMEKEGK. I } \\
+ \text { Carbamidomethyl } \\
\text { (C) }\end{array}$ \\
\hline$\nabla^{\prime 1935}$ & $36-49$ & 546.265 & 1635.774 & 1635.785 & -6.46 & 1 & 71 & $8.7 e-08$ & 1 & $\mathrm{U}$ & $\begin{array}{l}\text { K.ALVEICTEMEKEGK. I } \\
+ \text { Carbamidomethyl } \\
\text { (C) }\end{array}$ \\
\hline
\end{tabular}




\begin{tabular}{|c|c|c|c|c|c|c|c|c|}
\hline Query & Start - End & Observed & $M r($ expt) & $\operatorname{Mr}(\mathrm{calc})$ & ppm & $\mathbf{M}$ & Score & Expect \\
\hline$\square^{\prime 1} 1936$ & $36-49$ & 546.265 & 1635.774 & 1635.785 & -6.46 & 1 & 107 & $1.9 e-11$ \\
\hline$\varangle 1937$ & $36-49$ & 546.267 & 1635.780 & 1635.785 & -2.68 & 1 & 84 & $4 e-09$ \\
\hline$\checkmark 1938$ & $36-49$ & 546.267 & 1635.780 & 1635.785 & -2.68 & 1 & 50 & $1 e-05$ \\
\hline$\varpi^{\prime 1941}$ & $36-49$ & 546.596 & 1636.765 & 1635.785 & 600 & 1 & 30 & 0.00093 \\
\hline$\square^{\prime} 1964$ & $36-49$ & 551.596 & 1651.767 & 1651.780 & -7.63 & 1 & 78 & $1.5 e-08$ \\
\hline$\varpi^{\prime} 1965$ & $36-49$ & 551.596 & 1651.767 & 1651.780 & -7.45 & 1 & 107 & $2.1 e-11$ \\
\hline$\varpi^{\prime} 1966$ & $36-49$ & 826.896 & 1651.778 & 1651.780 & -0.78 & 1 & 60 & $1 e-06$ \\
\hline$\varangle 2693$ & $36-52$ & 492.004 & 1963.988 & 1963.996 & -3.92 & 2 & 80 & $1.1 e-08$ \\
\hline$\nabla^{\prime 2694}$ & $36-52$ & 655.672 & 1963.994 & 1963.996 & -0.75 & 2 & 37 & 0.00018 \\
\hline$\varangle^{2695}$ & $36-52$ & 983.009 & 1964.003 & 1963.996 & 3.74 & 2 & 88 & $1.7 e-09$ \\
\hline$\varangle \underline{2696}$ & $36-52$ & 492.253 & 1964.983 & 1963.996 & 503 & 2 & 101 & $8.4 e-11$ \\
\hline$\triangle \underline{2720}$ & $36-52$ & 496.001 & 1979.974 & 1979.991 & -8.50 & 2 & 85 & $3.3 e-09$ \\
\hline$\triangle \underline{2721}$ & $36-52$ & 496.001 & 1979.974 & 1979.991 & -8.38 & 2 & 123 & $5.3 e-13$ \\
\hline$\varangle \underline{2723}$ & $36-52$ & 991.003 & 1979.992 & 1979.991 & 0.64 & 2 & 73 & $4.6 e-08$ \\
\hline$\varangle 2743$ & $50-67$ & 663.366 & 1987.075 & 1987.078 & -1.55 & 1 & 121 & $7.8 e-13$ \\
\hline$\varangle \underline{2744}$ & $50-67$ & 995.024 & 1988.033 & 1987.078 & 481 & 1 & 38 & 0.00014 \\
\hline$\varpi^{\prime 1977}$ & $53-67$ & 830.439 & 1658.863 & 1658.867 & -2.03 & 0 & 79 & $1.2 e-08$ \\
\hline$\varpi^{\prime} 1978$ & $53-67$ & 830.439 & 1658.863 & 1658.867 & -2.00 & 0 & 88 & $1.5 e-09$ \\
\hline$\triangle 1979$ & $53-67$ & 830.439 & 1658.864 & 1658.867 & -1.76 & 0 & 81 & $8.5 e-09$ \\
\hline$\varangle 1980$ & $53-67$ & 830.440 & 1658.865 & 1658.867 & -1.09 & 0 & 97 & $2.2 e-10$ \\
\hline$\varpi^{\prime} 1981$ & $53-67$ & 830.440 & 1658.866 & 1658.867 & -0.42 & 0 & 90 & $1 e-09$ \\
\hline ه'1982 & $53-67$ & 830.441 & 1658.867 & 1658.867 & 0.022 & 0 & 92 & $6.4 e-10$ \\
\hline$\varpi^{\prime 1983}$ & $53-67$ & 830.441 & 1658.867 & 1658.867 & 0.022 & 0 & 43 & $4.6 e-05$ \\
\hline$\varpi^{\prime} 1984$ & $53-67$ & 830.441 & 1658.867 & 1658.867 & 0.29 & 0 & 90 & $9.1 e-10$ \\
\hline$\varpi^{\prime} \underline{1985}$ & $53-67$ & 830.441 & 1658.867 & 1658.867 & 0.40 & 0 & 84 & $3.9 e-09$ \\
\hline$\checkmark 1986$ & $53-67$ & 830.441 & 1658.867 & 1658.867 & 0.42 & 0 & 78 & $1.5 e-08$ \\
\hline$\varpi^{\prime} 1987$ & $53-67$ & 830.441 & 1658.868 & 1658.867 & 0.76 & 0 & 93 & $5.1 e-10$ \\
\hline$\checkmark 1988$ & $53-67$ & 830.441 & 1658.868 & 1658.867 & 0.93 & 0 & 106 & $2.5 e-11$ \\
\hline$\varangle 1989$ & $53-67$ & 830.442 & 1658.869 & 1658.867 & 1.16 & 0 & 84 & $4.4 e-09$ \\
\hline$\varpi^{\prime 1990}$ & $53-67$ & 830.442 & 1658.869 & 1658.867 & 1.16 & 0 & 91 & 7. $3 e-10$ \\
\hline$\nabla^{\prime} 1991$ & $53-67$ & 830.442 & 1658.869 & 1658.867 & 1.32 & 0 & 75 & $2.9 e-08$ \\
\hline$\varpi^{\prime 1992}$ & $53-67$ & 830.442 & 1658.869 & 1658.867 & 1.37 & 0 & 82 & $6.7 e-09$ \\
\hline$\checkmark 1993$ & $53-67$ & 830.442 & 1658.869 & 1658.867 & 1.47 & 0 & 93 & $5 e-10$ \\
\hline$\varpi^{\prime} 1994$ & $53-67$ & 830.442 & 1658.869 & 1658.867 & 1.54 & 0 & 77 & $2.2 e-08$ \\
\hline$\nabla^{\prime 1995}$ & $53-67$ & 830.442 & 1658.870 & 1658.867 & 1.85 & 0 & 64 & $4.2 e-07$ \\
\hline$\nabla^{\prime} 1996$ & $53-67$ & 830.443 & 1658.871 & 1658.867 & 2.58 & 0 & 77 & $2.2 e-08$ \\
\hline$\nabla^{\prime 1} 1997$ & $53-67$ & 830.443 & 1658.872 & 1658.867 & 3.00 & 0 & 86 & $2.5 e-09$ \\
\hline$\varpi^{\prime 1998}$ & $53-67$ & 830.444 & 1658.873 & 1658.867 & 4.04 & 0 & 105 & $3.5 e-11$ \\
\hline$\varangle^{1999}$ & $53-67$ & 830.444 & 1658.874 & 1658.867 & 4.12 & 0 & 96 & $2.7 e-10$ \\
\hline$\triangle 2000$ & $53-67$ & 830.444 & 1658.874 & 1658.867 & 4.27 & 0 & 102 & $6.4 e-11$ \\
\hline$\varangle \underline{2001}$ & $53-67$ & 830.444 & 1658.874 & 1658.867 & 4.33 & 0 & 94 & $4.4 e-10$ \\
\hline$\checkmark \underline{2002}$ & $53-67$ & 830.444 & 1658.874 & 1658.867 & 4.33 & 0 & 97 & $2.2 e-10$ \\
\hline$\varangle ゙ 2003$ & $53-67$ & 830.444 & 1658.874 & 1658.867 & 4.42 & 0 & 91 & $8.9 e-10$ \\
\hline$\varangle \underline{2004}$ & $53-67$ & 830.447 & 1658.879 & 1658.867 & 7.30 & 0 & 105 & 3. $3 e-11$ \\
\hline$\varangle \underline{2005}$ & $53-67$ & 830.449 & 1658.883 & 1658.867 & 9.69 & 0 & 79 & $1.3 e-08$ \\
\hline$\varangle 2007$ & $53-67$ & 830.951 & 1659.887 & 1658.867 & 615 & 0 & 93 & $4.7 e-10$ \\
\hline$\varangle \underline{2008}$ & $53-67$ & 830.951 & 1659.888 & 1658.867 & 616 & 0 & 72 & $6.3 e-08$ \\
\hline$\varangle^{\prime 2317}$ & $53-68$ & 596.658 & 1786.954 & 1786.962 & -4.54 & 1 & 99 & $1.2 e-10$ \\
\hline$\varangle^{\prime 2} \underline{318}$ & $53-68$ & 596.659 & 1786.955 & 1786.962 & -3.76 & 1 & 98 & $1.6 e-10$ \\
\hline ه゙2319 & $53-68$ & 596.659 & 1786.955 & 1786.962 & -3.70 & 1 & 59 & $1.2 e-06$ \\
\hline$\varpi^{2} \underline{2585}$ & $53-69$ & 639.356 & 1915.047 & 1915.057 & -5.06 & 2 & 60 & $1.1 e-06$ \\
\hline$\nearrow^{\prime 59}$ & $76-81$ & 389.230 & 776.446 & 776.454 & -11.4 & 1 & 40 & 0.0001 \\
\hline$\nearrow^{\prime 916}$ & $76-85$ & 421.241 & 1260.702 & 1260.719 & -13.6 & 2 & 37 & 0.00021 \\
\hline$\triangle 0 \underline{987}$ & $77-86$ & 430.578 & 1288.713 & 1288.725 & -9.72 & 2 & 58 & $1.5 e-06$ \\
\hline$\checkmark \underline{989}$ & $77-86$ & 430.580 & 1288.718 & 1288.725 & -5.46 & 2 & 38 & 0.00016 \\
\hline$\triangle 0994$ & $77-86$ & 430.910 & 1289.707 & 1288.725 & 762 & 2 & 53 & $5.1 e-06$ \\
\hline$\underline{3235}$ & $86-105$ & 580.817 & 2319.238 & 2319.249 & -4.76 & 2 & 47 & $1.9 e-05$ \\
\hline$\nearrow^{\prime} \underline{1124}$ & $87-104$ & 679.350 & 2035.027 & 2035.053 & -12.7 & 0 & 31 & 0.00072 \\
\hline$\varangle 1125$ & $87-104$ & 679.352 & 2035.033 & 2035.053 & -9.45 & 0 & 52 & $5.9 e-06$ \\
\hline$\varangle^{2} 2835$ & $87-104$ & 679.358 & 2035.052 & 2035.053 & -0.40 & 0 & 71 & $7.4 e-08$ \\
\hline$\varangle \underline{1127}$ & $87-104$ & 679.359 & 2035.056 & 2035.053 & 1.65 & 0 & 78 & $1.6 e-08$ \\
\hline$\varangle 2836$ & $87-104$ & 1018.537 & 2035.059 & 2035.053 & 3.09 & 0 & 82 & $6.9 e-09$ \\
\hline$\checkmark \underline{3005}$ & $87-105$ & 541.792 & 2163.140 & 2163.148 & -3.39 & 1 & 34 & 0.0004 \\
\hline$\underline{3006}$ & $87-105$ & 541.792 & 2163.140 & 2163.148 & -3.39 & 1 & 51 & $7.8 e-06$ \\
\hline đ'3008 & $87-105$ & 722.057 & 2163.149 & 2163.148 & 0.59 & 1 & 65 & $3.4 e-07$ \\
\hline$\checkmark \underline{3009}$ & $87-105$ & 722.057 & 2163.149 & 2163.148 & 0.59 & 1 & 75 & $3.2 e-08$ \\
\hline$\checkmark 3011$ & 105 & 722.381 & 2164.122 & 2163.148 & 451 & 1 & 40 & $9.7 e-05$ \\
\hline
\end{tabular}

U Peptide

U K.ALVEIC TEMEKEGK. I + Carbamidomethyl (C)

U K. ALVEICTEMEKEGK. I

+ Carbamidomethyl (C)

U K.ALVEICTEMEKEGK. I

+ Carbamidomethyl (C)

U K.ALVEICTEMEKEGK. I

+ Carbamidomethyl (C)

U K. ALVEICTEMEKEGK. I

+ Carbamidomethyl (C); Oxidation (M)

U K.ALVEICTEMEKEGK.I

+ Carbamidomethyl (C); Oxidation (M)

U K.ALVEICTEMEKEGK. I

+ Carbamidomethyl (C); Oxidation (M)

U K.ALVEICTEMEKEGKISK. I

+ Carbamidomethyl (C)

U K.ALVEICTEMEKEGKISK. I

+ Carbamidomethyl (C)

U K. ALVEICTEMEKEGKISK. I

+ Carbamidomethyl (C)

U K.ALVEICTEMEKEGKISK. I

+ Carbamidomethyl (C)

U K.ALVEICTEMEKEGKISK. I

+ Carbamidomethyl (C); Oxidation (M)

U K. ALVEICTEMEKEGKISK. I

+ Carbamidomethyl (C); Oxidation (M)

U K.ALVEICTEMEKEGKISK. I

+ Carbamidomethyl (C); Oxidation (M)

$\mathrm{U} K$. ISKIGPENPYNTPVFAIK. $K$

U K.ISKIGPENPYNTPVFAIK.K

$U$ K. IGPENPYNTPVFAIK. K

$U$ U IGPENPYNTPVFAIK. $K$

U K. IGPENPYNTPVFAIK.K

U K. IGPENPYNTPVFAIK.K

U K. IGPENPYNTPVFAIK.K

U K. IGPENPYNTPVFAIK.K

U K. IGPENPYNTPVFAIK.K

U K. IGPENPYNTPVFAIK.K

U K. IGPENPYNTPVFAIK.K

U $K$. IGPENPYNTPVFAIK. $K$

U K. IGPENPYNTPVFAIK.K

U K. IGPENPYNTPVFAIK. K

U K. IGPENPYNTPVFAIK. K

U K. IGPENPYNTPVFAIK. K

U K. IGPENPYNTPVFAIK. K

U K. IGPENPYNTPVFAIK. K

U $\mathrm{K}$. IGPENPYNTPVFAIK . $\mathrm{K}$

U K. IGPENPYNTPVFAIK. K

U K. IGPENPYNTPVFAIK. K

U K. IGPENPYNTPVFAIK. K

U $\mathrm{K}$. IGPENPYNTPVFAIK. K

U K. IGPENPYNTPVFAIK. K

U $\mathrm{K}$. IGPENPYNTPVFAIK. $\mathrm{K}$

U K. IGPENPYNTPVFAIK.K

$\mathrm{U}$ K. IGPENPYNTPVFAIK. K

U K. IGPENPYNTPVFAIK. $K$

U K. IGPENPYNTPVFAIK.K

$U$ U IGPENPYNTPVFAIK. $K$

U K. IGPENPYNTPVFAIK. K

U K. IGPENPYNTPVFAIK. K

$U$ U. IGPENPYNTPVFAIK. $K$

U K. IGPENPYNTPVFAIKK. K

U K. IGPENPYNTPVFAIKK. K

$\mathrm{U}$ K. IGPENPYNTPVFAIKK $\mathrm{K}$

U K. IGPENPYNTPVFAIKKK. D

U R.KLVDFR.E

U R. KLVDFRELNK . R

U K. LVDFRELNKR.T

U K. LVDFRELNKR. T

U K IVDFRELNKR, T

U K. RTQDFWEVQLGIPHPAGLKK.K

U R. TQDFWEVQLGI PHPAGLK . K

U R. TODFWEVQLGIPHPAGLK. K

U R. TQDFWEVQLGIPHPAGLK.K

U R. TQDFWEVQLGIPHPAGLK . K

U R. TQDFWEVQLGI PHPAGLK. K

U R. TQDFWEVQLGI PHPAGLKK.K

U R. TODFWEVOLGI PHPAGLKK . K

U R. TQDFWEVQLGI PHPAGLKK.K

U R. TQDFWEVQLGIPHPAGLKK. K

U R. TQDFWEVOLGIPHPAGLKK . K 


\begin{tabular}{|c|c|c|c|c|c|c|c|c|c|c|c|}
\hline Query & Start - End & Observed & $M r(\exp t)$ & $\mathrm{Mr}(\mathrm{calc})$ & ppm & $\mathbf{M}$ & Score & Expect & Rank & $\mathrm{U}$ & Peptide \\
\hline$\checkmark ̛(3188$ & $87-106$ & 573.816 & 2291.235 & 2291.243 & -3.15 & 2 & 47 & $1.9 e-05$ & 1 & $\mathrm{U}$ & R. TQDFWEVQLGI PHPAGLKKK. K \\
\hline$\overline{3480}$ & $107-129$ & 650.834 & 2599.308 & 2599.317 & -3.29 & 2 & 102 & $6.7 e-11$ & 1 & $\mathrm{U}$ & K. KSVTVLDVGDAYFSVPLDEDFRK. Y \\
\hline$\checkmark 3274$ & $108-128$ & 1172.576 & 2343.136 & 2343.127 & 4.00 & 0 & 80 & $9.6 e-09$ & 1 & $\mathrm{U}$ & K. SVTVLDVGDAYFSVPLDEDFR. $\mathrm{K}$ \\
\hline$\checkmark \underline{3407}$ & $108-129$ & 824.750 & 2471.227 & 2471.222 & 2.01 & 1 & 179 & $1.2 \mathrm{e}-18$ & 1 & $\mathrm{U}$ & K.SVTVLDVGDAYFSVPLDEDFRK. Y \\
\hline$\overline{3408}$ & $108-129$ & 824.750 & 2471.227 & 2471.222 & 2.01 & 1 & 140 & $9.6 e-15$ & 1 & $\mathrm{U}$ & K.SVTVLDVGDAYFSVPLDEDFRK. Y \\
\hline$\underline{3409}$ & $108-129$ & 825.083 & 2472.227 & 2471.222 & 407 & 1 & 77 & $2.1 e-08$ & 1 & $\mathrm{U}$ & K.SVTVLDVGDAYFSVPLDEDFRK. Y \\
\hline$\checkmark \underline{3410}$ & $108-129$ & 825.091 & 2472.251 & 2471.222 & 417 & 1 & 45 & $3.2 e-05$ & 1 & $\mathrm{U}$ & K. SVTVLDVGDAYFSVPLDEDFRK. Y \\
\hline$₫ \underline{2803}$ & $129-146$ & 674.692 & 2021.054 & 2021.058 & -2.29 & 1 & 80 & $1.1 \mathrm{e}-08$ & 1 & $\mathrm{U}$ & R.KYTAFTIPSINNETPGIR.Y \\
\hline$\triangle \underline{1105}$ & $129-146$ & 674.698 & 2021.073 & 2021.058 & 7.52 & 1 & 31 & 0.00081 & 1 & $\mathrm{U}$ & R. KYTAFTIPSINNETPGIR.Y \\
\hline$\checkmark \underline{2515}$ & $130-146$ & 631.993 & 1892.957 & 1892.963 & -3.52 & 0 & 38 & 0.00015 & 1 & $\mathrm{U}$ & K. YTAFTIPSINNETPGIR.Y \\
\hline$\overline{2516}$ & $130-146$ & 947.487 & 1892.960 & 1892.963 & -1.90 & 0 & 49 & $1.3 e-05$ & 1 & $\mathrm{U}$ & K.YTAFTIPSINNETPGIR.Y \\
\hline$\underline{2517}$ & $130-146$ & 947.487 & 1892.960 & 1892.963 & -1.58 & 0 & 71 & $8.9 e-08$ & 1 & $\mathrm{U}$ & K.YTAFTIPSINNETPGIR.Y \\
\hline$\varangle \underline{2518}$ & $130-146$ & 947.487 & 1892.960 & 1892.963 & -1.57 & 0 & 62 & $6.6 e-07$ & 1 & $\mathrm{U}$ & K. YTAFTIPSINNETPGIR.Y \\
\hline$\checkmark 2519$ & $130-146$ & 947.488 & 1892.962 & 1892.963 & -0.85 & 0 & 89 & $1.4 \mathrm{e}-09$ & 1 & $\mathrm{U}$ & K. YTAFTIPSINNETPGIR.Y \\
\hline$\square \underline{2520}$ & $130-146$ & 947.490 & 1892.964 & 1892.963 & 0.67 & 0 & 76 & $2.4 \mathrm{e}-08$ & 1 & $\mathrm{U}$ & K.YTAFTIPSINNETPGIR.Y \\
\hline$₫ ِ \underline{2521}$ & $130-146$ & 947.490 & 1892.965 & 1892.963 & 1.19 & 0 & 64 & $3.9 e-07$ & 1 & U & K. YTAFTIPSINNETPGIR.Y \\
\hline$\checkmark 920$ & $130-146$ & 631.996 & 1892.966 & 1892.963 & 1.33 & 0 & 65 & $2.9 e-07$ & 1 & $\mathrm{U}$ & K. YTAFTIPSINNETPGIR.Y \\
\hline$\checkmark \underline{2522}$ & $130-146$ & 947.490 & 1892.966 & 1892.963 & 1.39 & 0 & 33 & 0.00055 & 1 & $\mathrm{U}$ & K.YTAFTIPSINNETPGIR.Y \\
\hline$\longdiv { 2 5 2 3 }$ & $130-146$ & 947.490 & 1892.966 & 1892.963 & 1.70 & 0 & 95 & $2.9 e-10$ & 1 & $\mathrm{U}$ & K.YTAFTIPSINNETPGIR.Y \\
\hline$\checkmark \underline{2524}$ & $130-146$ & 947.491 & 1892.967 & 1892.963 & 2.05 & 0 & 62 & $5.8 e-07$ & 1 & $\mathrm{U}$ & K. YTAFTIPSINNETPGIR.Y \\
\hline$\varangle \underline{2525}$ & $130-146$ & 947.491 & 1892.967 & 1892.963 & 2.11 & 0 & 96 & $2.4 \mathrm{e}-10$ & 1 & $\mathrm{U}$ & K.YTAFTIPSINNETPGIR.Y \\
\hline$\checkmark \underline{2526}$ & $130-146$ & 947.491 & 1892.968 & 1892.963 & 2.37 & 0 & 64 & $3.8 e-07$ & 1 & $\mathrm{U}$ & K.YTAFTIPSINNETPGIR.Y \\
\hline$\longdiv { 2 5 2 7 }$ & $130-146$ & 947.491 & 1892.968 & 1892.963 & 2.64 & 0 & 65 & $2.9 e-07$ & 1 & $\mathrm{U}$ & K.YTAFTIPSINNETPGIR.Y \\
\hline$\underline{2528}$ & $130-146$ & 947.492 & 1892.970 & 1892.963 & 3.37 & 0 & 55 & $3 e-06$ & 1 & $\mathrm{U}$ & K.YTAFTIPSINNETPGIR.Y \\
\hline$₫ \underline{2529}$ & $130-146$ & 947.493 & 1892.971 & 1892.963 & 3.89 & 0 & 94 & $4.5 e-10$ & 1 & U & K. YTAFTIPSINNETPGIR.Y \\
\hline$\checkmark \underline{2530}$ & $130-146$ & 947.493 & 1892.971 & 1892.963 & 4.31 & 0 & 97 & $2.1 e-10$ & 1 & $\mathrm{U}$ & K. YTAFTIPSINNETPGIR.Y \\
\hline$\overline{2531}$ & $130-146$ & 947.493 & 1892.971 & 1892.963 & 4.32 & 0 & 48 & $1.4 \mathrm{e}-05$ & 1 & $\mathrm{U}$ & K.YTAFTIPSINNETPGIR.Y \\
\hline$\checkmark \underline{2532}$ & $130-146$ & 947.494 & 1892.973 & 1892.963 & 5.08 & 0 & 54 & $4.1 e-06$ & 1 & $\mathrm{U}$ & K.YTAFTIPSINNETPGIR.Y \\
\hline$\longdiv { 2 5 3 3 }$ & $130-146$ & 947.494 & 1892.973 & 1892.963 & 5.25 & 0 & 52 & $6.4 e-06$ & 1 & $\mathrm{U}$ & K. YTAFTIPSINNETPGIR.Y \\
\hline 2534 & $130-146$ & 947.494 & 1892.974 & 1892.963 & 5.47 & 0 & 80 & $1.1 e-08$ & 1 & $\mathrm{U}$ & K.YTAFTIPSINNETPGIR.Y \\
\hline$\longdiv { 2 5 3 5 }$ & $130-146$ & 947.494 & 1892.974 & 1892.963 & 5.79 & 0 & 69 & $1.3 e-07$ & 1 & $\mathrm{U}$ & K.YTAFTIPSINNETPGIR.Y \\
\hline$₫ \underline{2536}$ & $130-146$ & 947.494 & 1892.974 & 1892.963 & 5.84 & 0 & 88 & $1.6 e-09$ & 1 & U & K. YTAFTIPSINNETPGIR.Y \\
\hline$₫ 2537$ & $130-146$ & 947.495 & 1892.975 & 1892.963 & 6.08 & 0 & 89 & $1.1 e-09$ & 1 & $\mathrm{U}$ & K. YTAFTIPSINNETPGIR.Y \\
\hline$\checkmark \underline{2538}$ & $130-146$ & 947.495 & 1892.975 & 1892.963 & 6.08 & 0 & 93 & $5.3 e-10$ & 1 & $\mathrm{U}$ & K.YTAFTIPSINNETPGIR.Y \\
\hline$\checkmark \underline{2539}$ & $130-146$ & 947.495 & 1892.975 & 1892.963 & 6.26 & 0 & 97 & $1.9 e-10$ & 1 & $\mathrm{U}$ & K.YTAFTIPSINNETPGIR.Y \\
\hline 2540 & $130-146$ & 947.496 & 1892.977 & 1892.963 & 7.06 & 0 & 45 & $3.3 e-05$ & 1 & $\mathrm{U}$ & K.YTAFTIPSINNETPGIR.Y \\
\hline$\overline{2541}$ & $130-146$ & 947.496 & 1892.978 & 1892.963 & 7.71 & 0 & 93 & $5.5 e-10$ & 1 & $\mathrm{U}$ & K. YTAFTIPSINNETPGIR.Y \\
\hline$\checkmark \underline{2542}$ & $130-146$ & 947.498 & 1892.981 & 1892.963 & 9.48 & 0 & 47 & $2 e-05$ & 1 & $\mathrm{U}$ & K.YTAFTIPSINNETPGIR.Y \\
\hline$\longdiv { 2 5 4 4 }$ & $130-146$ & 947.996 & 1893.977 & 1892.963 & 536 & 0 & 68 & $1.7 e-07$ & 1 & $\mathrm{U}$ & K.YTAFTIPSINNETPGIR.Y \\
\hline$\checkmark \underline{3710}$ & $130-157$ & 1090.896 & 3269.666 & 3269.651 & 4.62 & 1 & 83 & $4.5 e-09$ & 1 & $\mathrm{U}$ & K. YTAFTIPSINNETPGIRYQYNVLPQGWK.G \\
\hline$\varangle \underline{1234}$ & $147-157$ & 698.348 & 1394.681 & 1394.698 & -12.3 & 0 & 39 & 0.00012 & 1 & $\mathrm{U}$ & R. YQYNVLPQGWK.G \\
\hline$\checkmark 1235$ & $147-157$ & 698.354 & 1394.693 & 1394.698 & -4.09 & 0 & 38 & 0.00014 & 1 & $\mathrm{U}$ & R. YQYNVLPQGWK.G \\
\hline$\underline{1238}$ & $147-157$ & 698.355 & 1394.695 & 1394.698 & -2.23 & 0 & 30 & 0.001 & 1 & $\mathrm{U}$ & R. YQYNVLPQGWK.G \\
\hline$\checkmark \underline{1239}$ & $147-157$ & 698.355 & 1394.696 & 1394.698 & -1.35 & 0 & 36 & 0.00023 & 1 & $\mathrm{U}$ & R. YQYNVLPQGWK.G \\
\hline$\overline{1240}$ & $147-157$ & 698.356 & 1394.696 & 1394.698 & -1.31 & 0 & 32 & 0.00057 & 1 & $\mathrm{U}$ & R. YQYNVLPQGWK.G \\
\hline$\overline{1241}$ & $147-157$ & 698.356 & 1394.697 & 1394.698 & -0.82 & 0 & 44 & $4.4 e-05$ & 1 & $\mathrm{U}$ & R. YQYNVLPQGWK.G \\
\hline$\overline{1244}$ & $147-157$ & 698.357 & 1394.699 & 1394.698 & 0.53 & 0 & 43 & $5.5 e-05$ & 1 & $\mathrm{U}$ & R. YQYNVLPQGWK.G \\
\hline$\checkmark \underline{1245}$ & $147-157$ & 698.357 & 1394.699 & 1394.698 & 0.56 & 0 & 43 & $8.7 e-05$ & 1 & $\mathrm{U}$ & R. YQYNVLPQGWK.G \\
\hline$\square \underline{1246}$ & $147-157$ & 698.357 & 1394.699 & 1394.698 & 0.58 & 0 & 53 & $4.9 e-06$ & 1 & $\mathrm{U}$ & R. YQYNVLPQGWK.G \\
\hline$\checkmark 1247$ & $147-157$ & 698.357 & 1394.699 & 1394.698 & 0.58 & 0 & 55 & $3.4 e-06$ & 1 & $\mathrm{U}$ & R. YQYNVLPQGWK.G \\
\hline$\longdiv { 1 2 4 9 }$ & $147-157$ & 698.357 & 1394.700 & 1394.698 & 1.17 & 0 & 39 & 0.0002 & 1 & $\mathrm{U}$ & R. YQYNVLPQGWK.G \\
\hline$\checkmark 1251$ & $147-157$ & 698.359 & 1394.703 & 1394.698 & 3.28 & 0 & 38 & 0.00014 & 1 & $\mathrm{U}$ & R. YQYNVLPQGWK.G \\
\hline$\overline{1252}$ & $147-157$ & 698.359 & 1394.703 & 1394.698 & 3.34 & 0 & 35 & 0.0003 & 1 & $\mathrm{U}$ & R. YQYNVLPQGWK.G \\
\hline$\overline{1253}$ & $147-157$ & 698.359 & 1394.704 & 1394.698 & 4.20 & 0 & 35 & 0.00033 & 1 & $\mathrm{U}$ & R. YQYNVLPQGWK.G \\
\hline$\overline{1254}$ & $147-157$ & 698.360 & 1394.706 & 1394.698 & 5.36 & 0 & 35 & 0.00033 & 1 & $\mathrm{U}$ & R. YQYNVLPQGWK.G \\
\hline$\triangle \underline{1260}$ & $147-157$ & 698.855 & 1395.695 & 1394.698 & 715 & 0 & 30 & 0.0009 & 1 & $\mathrm{U}$ & R. YQYNVLPQGWK.G \\
\hline$\checkmark \underline{3495}$ & $147-169$ & 877.444 & 2629.312 & 2629.300 & 4.44 & 1 & 120 & $1.1 e-12$ & 1 & U & R. YQYNVLPQGWKGSPAIFQSSMTK . I \\
\hline$\checkmark 3496$ & $147-169$ & 877.444 & 2629.312 & 2629.300 & 4.44 & 1 & 147 & $2.1 e-15$ & 1 & $\mathrm{U}$ & R. YQYNVLPQGWKGSPAIFQSSMTK. I \\
\hline$\overline{3511}$ & $147-169$ & 882.775 & 2645.304 & 2645.295 & 3.54 & 1 & 111 & $8.2 e-12$ & 1 & $\mathrm{U}$ & $\begin{array}{l}\text { R. YQYNVLPQGWKGSPAIFQSSMTK. I } \\
+ \text { Oxidation (M) }\end{array}$ \\
\hline$\nearrow^{\prime 878}$ & $158-169$ & 627.311 & 1252.607 & 1252.612 & -4.05 & 0 & 63 & $4.5 e-07$ & 1 & $\mathrm{U}$ & K.GSPAIFQSSMTK. I \\
\hline$\longdiv { 8 8 0 }$ & $158-169$ & 627.311 & 1252.607 & 1252.612 & -4.05 & 0 & 88 & $1.6 e-09$ & 1 & $\mathrm{U}$ & K.GSPAIFQSSMTK. I \\
\hline$\longdiv { 8 8 3 }$ & $158-169$ & 627.312 & 1252.610 & 1252.612 & -1.72 & 0 & 35 & 0.00032 & 1 & $\mathrm{U}$ & K. GSPAIFQSSMTK. I \\
\hline$\triangle 884$ & $158-169$ & 627.313 & 1252.611 & 1252.612 & -0.70 & 0 & 39 & 0.00014 & 1 & $\mathrm{U}$ & K.GSPAIFQSSMTK. I \\
\hline 7885 & $158-169$ & 627.317 & 1252.619 & 1252.612 & 5.64 & 0 & 60 & $1.4 \mathrm{e}-06$ & 1 & $\mathrm{U}$ & K.GSPAIFQSSMTK. I \\
\hline$\triangle 890$ & $158-169$ & 627.828 & 1253.642 & 1252.612 & 822 & 0 & 52 & $5.8 e-06$ & 1 & $\mathrm{U}$ & K.GSPAIFQSSMTK. I \\
\hline$\triangle 932$ & $158-169$ & 635.309 & 1268.603 & 1268.607 & -3.28 & 0 & 83 & $5.3 e-09$ & 1 & $\mathrm{U}$ & $\begin{array}{l}\text { K.GSPAIFQSSMTK.I } \\
+ \text { oxidation (M) }\end{array}$ \\
\hline$\checkmark \underline{933}$ & $158-169$ & 635.309 & 1268.603 & 1268.607 & -3.28 & 0 & 87 & $2.1 e-09$ & 1 & $\mathrm{U}$ & $\begin{array}{l}\text { K.GSPAIFQSSMTK.I } \\
\text { + oxidation (M) }\end{array}$ \\
\hline$\checkmark \underline{934}$ & $158-169$ & 635.309 & 1268.603 & 1268.607 & -3.17 & 0 & 68 & $1.7 e-07$ & 1 & $\mathrm{U}$ & $\begin{array}{l}\text { K.GSPAIFQSSMTK.I } \\
+ \text { oxidation (M) }\end{array}$ \\
\hline$\checkmark \mathbf{9 3 5}$ & $158-169$ & 635.313 & 1268.611 & 1268.607 & 2.76 & 0 & 35 & 0.00031 & 1 & $\mathrm{U}$ & $\begin{array}{l}\text { K.GSPAIFQSSMTK. I } \\
\text { + oxidation (M) }\end{array}$ \\
\hline$\triangle \underline{936}$ & $158-169$ & 635.314 & 1268.613 & 1268.607 & 4.62 & 0 & 36 & 0.00025 & 1 & $\mathrm{U}$ & $\begin{array}{l}\text { K. GSPAIFQSSMTK. I } \\
\text { + Oxidation (M) }\end{array}$ \\
\hline$\triangle \underline{939}$ & $158-169$ & 424.214 & 1269.620 & 1268.607 & 798 & 0 & 53 & $5.4 e-06$ & 1 & $\mathrm{U}$ & $\begin{array}{l}\text { K. GSPAIFQSSMTK.I } \\
\text { + Oxidation (M) }\end{array}$ \\
\hline$\triangle \underline{32}$ & $170-175$ & 373.721 & 745.428 & 745.437 & -12.6 & 0 & 44 & $4 e-05$ & 1 & U & $\mathrm{K}$. ILEPFK. K \\
\hline$\checkmark \overline{33}$ & $170-175$ & 373.721 & 745.428 & 745.437 & -12.5 & 0 & 40 & 0.00011 & 1 & $\mathrm{U}$ & K. ILEPFK.K \\
\hline$\checkmark \underline{175}$ & $170-176$ & 437.770 & 873.525 & 873.532 & -7.89 & 1 & 46 & $2.4 \mathrm{e}-05$ & 1 & $\mathrm{U}$ & K. ILEPFKK. $Q$ \\
\hline
\end{tabular}




\begin{tabular}{|c|c|c|c|c|c|c|c|c|}
\hline Query & Start - End & Observed & $M r(\exp t)$ & $\mathrm{Mr}$ (calc) & ppm & M & Score & Expect \\
\hline 3751 & $170-202$ & 984.245 & 3932.951 & 3932.944 & 1.76 & 2 & 40 & 0.0001 \\
\hline$\checkmark \underline{3700}$ & $176-202$ & 802.388 & 3205.525 & 3205.517 & 2.29 & 1 & 51 & $8.2 e-06$ \\
\hline$\checkmark \underline{3670}$ & $177-202$ & 770.361 & 3077.414 & 3077.422 & -2.80 & 0 & 103 & $5 e-11$ \\
\hline$\checkmark \underline{3671}$ & $177-202$ & 1026.815 & 3077.424 & 3077.422 & 0.61 & 0 & 129 & $1.2 e-13$ \\
\hline$\checkmark 3733$ & $177-202$ & 1166.471 & 3496.391 & 3496.383 & 2.34 & 0 & 54 & $3.7 e-06$ \\
\hline$\triangle 187$ & $203-209$ & 444.757 & 887.499 & 887.508 & -9.52 & 1 & 31 & 0.00077 \\
\hline$\overline{188}$ & $203-209$ & 444.758 & 887.501 & 887.508 & -7.79 & 1 & 61 & $7.5 e-07$ \\
\hline$\checkmark \underline{1646}$ & $203-214$ & 384.727 & 1534.879 & 1534.894 & -9.94 & 2 & 75 & $3.3 e-08$ \\
\hline$\smile^{\prime} 1647$ & $203-214$ & 384.728 & 1534.883 & 1534.894 & -7.42 & 2 & 69 & $1.2 e-07$ \\
\hline$\varpi^{\prime} 1648$ & $203-214$ & 384.728 & 1534.883 & 1534.894 & -7.31 & 2 & 56 & $2.4 e-06$ \\
\hline$\square^{\prime 1649}$ & $203-214$ & 512.635 & 1534.884 & 1534.894 & -6.64 & 2 & 31 & 0.00084 \\
\hline$\checkmark 1650$ & $203-214$ & 384.728 & 1534.884 & 1534.894 & -6.56 & 2 & 104 & $4.4 e-11$ \\
\hline$\checkmark \overline{1651}$ & $203-214$ & 512.635 & 1534.884 & 1534.894 & -6.46 & 2 & 58 & $1.7 e-06$ \\
\hline$\triangle 1036$ & $205-214$ & 436.254 & 1305.739 & 1305.752 & -9.64 & 1 & 57 & $2 e-06$ \\
\hline$\overline{1037}$ & $205-214$ & 436.255 & 1305.742 & 1305.752 & -7.23 & 1 & 32 & 0.0007 \\
\hline$\checkmark \underline{1038}$ & $205-214$ & 436.255 & 1305.742 & 1305.752 & -7.23 & 1 & 35 & 0.0003 \\
\hline$\checkmark 1040$ & $205-214$ & 653.881 & 1305.748 & 1305.752 & -2.50 & 1 & 60 & $1.1 e-06$ \\
\hline$\nabla^{221}$ & $215-222$ & 459.236 & 916.458 & 916.465 & -8.22 & 0 & 30 & 0.00097 \\
\hline$\triangle \underline{422}$ & $215-223$ & 523.283 & 1044.551 & 1044.560 & -9.31 & 1 & 47 & $1.9 e-05$ \\
\hline $4 \underline{423}$ & $215-223$ & 523.284 & 1044.554 & 1044.560 & -6.15 & 1 & 41 & $8.6 e-05$ \\
\hline$\varangle 1 \overline{371}$ & $215-226$ & 719.905 & 1437.795 & 1437.773 & 15.5 & 2 & 56 & $2.7 e-06$ \\
\hline 3331 & $242-262$ & 832.776 & 2495.306 & 2495.306 & -0.11 & 1 & 84 & $4.1 \mathrm{e}-09$ \\
\hline$\overline{\triangle 710}$ & $263-278$ & 596.333 & 1785.977 & 1786.014 & -20.9 & 1 & 62 & $7 e-07$ \\
\hline$\overline{711}$ & $263-278$ & 596.336 & 1785.986 & 1786.014 & -15.8 & 1 & 58 & $1.6 e-06$ \\
\hline$\varangle \underline{2301}$ & $263-278$ & 596.337 & 1785.990 & 1786.014 & -13.6 & 1 & 72 & $5.6 e-08$ \\
\hline$\square^{\prime} \underline{2302}$ & $263-278$ & 596.337 & 1785.990 & 1786.014 & -13.5 & 1 & 36 & 0.00024 \\
\hline$\square^{\prime} \underline{2304}$ & $263-278$ & 596.339 & 1785.994 & 1786.014 & -11.3 & 1 & 66 & 2. $3 e-07$ \\
\hline$\checkmark 2305$ & $263-278$ & 596.339 & 1785.994 & 1786.014 & -11.1 & 1 & 65 & $3.1 e-07$ \\
\hline$\triangle 2306$ & $263-278$ & 596.339 & 1785.995 & 1786.014 & -10.5 & 1 & 51 & $8.1 e-06$ \\
\hline$\checkmark 2307$ & $263-278$ & 596.340 & 1785.998 & 1786.014 & -9.19 & 1 & 52 & $5.9 e-06$ \\
\hline$\longdiv { 2 3 0 8 }$ & $263-278$ & 596.340 & 1785.998 & 1786.014 & -9.09 & 1 & 44 & $3.9 e-05$ \\
\hline$\overline{2313}$ & $263-278$ & 596.345 & 1786.013 & 1786.014 & -0.38 & 1 & 98 & $1.6 e-10$ \\
\hline$\checkmark \underline{2322}$ & $263-278$ & 596.673 & 1786.996 & 1786.014 & 550 & 1 & 78 & $1.6 e-08$ \\
\hline$\checkmark 2323$ & $263-278$ & 596.681 & 1787.021 & 1786.014 & 564 & 1 & 52 & $5.9 e-06$ \\
\hline$\overline{2848}$ & $263-280$ & 511.300 & 2041.172 & 2041.184 & -5.83 & 2 & 83 & $5.2 e-09$ \\
\hline$\checkmark \underline{1195}$ & $267-278$ & 695.368 & 1388.722 & 1388.745 & -16.5 & 0 & 34 & 0.00051 \\
\hline$\checkmark \overline{1196}$ & $267-278$ & 695.372 & 1388.729 & 1388.745 & -11.6 & 0 & 58 & $1.6 e-06$ \\
\hline$\overline{1197}$ & $267-278$ & 695.372 & 1388.730 & 1388.745 & -11.2 & 0 & 51 & $7.6 e-06$ \\
\hline$\overline{1198}$ & $267-278$ & 695.373 & 1388.731 & 1388.745 & -10.3 & 0 & 31 & 0.00086 \\
\hline$\checkmark 1199$ & $267-278$ & 695.373 & 1388.732 & 1388.745 & -9.85 & 0 & 40 & 0.0001 \\
\hline$\checkmark \underline{1200}$ & $267-278$ & 695.374 & 1388.733 & 1388.745 & -8.70 & 0 & 40 & 0.00013 \\
\hline$\checkmark \underline{1201}$ & $267-278$ & 695.374 & 1388.733 & 1388.745 & -8.56 & 0 & 60 & $1.1 e-06$ \\
\hline$\overline{1203}$ & $267-278$ & 695.374 & 1388.734 & 1388.745 & -7.82 & 0 & 48 & $1.5 e-05$ \\
\hline$\overline{1204}$ & $267-278$ & 695.376 & 1388.737 & 1388.745 & -6.19 & 0 & 52 & $6.2 e-06$ \\
\hline$\checkmark \overline{1205}$ & $267-278$ & 695.376 & 1388.737 & 1388.745 & -5.65 & 0 & 47 & $1.9 e-05$ \\
\hline$\checkmark 1206$ & $267-278$ & 695.376 & 1388.738 & 1388.745 & -5.01 & 0 & 48 & $1.6 \mathrm{e}-05$ \\
\hline$\overline{1208}$ & $267-278$ & 695.378 & 1388.742 & 1388.745 & -2.32 & 0 & 52 & $6.6 e-06$ \\
\hline$\checkmark \underline{1210}$ & $267-278$ & 695.379 & 1388.743 & 1388.745 & -1.89 & 0 & 46 & $2.7 e-05$ \\
\hline$\nabla^{\prime} \underline{1211}$ & $267-278$ & 695.380 & 1388.745 & 1388.745 & -0.39 & 0 & 75 & 3. $3 e-08$ \\
\hline$\searrow^{\prime} 1212$ & $267-278$ & 695.380 & 1388.745 & 1388.745 & 0.14 & 0 & 51 & $8.8 e-06$ \\
\hline$\checkmark \underline{1213}$ & $267-278$ & 695.380 & 1388.746 & 1388.745 & 0.50 & 0 & 73 & $5 e-08$ \\
\hline$\checkmark \underline{1214}$ & $267-278$ & 695.382 & 1388.749 & 1388.745 & 2.87 & 0 & 36 & 0.00023 \\
\hline$\checkmark 1218$ & $267-278$ & 695.874 & 1389.733 & 1388.745 & 711 & 0 & 38 & 0.00015 \\
\hline$\checkmark 1219$ & $267-278$ & 695.874 & 1389.733 & 1388.745 & 711 & 0 & 31 & 0.00086 \\
\hline$\overline{1221}$ & $267-278$ & 695.876 & 1389.737 & 1388.745 & 714 & 0 & 61 & $7.2 e-07$ \\
\hline$\checkmark 1222$ & $267-278$ & 695.880 & 1389.745 & 1388.745 & 720 & 0 & 33 & 0.0005 \\
\hline$\checkmark \underline{1223}$ & $267-278$ & 695.881 & 1389.747 & 1388.745 & 721 & 0 & 60 & $9.3 e-07$ \\
\hline$\nearrow^{\prime} \underline{1954}$ & $267-280$ & 548.976 & 1643.905 & 1643.915 & -5.68 & 1 & 81 & $7.4 e-09$ \\
\hline$\overline{\triangle 774}$ & $281-290$ & 406.239 & 1215.697 & 1215.712 & -12.8 & 2 & 40 & $9.7 e-05$ \\
\hline$\checkmark \underline{3121}$ & $291-310$ & 747.393 & 2239.157 & 2239.158 & -0.62 & 0 & 119 & 1. $3 e-12$ \\
\hline 3545 & $291-314$ & 908.492 & 2722.455 & 2722.464 & -3.34 & 1 & 35 & 0.00029 \\
\hline$\varangle 2478$ & $311-326$ & 625.330 & 1872.967 & 1872.962 & 2.58 & 1 & 112 & $6 e-12$ \\
\hline$\overline{2479}$ & $311-326$ & 469.249 & 1872.968 & 1872.962 & 2.92 & 1 & 38 & 0.00016 \\
\hline$\checkmark 3572$ & $311-334$ & 557.699 & 2783.461 & 2783.475 & -5.02 & 2 & 54 & $3.7 e-06$ \\
\hline$\checkmark 3201$ & $315-334$ & 576.045 & 2300.153 & 2300.169 & -7.00 & 1 & 46 & 2. $3 e-05$ \\
\hline$\overline{1643}$ & $315-334$ & 767.731 & 2300.170 & 2300.169 & 0.71 & 1 & 81 & $8.4 e-09$ \\
\hline$\triangle 241$ & $327-334$ & 465.264 & 928.513 & 928.523 & -10.2 & 0 & 43 & $5.5 e-05$ \\
\hline$\triangle^{\prime 2769}$ & $335-350$ & 667.655 & 1999.944 & 1999.943 & 0.76 & 0 & 51 & $7.9 e-06$ \\
\hline$\varangle \underline{2770}$ & $335-350$ & 1000.987 & 1999.960 & 1999.943 & 8.73 & 0 & 98 & $1.6 e-10$ \\
\hline$\checkmark 3292$ & $335-353$ & 786.062 & 2355.163 & 2355.165 & -0.80 & 1 & 52 & $7 e-06$ \\
\hline$\overline{3293}$ & $335-353$ & 1178.599 & 2355.183 & 2355.165 & 7.90 & 1 & 95 & $3.2 e-10$ \\
\hline$\checkmark \overline{3505}$ & $335-356$ & 661.337 & 2641.320 & 2641.329 & -3.34 & 2 & 66 & $2.3 e-07$ \\
\hline$\checkmark \underline{2811}$ & $360-377$ & 507.263 & 2025.024 & 2025.043 & -9.35 & 2 & 75 & $3.2 e-08$ \\
\hline$\square^{\prime} \underline{2812}$ & $360-377$ & 507.263 & 2025.024 & 2025.043 & -8.91 & 2 & 42 & $6.7 e-05$ \\
\hline$\square$ & $360-377$ & 07.265 & 2025.030 & 2025.043 & -6.34 & 2 & 84 & $3.8 e-09$ \\
\hline
\end{tabular}

Peptide

FKKQNPDIVICQYMDDLYVGSDLEIGQHR . T + Carbamidomethyl (C)

U K. KQNPDIVICQYMDDLYVGSDLEIGQHR.T + Carbamidomethyl (C)

U K. QNPDIVICQYMDDLYVGSDLEIGQHR.T + Carbamidomethyl (C)

U K. QNPDIVICQYMDDLYVGSDLEIGQHR.T + Carbamidomethyl (C)

U K. QNPDIVICQYMDDLYVGSDLEIGQHR. T + IAS-8 inhibitor (C)

U R.TKIEELR.Q

U R. TKIEELR. $O$

U R. TKIEELRQHLLR.W

U R. TKIEELRQHLLR.W

U R. TKIEELROHLLR. W

U R. TKIEELRQHLLR.W

U R. TKIEELRQHLLR. W

U R. TKIEELROHLLR.W

U K. IEELRQHLLR. W

U K. IEELRQHLLR. W

U K. IEELROHLLR. W

U K. IEELRQHLLR. W

U R.WGLTTPDK. K

U R. WGLTTPDKK. H

U R.WGLTTPDKK.H

U R.WGLTTPDKKHQK.E

U K. WTVQPIVLPEKDSWTVNDIQK. I

U K. LVGKLNWASQIYPGIK.V

U K. LVGKLNWASQIYPGIK.V

U K. LVGKLNWASOIYPGIK.V

U K. LVGKLNWASQIYPGIK.V

U K. LVGKLNWASOIYPGIK. V

U K. LVGKLNWASOIYPGIK. V

U K. LVGKLNWASQIYPGIK.V

U K. LVGKLNWASOIYPGIK. V

U K. LVGKLNWASOIYPGIK. V

U K. LVGKLNWASQIYPGIK.V

U K. LVGKLNWASOIYPGIK. V

U K. LVGKLNWASQIYPGIK.V

U K. LVGKLNWASQIYPGIKVR. Q

U K. LNWASQIYPGIK. V

U K. LNWASQIYPGIK. V

U K. LNWASQIYPGIK.V

U K. LNWASOIYPGIK. V

U K. LNWASQIYPGIK. V

U K. LNWASQIYPGIK.V

U K. LNWASQIYPGIK. V

U K. LNWASQIYPGIK.V

U K. LNWASQIYPGIK.V

U $\mathrm{K}$. LNWASQIYPGIK. V

U K. LNWASQIYPGIK.V

U K. LNWASQIYPGIK.V

U K. LNWASOIYPGIK. V

U K. LNWASQIYPGIK.V

U K. LNWASQIYPGIK.V

U K. LNWASOIYPGIK.V

U K. LNWASQIYPGIK.V

U K. LNWASQIYPGIK.V

U $K$. LNWASOIYPGIK. V

U K. LNWASQIYPGIK.V

U K. LNWASQIYPGIK.V

U K. LNWASOIYPGIK. V

U K. LNWASQIYPGIKVR.Q

U R. QLCKLLRGTK. A

+ Carbamidomethyl (C)

U K. ALTEVIPLTEEAELELAENR. E

U K. ALTEVIPLTEEAELELAENREILK.E

U R.EILKEPVHGVYYDPSK. D

U R.EILKEPVHGVYYDPSK.D

U R.EILKEPVHGVYYDPSKDLIAEIQK.Q

U K. EPVHGVYYDPSKDLIAEIQK. $Q$

U K. EPVHGVYYDPSKDLIAEIQK.Q

U K. DLIAEIOK.Q

U K.QGQGQWTYQIYQEPFK.N

U K.QGQGQWTYQIYQEPFK.N

U K.QGQGQWTYQIYQEPFKNLK. T

U K.QGQGQWTYQIYQEPFKNLK. T

U K. QGQGQWTYQIYQEPFKNLKTGK.Y

U R.MRGAHTNDVKOLTEAVQK . I

U R.MRGAHTNDVKOLTEAVOK. I

U R.MRGAHTNDVKQLTEAVQK. I 


\begin{tabular}{|c|c|c|c|c|c|c|c|c|c|c|c|c|}
\hline Query & Start & - End & Observed & $\mathrm{Mr}$ (expt) & $\operatorname{Mr}(\mathrm{calc})$ & ppm & M & Score & Expect & Rank & $\mathrm{U}$ & Peptide \\
\hline$\mho^{\prime 2819}$ & 360 & -377 & 507.510 & 2026.012 & 2025.043 & 479 & 2 & 45 & $3.3 e-05$ & 1 & $\overline{\mathrm{U}}$ & R.MRGAHTNDVKQLTEAVQK. I \\
\hline$\checkmark \underline{2843}$ & 360 & -377 & 681.348 & 2041.024 & 2041.037 & -6.83 & 2 & 39 & 0.00012 & 1 & $\mathrm{U}$ & $\begin{array}{l}\text { R. MRGAHTNDVKQLTEAVQK. I } \\
+ \text { Oxidation (M) }\end{array}$ \\
\hline$\varangle \underline{2844}$ & 360 & -377 & 511.263 & 2041.024 & 2041.037 & -6.78 & 2 & 88 & $1.5 e-09$ & 1 & $\mathrm{U}$ & $\begin{array}{l}\text { R. MRGAHTNDVKQLTEAVQK. I } \\
+ \text { Oxidation (M) }\end{array}$ \\
\hline$\varangle \underline{2845}$ & 360 & -377 & 681.352 & 2041.034 & 2041.037 & -1.73 & 2 & 84 & $3.8 e-09$ & 1 & $\mathrm{U}$ & $\begin{array}{l}\text { R. MRGAHTNDVKQLTEAVQK. I } \\
+ \text { Oxidation (M) }\end{array}$ \\
\hline$\smile^{\prime} \underline{2191}$ & 362 & -377 & 580.301 & 1737.883 & 1737.901 & -10.5 & 1 & 42 & $6.5 e-05$ & 1 & $\mathrm{U}$ & R. GAHTNDVKQLTEAVQK. I \\
\hline$\mho^{\prime} \underline{2192}$ & 362 & -377 & 580.305 & 1737.894 & 1737.901 & -3.74 & 1 & 52 & $5.6 e-06$ & 1 & $\mathrm{U}$ & R. GAHTNDVKQLTEAVQK. I \\
\hline$\nearrow^{2} \underline{193}$ & 362 & -377 & 580.306 & 1737.895 & 1737.901 & -3.18 & 1 & 112 & $6.5 e-12$ & 1 & $\mathrm{U}$ & R. GAHTNDVKQLTEAVQK. I \\
\hline$\mho^{\prime 2196}$ & 362 & -377 & 435.726 & 1738.876 & 1737.901 & 561 & 1 & 32 & 0.00062 & 1 & $\mathrm{U}$ & R. GAHTNDVKQLTEAVQK. I \\
\hline$\varangle^{\prime 2198}$ & 362 & -377 & 870.452 & 1738.889 & 1737.901 & 569 & 1 & 37 & 0.0002 & 1 & $\mathrm{U}$ & R. GAHTNDVKQLTEAVQK. I \\
\hline$\varangle^{2} 18$ & 370 & -377 & 458.758 & 915.500 & 915.503 & -2.26 & 0 & 51 & $8.7 e-06$ & 1 & $\mathrm{U}$ & K. QLTEAVQK. I \\
\hline$\varangle \underline{2979}$ & 370 & -388 & 715.402 & 2143.185 & 2143.189 & -1.91 & 1 & 143 & $5.5 e-15$ & 1 & $\mathrm{U}$ & K. QLTEAVQKITTESIVIWGK. T \\
\hline$\sigma^{\prime 3402}$ & 370 & -391 & 618.350 & 2469.369 & 2469.384 & -6.21 & 2 & 47 & $1.8 e-05$ & 1 & $\mathrm{U}$ & K. QLTEAVQKITTESIVIWGKTPK.F \\
\hline$\checkmark 3403$ & 370 & -391 & 618.350 & 2469.370 & 2469.384 & -5.70 & 2 & 144 & $4.1 e-15$ & 1 & $\mathrm{U}$ & K. QLTEAVQKITTESIVIWGKTPK. F \\
\hline$\varangle^{8} \underline{856}$ & 378 & -388 & 623.850 & 1245.686 & 1245.697 & -8.88 & 0 & 45 & $3 e-05$ & 1 & $\mathrm{U}$ & K. ITTESIVIWGK.T \\
\hline$\nabla^{\prime 858}$ & 378 & -388 & 623.852 & 1245.690 & 1245.697 & -5.26 & 0 & 81 & $8.8 e-09$ & 1 & $\mathrm{U}$ & K. ITTESIVIWGK.T \\
\hline$\triangle^{\prime 859}$ & 378 & -388 & 623.854 & 1245.694 & 1245.697 & -2.36 & 0 & 45 & $3.2 e-05$ & 1 & $\mathrm{U}$ & K. ITTESIVIWGK.T \\
\hline$\varangle \underline{860}$ & 378 & -388 & 623.855 & 1245.695 & 1245.697 & -1.31 & 0 & 60 & $1 e-06$ & 1 & $\mathrm{U}$ & K. ITTESIVIWGK.T \\
\hline$\varangle \underline{861}$ & 378 & -388 & 623.855 & 1245.695 & 1245.697 & -1.27 & 0 & 82 & $7.1 e-09$ & 1 & $\mathrm{U}$ & K. ITTESIVIWGK.T \\
\hline$\varangle 862$ & 378 & -388 & 623.855 & 1245.695 & 1245.697 & -1.27 & 0 & 82 & $5.9 e-09$ & 1 & $\mathrm{U}$ & K. ITTESIVIWGK.T \\
\hline$\varangle \underline{863}$ & 378 & -388 & 623.855 & 1245.695 & 1245.697 & -1.18 & 0 & 80 & $9.3 e-09$ & 1 & $\mathrm{U}$ & K. ITTESIVIWGK.T \\
\hline$\square^{864}$ & 378 & -388 & 623.855 & 1245.696 & 1245.697 & -1.09 & 0 & 82 & $6.5 e-09$ & 1 & $\mathrm{U}$ & K. ITTESIVIWGK.T \\
\hline$\checkmark \mathbf{8 6 5}$ & 378 & -388 & 623.855 & 1245.696 & 1245.697 & -0.80 & 0 & 57 & $2 e-06$ & 1 & $\mathrm{U}$ & K. ITTESIVIWGK.T \\
\hline 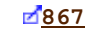 & 378 & -388 & 623.857 & 1245.700 & 1245.697 & 2.84 & 0 & 39 & 0.00012 & 1 & $\mathrm{U}$ & K. ITTESIVIWGK.T \\
\hline$\nabla^{\prime 871}$ & 378 & -388 & 624.354 & 1246.693 & 1245.697 & 800 & 0 & 55 & $3 e-06$ & 1 & $\mathrm{U}$ & K. ITTESIVIWGK. T \\
\hline$\mho^{\prime} 1776$ & 378 & -391 & 524.969 & 1571.884 & 1571.892 & -5.21 & 1 & 68 & $1.7 e-07$ & 1 & $\mathrm{U}$ & K. ITTESIVIWGKTPK.F \\
\hline$\mho^{\prime 1777}$ & 378 & -391 & 524.969 & 1571.884 & 1571.892 & -5.16 & 1 & 67 & $2 e-07$ & 1 & $\mathrm{U}$ & K. ITTESIVIWGKTPK.F \\
\hline$\mho^{\prime 1778}$ & 378 & -391 & 524.969 & 1571.885 & 1571.892 & -4.51 & 1 & 80 & $1 e-08$ & 1 & $\mathrm{U}$ & K. ITTESIVIWGKTPK.F \\
\hline$\square^{\prime 1780}$ & 378 & -391 & 786.954 & 1571.893 & 1571.892 & 0.66 & 1 & 98 & $1.7 e-10$ & 1 & $\mathrm{U}$ & K. ITTESIVIWGKTPK.F \\
\hline$\triangle \underline{172}$ & 392 & -398 & 437.278 & 872.541 & 872.548 & -8.58 & 1 & 38 & 0.00015 & 1 & $\mathrm{U}$ & K.FKLPIQK.E \\
\hline$\checkmark 3566$ & 428 & -451 & 923.804 & 2768.390 & 2768.381 & 3.15 & 1 & 107 & $1.9 e-11$ & 1 & $\mathrm{U}$ & K. LWYQLEKEPIVGAETFYVDGAANR . E \\
\hline$\checkmark \underline{3682}$ & 428 & -454 & 782.651 & 3126.574 & 3126.566 & 2.53 & 2 & 71 & $7.2 e-08$ & 1 & $\mathrm{U}$ & K. LWYQLEKEPIVGAETFYVDGAANRETK. L \\
\hline$\underbrace{\prime} 3683$ & 428 & -454 & 782.651 & 3126.575 & 3126.566 & 2.90 & 2 & 143 & $5.1 e-15$ & 1 & $\mathrm{U}$ & K. LWYQLEKEPIVGAETFYVDGAANRETK. L \\
\hline$\varangle \underline{3684}$ & 428 & -454 & 782.652 & 3126.577 & 3126.566 & 3.51 & 2 & 56 & $2.3 e-06$ & 1 & $\mathrm{U}$ & K. LWYQLEKEPIVGAETFYVDGAANRETK. I \\
\hline$\forall \underline{921}$ & 455 & -466 & 421.903 & 1262.686 & 1262.710 & -18.6 & 2 & 35 & 0.00033 & 1 & $\mathrm{U}$ & K. LGKAGYVTNKGR.Q \\
\hline$\mho^{\prime} 1447$ & 467 & -479 & 490.944 & 1469.811 & 1469.820 & -5.94 & 1 & 58 & $1.6 e-06$ & 1 & $\mathrm{U}$ & R.QKVVPLTNTTNQK.T \\
\hline$\llbracket \underline{767}$ & 469 & -479 & 607.838 & 1213.661 & 1213.667 & -4.70 & 0 & 78 & $1.5 e-08$ & 1 & $\mathrm{U}$ & K. VVPLTNTTNQK.T \\
\hline$\varangle \underline{872}$ & 516 & -531 & 624.356 & 1870.045 & 1870.041 & 2.16 & 1 & 38 & 0.00016 & 1 & $\mathrm{U}$ & K.SESELVNQIIEQLIKK.E \\
\hline$\nearrow^{\prime} 1380$ & 532 & -543 & 480.935 & 1439.784 & 1439.792 & -6.00 & 1 & 63 & $5 e-07$ & 1 & $\mathrm{U}$ & K. EKVYLAWVPAHK. G \\
\hline$\checkmark \underline{677}$ & 534 & -543 & 395.222 & 1182.646 & 1182.655 & -7.87 & 0 & 51 & $7.4 e-06$ & 1 & $\mathrm{U}$ & K. VYLAWVPAHK. G \\
\hline$\forall \underline{678}$ & 534 & -543 & 592.331 & 1182.647 & 1182.655 & -6.58 & 0 & 41 & $8.9 e-05$ & 1 & $\mathrm{U}$ & K. VYLAWVPAHK. G \\
\hline$\varangle \underline{680}$ & 534 & -543 & 592.331 & 1182.648 & 1182.655 & -5.55 & 0 & 31 & 0.00083 & 1 & $\mathrm{U}$ & K. VYLAWVPAHK.G \\
\hline$\triangle \underline{685}$ & 534 & -543 & 592.334 & 1182.654 & 1182.655 & -0.88 & 0 & 40 & 0.0001 & 1 & $\mathrm{U}$ & K. VYLAWVPAHK.G \\
\hline$\triangle \underline{687}$ & 534 & -543 & 592.335 & 1182.656 & 1182.655 & 0.47 & 0 & 33 & 0.00056 & 1 & $\mathrm{U}$ & K. VYLAWVPAHK.G \\
\hline 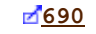 & 534 & -543 & 395.557 & 1183.649 & 1182.655 & 840 & 0 & 39 & 0.00013 & 1 & $\mathrm{U}$ & K. VYLAWVPAHK. G \\
\hline$\triangle \underline{691}$ & 534 & -543 & 592.836 & 1183.657 & 1182.655 & 848 & 0 & 32 & 0.00065 & 1 & $\mathrm{U}$ & K. VYLAWVPAHK. G \\
\hline$\varpi^{\prime 3615}$ & 534 & -560 & 576.318 & 2876.552 & 2876.566 & -4.98 & 2 & 68 & $1.5 e-07$ & 1 & $\mathrm{U}$ & K. VYLAWVPAHKGIGGNEQVDKLVSAGIR. K \\
\hline$\nabla^{\prime 3616}$ & 534 & -560 & 576.319 & 2876.557 & 2876.566 & -3.08 & 2 & 61 & $7.9 e-07$ & 1 & $\mathrm{U}$ & K. VYLAWVPAHKGIGGNEQVDKLVSAGIR. K \\
\hline$\overline{3617}$ & 534 & -560 & 720.147 & 2876.559 & 2876.566 & -2.35 & 2 & 201 & $7.8 e-21$ & 1 & $\mathrm{U}$ & K. VYLAWVPAHKGIGGNEQVDKLVSAGIR . K \\
\hline$\square \underline{1375}$ & 534 & -560 & 720.400 & 2877.570 & 2876.566 & 349 & 2 & 55 & $3.1 e-06$ & 1 & $\mathrm{U}$ & K. VYLAWVPAHKGIGGNEQVDKLVSAGIR. K \\
\hline$\checkmark \underline{389}$ & 544 & -553 & 508.751 & 1015.488 & 1015.493 & -5.49 & 0 & 68 & $1.5 e-07$ & 1 & $\mathrm{U}$ & K. GIGGNEQVDK. L \\
\hline$\varangle^{\prime 2131}$ & 544 & -560 & 571.640 & 1711.898 & 1711.922 & -13.8 & 1 & 58 & $1.6 e-06$ & 1 & $\mathrm{U}$ & K. GIGGNEQVDKLVSAGIR. K \\
\hline$\triangleleft^{\prime 2132}$ & 544 & -560 & 571.645 & 1711.913 & 1711.922 & -5.10 & 1 & 93 & $5.2 e-10$ & 1 & $\mathrm{U}$ & K. GIGGNEQVDKLVSAGIR. K \\
\hline$\varangle^{\prime 2133}$ & 544 & -560 & 571.645 & 1711.914 & 1711.922 & -4.75 & 1 & 95 & $2.9 e-10$ & 1 & $\mathrm{U}$ & K. GIGGNEQVDKLVSAGIR. K \\
\hline$\mho^{\prime 2134}$ & 544 & -560 & 571.645 & 1711.914 & 1711.922 & -4.50 & 1 & 91 & $8.4 e-10$ & 1 & $\mathrm{U}$ & K. GIGGNEQVDKLVSAGIR.K \\
\hline$\mho^{\prime 2135}$ & 544 & -560 & 571.645 & 1711.914 & 1711.922 & -4.50 & 1 & 129 & 1. $3 e-13$ & 1 & $\mathrm{U}$ & K. GIGGNEQVDKLVSAGIR. K \\
\hline$\varangle^{\prime 2136}$ & 544 & -560 & 571.646 & 1711.915 & 1711.922 & -3.73 & 1 & 47 & $2.2 e-05$ & 1 & $\mathrm{U}$ & K. GIGGNEQVDKLVSAGIR. K \\
\hline$\varangle \underline{5}$ & 554 & -560 & 358.222 & 714.430 & 714.439 & -11.8 & 0 & 36 & 0.00024 & 1 & $\mathrm{U}$ & K. LVSAGIR. K \\
\hline
\end{tabular}

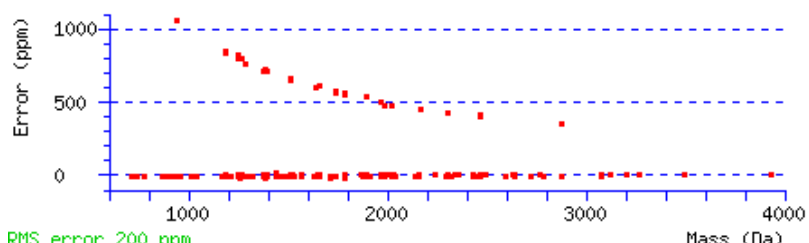

Mascot: http://www.matrixscience.com/ 
Table S2. LC-ESI MS/MS analysis of the tryptic hydrolysis of Y181C RT treated with chloroacetamide (control experiment without I-7).

\title{
I MATRIX MASCOT Search Results
}

\section{Protein View: U00064}

Pol polyprotein mutant (Luis Menendez) OS=Human immunodeficiency virus

$\begin{array}{ll}\text { Database: } & \text { UsersDB_Home } \\ \text { Score: } & 19737 \\ \text { Monoisotopic mass (Mr): } & 65904 \\ \text { Calculated pI: } & 8.60\end{array}$

Sequence similarity is available as an NCBI BLAST search of U00064 against nr.

\section{Search parameters}

MS data file:

Enzyme:

Variable

modifications:

\author{
$\backslash \backslash$ galatea.cnb.csic.es \servicio\LC-MALDI \Triple-TOF $\backslash$ Estrella \\ Frutos CBMSO $\backslash 20201029$ 3473\20201029 Varios 0033473 4.mgf \\ Trypsin/P: cuts C-term side of KR. \\ Oxidation (M)., Carbamidomethyl(ㄷ)., IAS-8 inhibitor(C).
}

Protein sequence coverage: $83 \%$

Matched peptides shown in bold red.

\begin{abstract}
1 MNSPISPIET VPVKLKPGMD GPKVKQWPLT EEKIKALVEI CTEMEKEGKI 51 SKIGPENPYN TPVFAIKKKD STKWRKLVDF RELNKRTQDF WEVQLGIPHP 101 AGLKKKKSVT VLDVGDAYFS VPLDEDFRKY TAFTIPSINN ETPGIRYQYN 151 VLPQGWKGSP AIFQSSMTKI LEPFKKONPD IVICQYMDDL YVGSDLEIGQ 201 HRTKIEELRQ HLLRWGLTTP DKKHQKEPPF LWMGYELHPD KWTVQPIVLP 251 EKDSWTVNDI QKLVGKLNWA SQIYPGIKVR QLCKLLRGTK ALTEVIPLTE 301 EAELELAENR EILKEPVHGV YYDPSKDLIA EIQKQGQGQW TYQIYQEPFK 351 NLKTGKYARM RGAHTNDVKQ LTEAVQKITT ESIVIWGKTP KFKLPIQKET 401 WETWWTEYWQ ATWIPEWEFV NTPPLVKLWY QLEKEPIVGA ETFYVDGAAN 451 RETKLGKAGY VTNKGRQKVV PLTNTTNQKT ELQAIYLALQ DSGLEVNIVT 501 DSQYALGIIQ AQPDKSESEL VNQIIEQLIK KEKVYLAWVP AHKGIGGNEQ 551 VDKLVSAGIR KYYESTHHHH HH
\end{abstract}

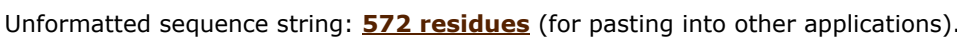

$\begin{array}{ll}\text { Sort by } \bigcirc \text { residue number } & \bigcirc \text { increasing mass } \\ \text { Show } \bigcirc \text { matched peptides only } \bigcirc \text { predicted peptides also } \\ \text { Show } \bigcirc \text { uncorrected delta } \bigcirc \text { delta corrected for } 13 \mathrm{C}\end{array}$

\begin{tabular}{|c|c|c|c|c|c|c|c|c|c|c|c|}
\hline Query & Start - End & Observed & $M r(\exp t)$ & $\operatorname{Mr}(\mathrm{calc})$ & ppm & M & Score & Expect & Rank & $\mathrm{U}$ & Peptide \\
\hline$\widetilde{\sim} 1432$ & $1-14$ & 504.602 & 1510.784 & 1510.807 & -14.8 & $\dddot{0}$ & 74 & $4.2 e-08$ & 1 & $\dddot{\mathrm{U}}$ & -.MNSPISPIETVPVK. L \\
\hline$\overline{1433}$ & $1-14$ & 756.406 & 1510.797 & 1510.807 & -5.97 & 0 & 29 & 0.0013 & 1 & $\mathrm{U}$ & -.MNSPISPIETVPVK.L \\
\hline 1434 & $1-14$ & 756.407 & 1510.800 & 1510.807 & -4.07 & 0 & 30 & 0.00095 & 1 & $\mathrm{U}$ & - .MNSPISPIETVPVK. I \\
\hline$\overline{1435}$ & $1-14$ & 756.408 & 1510.802 & 1510.807 & -3.29 & 0 & 43 & $4.6 e-05$ & 1 & $\mathrm{U}$ & -.MNSPISPIETVPVK.L \\
\hline$\triangle 1436$ & $1-14$ & 756.409 & 1510.803 & 1510.807 & -2.04 & 0 & 58 & $1.6 e-06$ & 1 & $\mathrm{U}$ & - .MNSPISPIETVPVK. L \\
\hline 1437 & $1-14$ & 756.409 & 1510.803 & 1510.807 & -2.00 & 0 & 32 & 0.00063 & 1 & $\mathrm{U}$ & -.MNSPISPIETVPVK. L \\
\hline 1438 & $1-14$ & 756.409 & 1510.803 & 1510.807 & -2.00 & 0 & 52 & $6.8 e-06$ & 1 & $\mathrm{U}$ & - MNSPISPIETVPVK. L \\
\hline 1439 & $1-14$ & 756.410 & 1510.805 & 1510.807 & -1.06 & 0 & 40 & $9.8 e-05$ & 1 & $\mathrm{U}$ & - MNSPISPIETVPVK. I \\
\hline$\overline{1440}$ & $1-14$ & 756.411 & 1510.807 & 1510.807 & 0.28 & 0 & 36 & 0.00024 & 1 & $\mathrm{U}$ & -.MNSPISPIETVPVK. L \\
\hline$\overline{1441}$ & $1-14$ & 756.412 & 1510.809 & 1510.807 & 1.62 & 0 & 47 & $2.2 e-05$ & 1 & $\mathrm{U}$ & -.MNSPISPIETVPVK. L \\
\hline$\overline{1442}$ & $1-14$ & 756.412 & 1510.809 & 1510.807 & 1.62 & 0 & 52 & $6.5 e-06$ & 1 & $\mathrm{U}$ & -.MNSPISPIETVPVK. L \\
\hline$\overline{1443}$ & $1-14$ & 756.412 & 1510.809 & 1510.807 & 1.66 & 0 & 31 & 0.00086 & 1 & $\mathrm{U}$ & -.MNSPISPIETVPVK.L \\
\hline$\checkmark 1444$ & $1-14$ & 756.412 & 1510.809 & 1510.807 & 1.78 & 0 & 29 & 0.0014 & 1 & $\mathrm{U}$ & - MNSPISPIETVPVK. I \\
\hline$\overline{1445}$ & $1-14$ & 756.412 & 1510.809 & 1510.807 & 1.86 & 0 & 30 & 0.00094 & 1 & $\mathrm{U}$ & -.MNSPISPIETVPVK.L \\
\hline 1446 & $1-14$ & 756.413 & 1510.811 & 1510.807 & 2.65 & 0 & 75 & $3.1 e-08$ & 1 & $\mathrm{U}$ & -.MNSPISPIETVPVK. L \\
\hline$\triangle 1447$ & $1-14$ & 756.413 & 1510.811 & 1510.807 & 2.69 & 0 & 83 & $5.5 e-09$ & 1 & $\mathrm{U}$ & -.MNSPISPIETVPVK. L \\
\hline$\overline{1449}$ & $1-14$ & 756.413 & 1510.811 & 1510.807 & 3.23 & 0 & 58 & $1.4 \mathrm{e}-06$ & 1 & $\mathrm{U}$ & - MNSPISPIETVPVK. I \\
\hline$\overline{1450}$ & $1-14$ & 756.413 & 1510.812 & 1510.807 & 3.66 & 0 & 43 & $4.6 e-05$ & 1 & $\mathrm{U}$ & -.MNSPISPIETVPVK. L \\
\hline 1451 & $1-14$ & 756.413 & 1510.812 & 1510.807 & 3.91 & 0 & 56 & $2.7 e-06$ & 1 & $\mathrm{U}$ & -.MNSPISPIETVPVK.L \\
\hline$\overline{1452}$ & $1-14$ & 756.414 & 1510.813 & 1510.807 & 4.50 & 0 & 49 & $1.3 e-05$ & 1 & $\mathrm{U}$ & -.MNSPISPIETVPVK. L \\
\hline$\overline{1453}$ & $1-14$ & 756.415 & 1510.815 & 1510.807 & 5.43 & 0 & 45 & $3.5 e-05$ & 1 & $\mathrm{U}$ & -.MNSPISPIETVPVK. L \\
\hline$\triangle 1457$ & $1-14$ & 756.911 & 1511.808 & 1510.807 & 663 & 0 & 44 & $3.8 e-05$ & 1 & $\mathrm{U}$ & -.MNSPISPIETVPVK. L \\
\hline$\overline{1504}$ & $1-14$ & 764.410 & 1526.806 & 1526.801 & 2.75 & 0 & 82 & $6.6 e-09$ & 1 & $\mathrm{U}$ & $\begin{array}{l}\text {-. MNSPISPIETVPVK. L } \\
+ \text { Oxidation (M) }\end{array}$ \\
\hline$\triangle 1505$ & $1-14$ & 764.410 & 1526.806 & 1526.801 & 2.81 & 0 & 79 & $1.2 e-08$ & 1 & $\mathrm{U}$ & $\begin{array}{l}\text { - MNSPISPIETVPVK.L } \\
+ \text { Oxidation (M) }\end{array}$ \\
\hline$\nearrow^{\prime 1506}$ & $1-14$ & 764.419 & 1526.823 & 1526.801 & 14.0 & 0 & 24 & 0.0039 & 1 & $\mathrm{U}$ & $\begin{array}{l}\text {-. MNSPISPIETVPVK. L } \\
+ \text { Oxidation (M) }\end{array}$ \\
\hline$\tau^{\prime 3438}$ & $1-23$ & 609.576 & 2434.274 & 2434.296 & -9.18 & 2 & 67 & $2.2 e-07$ & 1 & $\mathrm{U}$ & - .MNSPISPIETVPVKLKPGMDGPK.V \\
\hline$\checkmark 3440$ & $1-23$ & 609.579 & 2434.287 & 2434.296 & -4.02 & 2 & 126 & $2.4 e-13$ & 1 & $\mathrm{U}$ & -.MNSPISPIETVPVKLKPGMDGPK.V \\
\hline$\checkmark 1747$ & $1-23$ & 812.443 & 2434.306 & 2434.296 & 3.91 & 2 & 136 & $2.5 e-14$ & 1 & $\mathrm{U}$ & -.MNSPISPIETVPVKLKPGMDGPK.V \\
\hline 3468 & $1-23$ & 613.576 & 2450.273 & 2450.291 & -7.39 & 2 & 145 & $3.2 e-15$ & 1 & $\mathrm{U}$ & $\begin{array}{l}\text {-.MNSPISPIETVPVKLKPGMDGPK.V } \\
+ \text { Oxidation (M) }\end{array}$ \\
\hline$\widetilde{3493}$ & $1-23$ & 617.577 & 2466.279 & 2466.286 & -2.82 & 2 & 100 & $9.7 e-11$ & 1 & $\mathrm{U}$ & $\begin{array}{l}\text {-. MNSPISPIETVPVKLKPGMDGPK.V } \\
+2 \text { Oxidation (M) }\end{array}$ \\
\hline
\end{tabular}




\begin{tabular}{|c|c|c|c|c|c|c|c|c|c|c|c|}
\hline Query & Start - End & Observed & $M r(\exp t)$ & $\mathrm{Mr}(\mathrm{calc})$ & ppm & M & Score & Expect & Rank & $\mathrm{U}$ & Peptide \\
\hline 1081 & $2-14$ & 690.889 & 1379.764 & 1379.766 & -1.56 & $\dddot{0}$ & 56 & $2.4 e-06$ & 1 & $\dddot{U}$ & M.NSPISPIETVPVK. L \\
\hline$\overline{1082}$ & $2-14$ & 690.890 & 1379.765 & 1379.766 & -0.63 & 0 & 36 & 0.00024 & 1 & $\mathrm{U}$ & M.NSPISPIETVPVK. L \\
\hline$\overline{1083}$ & $2-14$ & 690.890 & 1379.766 & 1379.766 & -0.20 & 0 & 59 & $1.2 e-06$ & 1 & $\mathrm{U}$ & M.NSPISPIETVPVK.L \\
\hline$\overline{1084}$ & $2-14$ & 690.890 & 1379.766 & 1379.766 & -0.20 & 0 & 69 & $1.3 e-07$ & 1 & $\mathrm{U}$ & M.NSPISPIETVPVK. L \\
\hline$\overline{1088}$ & $2-14$ & 691.382 & 1380.749 & 1379.766 & 713 & 0 & 50 & $9.1 e-06$ & 1 & $\mathrm{U}$ & M.NSPISPIETVPVK.L \\
\hline$\overline{3273}$ & $2-23$ & 576.813 & 2303.221 & 2303.256 & -15.2 & 2 & 31 & 0.00072 & 1 & $\mathrm{U}$ & M.NSPISPIETVPVKLKPGMDGPK.V \\
\hline$\overline{3275}$ & $2-23$ & 576.817 & 2303.238 & 2303.256 & -7.69 & 2 & 120 & $1.1 e-12$ & 1 & $\mathrm{U}$ & M.NSPISPIETVPVKLKPGMDGPK.V \\
\hline 3279 & $2-23$ & 577.067 & 2304.240 & 2303.256 & 427 & 2 & 102 & $6.7 e-11$ & 1 & $\mathrm{U}$ & M.NSPISPIETVPVKLKPGMDGPK.V \\
\hline$\overline{3280}$ & $2-23$ & 769.089 & 2304.245 & 2303.256 & 429 & 2 & 35 & 0.0003 & 1 & $\mathrm{U}$ & M.NSPISPIETVPVKLKPGMDGPK.V \\
\hline$\longdiv { 3 2 9 9 }$ & $2-23$ & 580.814 & 2319.228 & 2319.251 & -9.90 & 2 & 86 & $2.5 e-09$ & 1 & $\mathrm{U}$ & $\begin{array}{l}\text { M.NSPISPIETVPVKLKPGMDGPK.V } \\
+ \text { Oxidation (M) }\end{array}$ \\
\hline$\varangle \underline{234}$ & $15-23$ & 471.749 & 941.484 & 941.500 & -17.4 & 1 & 53 & $4.7 e-06$ & 1 & $\mathrm{U}$ & K.LKPGMDGPK.V \\
\hline$\overline{262}$ & $15-23$ & 479.747 & 957.479 & 957.495 & -17.5 & 1 & 34 & 0.00036 & 1 & $\mathrm{U}$ & $\begin{array}{l}\text { K. LKPGMDGPK.V } \\
+ \text { Oxidation (M) }\end{array}$ \\
\hline$\triangle \underline{263}$ & $15-23$ & 479.747 & 957.479 & 957.495 & -17.5 & 1 & 44 & $4.2 e-05$ & 1 & $\mathrm{U}$ & $\begin{array}{l}\text { K. LKPGMDGPK.V } \\
+ \text { Oxidation (M) }\end{array}$ \\
\hline $\mathbb{Z}^{\prime 264}$ & $15-23$ & 479.747 & 957.479 & 957.495 & -17.5 & 1 & 50 & $9 e-06$ & 1 & $\mathrm{U}$ & $\begin{array}{l}\text { K.LKPGMDGPK.V } \\
\text { + Oxidation (M) }\end{array}$ \\
\hline$\varangle^{\prime 265}$ & $15-23$ & 479.747 & 957.479 & 957.495 & -17.2 & 1 & 44 & $3.9 e-05$ & 1 & $\mathrm{U}$ & $\begin{array}{l}\text { K.LKPGMDGPK.V } \\
+ \text { oxidätion (M) }\end{array}$ \\
\hline$\varangle^{\prime 266}$ & $15-23$ & 479.747 & 957.479 & 957.495 & -16.9 & 1 & 49 & $1.2 e-05$ & 1 & $\mathrm{U}$ & $\begin{array}{l}\text { K. LKPGMDGPK.V } \\
+ \text { Oxidation (M) }\end{array}$ \\
\hline$\varangle \underline{267}$ & $15-23$ & 479.747 & 957.479 & 957.495 & -16.6 & 1 & 48 & $1.8 e-05$ & 1 & $\mathrm{U}$ & $\begin{array}{l}\text { K. LKPGMDGPK.V } \\
+ \text { Oxidation (M) }\end{array}$ \\
\hline 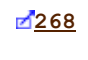 & $15-23$ & 479.747 & 957.480 & 957.495 & -16.5 & 1 & 46 & $2.4 e-05$ & 1 & $\mathrm{U}$ & $\begin{array}{l}\text { K.LKPGMDGPK.V } \\
\text { + Oxidation (M) }\end{array}$ \\
\hline$\forall \underline{269}$ & $15-23$ & 479.747 & 957.480 & 957.495 & -16.3 & 1 & 50 & $9 e-06$ & 1 & $\mathrm{U}$ & $\begin{array}{l}\text { K.LKPGMDGPK.V } \\
\text { + Oxidation (M) }\end{array}$ \\
\hline$\forall \underline{270}$ & $15-23$ & 479.747 & 957.480 & 957.495 & -16.3 & 1 & 52 & $5.8 e-06$ & 1 & $\mathrm{U}$ & $\begin{array}{l}\text { K.LKPGMDGPK.V } \\
+ \text { Oxidation (M) }\end{array}$ \\
\hline$\varangle^{\prime 271}$ & $15-23$ & 479.747 & 957.480 & 957.495 & -16.1 & 1 & 51 & $7.6 e-06$ & 1 & $\mathrm{U}$ & $\begin{array}{l}\text { K. LKPGMDGPK.V } \\
+ \text { Oxidation (M) }\end{array}$ \\
\hline$\nearrow^{\prime 649}$ & $15-25$ & 395.884 & 1184.631 & 1184.659 & -23.5 & 2 & 54 & $3.9 e-06$ & 1. & $\mathrm{U}$ & $\begin{array}{l}\text { K. LKPGMDGPKVK. } Q \\
+ \text { Oxidation (M) }\end{array}$ \\
\hline$\nearrow^{\prime 650}$ & $15-25$ & 395.884 & 1184.631 & 1184.659 & -23.5 & 2 & 52 & $5.7 e-06$ & 1 & $\mathrm{U}$ & $\begin{array}{l}\text { K. LKPGMDGPKVK. } Q \\
+ \text { Oxidation (M) }\end{array}$ \\
\hline$\varangle^{\prime 651}$ & $15-25$ & 395.884 & 1184.631 & 1184.659 & -23.5 & 2 & 66 & $2.5 e-07$ & 1 & $\mathrm{U}$ & $\begin{array}{l}\text { K.LKPGMDGPKVK. } Q \\
+ \text { Oxidation (M) }\end{array}$ \\
\hline$\varangle^{\prime 2} \underline{13}$ & $17-25$ & 464.742 & 927.469 & 927.485 & -17.3 & 1 & 70 & $1.1 e-07$ & 1 & $\mathrm{U}$ & K.PGMDGPKVK. $Q$ \\
\hline$\square 239$ & $17-25$ & 472.739 & 943.463 & 943.480 & -18.1 & 1 & 23 & 0.0051 & 1 & $\mathrm{U}$ & $\begin{array}{l}\text { K.PGMDGPKVK.Q } \\
+ \text { oxidation (M) }\end{array}$ \\
\hline$\nabla^{\prime 240}$ & $17-25$ & 472.740 & 943.465 & 943.480 & -16.0 & 1 & 55 & $3.1 e-06$ & 1 & $\mathrm{U}$ & $\begin{array}{l}\text { K. PGMDGPKVK.Q } \\
+ \text { Oxidation (M) }\end{array}$ \\
\hline$\square^{\prime 241}$ & $17-25$ & 472.740 & 943.465 & 943.480 & -16.0 & 1 & 49 & $1.3 e-05$ & 1 & $\mathrm{U}$ & $\begin{array}{l}\text { K.PGMDGPKVK.Q } \\
+ \text { Oxidation (M) }\end{array}$ \\
\hline$\varangle " 242$ & $17-25$ & 472.740 & 943.465 & 943.480 & -16.0 & 1 & 61 & $7.3 e-07$ & 1 & $\mathrm{U}$ & $\begin{array}{l}\text { K. PGMDGPKVK.Q } \\
+ \text { Oxidation (M) }\end{array}$ \\
\hline$\varangle \underline{244}$ & $17-25$ & 473.243 & 944.472 & 943.480 & 1051 & 1 & 21 & 0.0076 & 1 & $\mathrm{U}$ & $\begin{array}{l}\text { K. PGMDGPKVK.Q } \\
+ \text { Oxidation (M) }\end{array}$ \\
\hline$\square^{\prime 831}$ & $24-33$ & 419.891 & 1256.651 & 1256.676 & -20.0 & 1 & 41 & $7.6 e-05$ & 1 & $\mathrm{U}$ & K. VKQWPLTEEK . I \\
\hline$\overline{834}$ & $24-33$ & 629.343 & 1256.670 & 1256.676 & -4.77 & 1 & 74 & $4.1 e-08$ & 1 & $\mathrm{U}$ & K. VKQWPLTEEK . I \\
\hline$\square \overline{1392}$ & $24-35$ & 500.283 & 1497.828 & 1497.855 & -18.7 & 2 & 46 & $2.3 e-05$ & 1 & $\mathrm{U}$ & K.VKQWPLTEEKIK. A \\
\hline$\overline{1393}$ & $24-35$ & 500.283 & 1497.828 & 1497.855 & -18.1 & 2 & 22 & 0.0063 & 1 & $\mathrm{U}$ & K.VKQWPLTEEKIK. A \\
\hline 1394 & $24-35$ & 500.285 & 1497.833 & 1497.855 & -15.2 & 2 & 24 & 0.0043 & 1 & $\mathrm{U}$ & K. VKQWPLTEEKIK. A \\
\hline$\overline{1395}$ & $24-35$ & 500.285 & 1497.833 & 1497.855 & -15.2 & 2 & 53 & $4.9 e-06$ & 1 & $\mathrm{U}$ & K.VKQWPLTEEKIK.A \\
\hline$\triangle 1396$ & $24-35$ & 500.285 & 1497.833 & 1497.855 & -15.2 & 2 & 55 & $3.1 e-06$ & 1 & $\mathrm{U}$ & K. VKQWPLTEEKIK. A \\
\hline 1397 & $24-35$ & 500.285 & 1497.834 & 1497.855 & -14.5 & 2 & 30 & 0.00095 & 1 & $\mathrm{U}$ & K. VKQWPLTEEKIK. A \\
\hline$\overline{377}$ & $26-33$ & 515.757 & 1029.500 & 1029.513 & -12.3 & 0 & 28 & 0.0015 & 1 & $\mathrm{U}$ & K. QWPLTEEK. I \\
\hline$\overline{378}$ & $26-33$ & 515.757 & 1029.500 & 1029.513 & -12.3 & 0 & 34 & 0.00036 & 1 & $\mathrm{U}$ & K. QWPLTEEK. I \\
\hline$\overline{874}$ & $26-35$ & 424.562 & 1270.665 & 1270.692 & -21.1 & 1 & 35 & 0.00032 & 1 & $\mathrm{U}$ & K. QWPLTEEKIK. A \\
\hline$\overline{875}$ & $26-35$ & 424.562 & 1270.665 & 1270.692 & -21.0 & 1 & 49 & $1.3 e-05$ & 1 & $\mathrm{U}$ & K. QWPLTEEKIK. A \\
\hline$\checkmark \overline{2412}$ & $34-49$ & 470.239 & 1876.926 & 1876.964 & -19.9 & 2 & 99 & 1. $2 e-10$ & 1 & $\mathrm{U}$ & $\begin{array}{l}\text { K. IKALVEICTEMEKEGK. I } \\
+ \text { Carbamidomethyl } \\
\text { (C) }\end{array}$ \\
\hline$\square \underline{2413}$ & $34-49$ & 470.240 & 1876.931 & 1876.964 & -17.3 & 2 & 31 & 0.00072 & 1 & $\mathrm{U}$ & $\begin{array}{l}\text { K. IKALVEICTEMEKEGK. I } \\
+ \text { Carbamidomethyl } \\
\begin{array}{l}\text { (C) }\end{array}\end{array}$ \\
\hline$\triangle \underline{2415}$ & $34-49$ & 626.657 & 1876.950 & 1876.964 & -7.40 & 2 & 61 & $8.6 e-07$ & 1 & $\mathrm{U}$ & 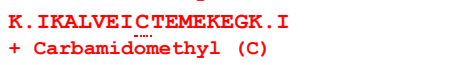 \\
\hline$\nearrow^{\prime 992}$ & $36-46$ & 661.820 & 1321.625 & 1321.626 & -0.24 & 0 & 60 & $1 e-06$ & 1 & $\mathrm{U}$ & $\begin{array}{l}\text { K.ALVEICTEMEK.E } \\
+ \text { Carbamidomethyl } \\
\text { (C) }\end{array}$ \\
\hline 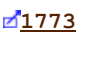 & $36-49$ & 546.261 & 1635.763 & 1635.785 & -13.5 & 1 & 76 & $2.6 e-08$ & 1 & $\mathrm{U}$ & $\begin{array}{l}\text { K. ALVEICTEMEKEGK. I } \\
+ \text { Carbamidomethyl } \\
\text { (C) }\end{array}$ \\
\hline$\checkmark \underline{1774}$ & $36-49$ & 546.261 & 1635.763 & 1635.785 & -13.5 & 1 & 44 & $3.9 e-05$ & 1 & $\mathrm{U}$ & $\begin{array}{l}\text { K. ALVEICTEMEKEGK. I } \\
+ \text { Carbamidomethyl } \\
\text { (C) }\end{array}$ \\
\hline$\triangle 1775$ & $36-49$ & 546.263 & 1635.768 & 1635.785 & -10.5 & 1 & 93 & $4.7 e-10$ & 1 & $\mathrm{U}$ & $\begin{array}{l}\text { K. ALVEICTEMEKEGK. I } \\
+ \text { Carbamidomethyl } \\
\text { (C) }\end{array}$ \\
\hline$\square \underline{1776}$ & $36-49$ & 546.263 & 1635.768 & 1635.785 & -10.5 & 1 & 107 & $1.8 e-11$ & 1 & $\mathrm{U}$ & $\begin{array}{l}\text { K.ALVEICTEMEKEGK.I } \\
+ \text { Carbamidomethyl } \\
\text { (C) }\end{array}$ \\
\hline$\square 1777$ & $36-49$ & 546.263 & 1635.768 & 1635.785 & -10.5 & 1 & 84 & 3. $9 e-09$ & 1 & $\mathrm{U}$ & $\begin{array}{l}\text { K. ALVEICTEMEKEGK. I } \\
+ \text { Carbamidomethyl } \\
\begin{array}{l}\text { (C) }\end{array}\end{array}$ \\
\hline$\triangle 1821$ & $36-49$ & 551.594 & 1651.761 & 1651.780 & -11.4 & 1 & 86 & $2.5 e-09$ & 1 & $\mathrm{U}$ & $\begin{array}{l}\text { K.ALVEICTEMEKEGK.I } \\
+ \text { Carbamidomethyl } \\
\text { (C); Oxidation (M) }\end{array}$ \\
\hline$\triangle \underline{1822}$ & $36-49$ & 551.594 & 1651.761 & 1651.780 & -11.3 & 1 & 106 & $2.3 e-11$ & 1 & $\mathrm{U}$ & $\begin{array}{l}\text { K.ALVEICTEMEKEGK.I } \\
+ \text { Carbamidomethyl } \\
\begin{array}{l}\text { (C) ; Oxidation (M) }\end{array}\end{array}$ \\
\hline$\triangle 1823$ & $36-49$ & 551.594 & 1651.761 & 1651.780 & -11.3 & 1 & 100 & $9.2 e-11$ & 1 & $\mathrm{U}$ & $\begin{array}{l}\text { K.ALVEICTEMEKEGK.I } \\
+ \text { Carbamidomethyl } \\
\begin{array}{l}\text { (C); Oxidation (M) }\end{array}\end{array}$ \\
\hline
\end{tabular}




\begin{tabular}{|c|c|c|c|c|}
\hline Query & Start - End & Observed & $M r($ expt) & $\operatorname{Mr}($ calc) \\
\hline$\varangle^{\prime 2648}$ & $36-52$ & 491.999 & 1963.965 & 1963.996 \\
\hline$\varangle \underline{2649}$ & $36-52$ & 492.000 & 1963.969 & 1963.996 \\
\hline$\triangle \underline{2650}$ & $36-52$ & 983.014 & 1964.013 & 1963.996 \\
\hline$\varangle \underline{2652}$ & $36-52$ & 655.995 & 1964.963 & 1963.996 \\
\hline$\llbracket \underline{2679}$ & $36-52$ & 495.997 & 1979.958 & 1979.991 \\
\hline$\triangle 2680$ & $36-52$ & 495.997 & 1979.959 & 1979.991 \\
\hline$\varangle^{2681}$ & $36-52$ & 495.998 & 1979.962 & 1979.991 \\
\hline$\triangle \underline{2699}$ & $50-67$ & 994.528 & 1987.042 & 1987.078 \\
\hline$\varangle \underline{999}$ & $50-67$ & 663.362 & 1987.065 & 1987.078 \\
\hline$\varangle 2967$ & $50-68$ & 529.792 & 2115.140 & 2115.173 \\
\hline$\square \underline{1845}$ & $53-67$ & 830.441 & 1658.868 & 1658.867 \\
\hline$\triangle^{\prime 1846}$ & $53-67$ & 830.444 & 1658.873 & 1658.867 \\
\hline$\triangle 1847$ & $53-67$ & 830.444 & 1658.874 & 1658.867 \\
\hline $\mathbb{0}^{\prime 1848}$ & $53-67$ & 830.445 & 1658.875 & 1658.867 \\
\hline$\triangle 1849$ & $53-67$ & 830.445 & 1658.875 & 1658.867 \\
\hline$\triangle^{\prime 1850}$ & $53-67$ & 830.445 & 1658.876 & 1658.867 \\
\hline$\triangle 1851$ & $53-67$ & 830.445 & 1658.876 & 1658.867 \\
\hline$\triangle 1852$ & $53-67$ & 830.445 & 1658.876 & 1658.867 \\
\hline$\underline{1853}$ & $53-67$ & 830.445 & 1658.876 & 1658.867 \\
\hline$\triangle 1854$ & $53-67$ & 830.446 & 1658.877 & 1658.867 \\
\hline$\underline{1855}$ & $53-67$ & 830.446 & 1658.877 & 1658.867 \\
\hline 1856 & $53-67$ & 830.446 & 1658.877 & 1658.867 \\
\hline$\checkmark 1857$ & $53-67$ & 830.446 & 1658.877 & 1658.867 \\
\hline 1858 & $53-67$ & 830.446 & 1658.877 & 1658.867 \\
\hline$\overline{1859}$ & $53-67$ & 830.446 & 1658.877 & 1658.867 \\
\hline 1860 & $53-67$ & 830.446 & 1658.877 & 1658.867 \\
\hline$\checkmark 1861$ & $53-67$ & 830.446 & 1658.877 & 1658.867 \\
\hline$\longdiv { 1 8 6 2 }$ & $53-67$ & 830.446 & 1658.878 & 1658.867 \\
\hline$\checkmark 1863$ & $53-67$ & 830.446 & 1658.878 & 1658.867 \\
\hline$\overline{1864}$ & $53-67$ & 830.446 & 1658.878 & 1658.867 \\
\hline$\checkmark 1865$ & $53-67$ & 830.446 & 1658.878 & 1658.867 \\
\hline 1866 & $53-67$ & 830.446 & 1658.878 & 1658.867 \\
\hline$\triangle 1867$ & $53-67$ & 830.446 & 1658.878 & 1658.867 \\
\hline$\overline{1869}$ & $53-67$ & 830.447 & 1658.879 & 1658.867 \\
\hline 1870 & $53-67$ & 830.447 & 1658.880 & 1658.867 \\
\hline$\overline{1871}$ & $53-67$ & 830.448 & 1658.881 & 1658.867 \\
\hline$\overline{1872}$ & $53-67$ & 830.448 & 1658.881 & 1658.867 \\
\hline$\overline{1873}$ & $53-67$ & 830.448 & 1658.881 & 1658.867 \\
\hline$\overline{1874}$ & $53-67$ & 830.448 & 1658.882 & 1658.867 \\
\hline$\overline{1875}$ & $53-67$ & 830.945 & 1659.876 & 1658.867 \\
\hline$\overline{1876}$ & $53-67$ & 830.953 & 1659.892 & 1658.867 \\
\hline$\longdiv { 2 2 3 2 }$ & $53-68$ & 596.658 & 1786.953 & 1786.962 \\
\hline$\overleftarrow{2233}$ & $53-68$ & 596.658 & 1786.953 & 1786.962 \\
\hline$\widetilde{2515}$ & $53-69$ & 639.357 & 1915.049 & 1915.057 \\
\hline$\checkmark 57$ & $76-81$ & 389.225 & 776.436 & 776.454 \\
\hline$\nabla \overline{842}$ & $76-85$ & 421.237 & 1260.688 & 1260.719 \\
\hline$\overline{917}$ & $77-86$ & 430.573 & 1288.697 & 1288.725 \\
\hline$\overline{919}$ & $77-86$ & 430.573 & 1288.698 & 1288.725 \\
\hline$\overline{9920}$ & $77-86$ & 430.573 & 1288.699 & 1288.725 \\
\hline$\overline{921}$ & $77-86$ & 645.366 & 1288.717 & 1288.725 \\
\hline$\overline{\square 922}$ & $77-86$ & 645.366 & 1288.717 & 1288.725 \\
\hline$\nabla^{\prime} 928$ & $77-86$ & 645.867 & 1289.720 & 1288.725 \\
\hline$\checkmark 3114$ & $86-104$ & 731.724 & 2192.151 & 2191.154 \\
\hline 3301 & $86-105$ & 580.816 & 2319.235 & 2319.249 \\
\hline 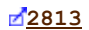 & $87-104$ & 679.354 & 2035.041 & 2035.053 \\
\hline 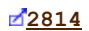 & $87-104$ & 679.355 & 2035.043 & 2035.053 \\
\hline 22816 & $87-104$ & 679.357 & 2035.048 & 2035.053 \\
\hline 22817 & $87-104$ & 679.358 & 2035.051 & 2035.053 \\
\hline 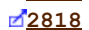 & $87-104$ & 679.359 & 2035.054 & 2035.053 \\
\hline$\widetilde{2819}$ & $87-104$ & 679.359 & 2035.055 & 2035.053 \\
\hline 1037 & $87-104$ & 679.362 & 2035.063 & 2035.053 \\
\hline$\varangle \underline{2820}$ & $87-104$ & 1018.547 & 2035.080 & 2035.053 \\
\hline$\varpi^{2} \underline{2821}$ & $87-104$ & 1018.547 & 2035.080 & 2035.053 \\
\hline$\overline{3049}$ & $87-105$ & 541.788 & 2163.122 & 2163.148 \\
\hline$\checkmark 3050$ & $87-105$ & 541.788 & 2163.122 & 2163.148 \\
\hline$\triangle^{3} 3051$ & $87-105$ & 722.057 & 2163.150 & 2163.148 \\
\hline$\triangleleft^{\prime 3052}$ & $87-105$ & 722.057 & 2163.150 & 2163.148 \\
\hline$\nearrow^{\prime} 3248$ & $87-106$ & 573.813 & 2291.221 & 2291.243 \\
\hline$\triangle^{\prime 3249}$ & $87-106$ & 764.753 & 2291.238 & 2291.243 \\
\hline$\overline{3615}$ & $107-129$ & 650.835 & 2599.310 & 2599.317 \\
\hline$\triangle^{\prime 3} 329$ & $108-128$ & 1172.590 & 2343.165 & 2343.127 \\
\hline$\triangle^{\prime} 3501$ & $108-129$ & 824.753 & 2471.237 & 2471.222 \\
\hline$\varangle^{\prime 3502}$ & $108-129$ & 824.753 & 2471.237 & 2471.222 \\
\hline$\triangle^{\prime} 3503$ & $108-129$ & 824.753 & 2471.237 & 2471.222 \\
\hline$\varangle^{\prime 3504}$ & $108-129$ & 824.753 & 2471.237 & 2471.222 \\
\hline$\underline{3505}$ & $108-129$ & 824.753 & 2471.237 & 2471.222 \\
\hline 3506 & $108-129$ & 824.753 & 2471.238 & 2471.222 \\
\hline
\end{tabular}

\begin{tabular}{|c|c|c|c|c|c|c|}
\hline ppm & M & Score & Expect & Rank & $\mathrm{U}$ & Peptide \\
\hline-15.4 & 2 & 109 & $1.2 e-11$ & 1 & $\ddot{U}$ & $\begin{array}{l}\text { K. ALVEICTEMEKEGKISK. I } \\
+ \text { Carbamidomethy } 1 \\
\text { (C) }\end{array}$ \\
\hline-13.7 & 2 & 87 & $2.1 e-09$ & 1 & $\mathrm{U}$ & $\begin{array}{l}\text { K. ALVEICTEMEKEGKISK. I } \\
+ \text { Carbamidomethyl } \\
\begin{array}{ll}\text { (C) }\end{array}\end{array}$ \\
\hline 8.64 & 2 & 97 & $1.8 e-10$ & 1 & $\mathrm{U}$ & $\begin{array}{l}\text { K. ALVEICTEMEKEGKISK. I } \\
+ \text { Carbamidomethyl } \\
\begin{array}{ll}\text { (C) }\end{array}\end{array}$ \\
\hline 492 & 2 & 72 & $5.8 e-08$ & 1 & $\mathrm{U}$ & $\begin{array}{l}\text { K. ALVEICTEMEKEGKISK. I } \\
+ \text { Carbamidomethy } 1 \\
\text { (C) }\end{array}$ \\
\hline-16.3 & 2 & 92 & $5.7 e-10$ & 1 & $\mathrm{U}$ & $\begin{array}{l}\text { K.ALVEICTEMEKEGKISK. I } \\
+ \text { Carbamidomethyl } \\
\begin{array}{ll}\text { (C); Oxidation (M) }\end{array}\end{array}$ \\
\hline-16.1 & 2 & 67 & $2 e-07$ & 1 & $\mathrm{U}$ & $\begin{array}{l}\text { K.ALVEICTEMEKEGKISK.I } \\
+ \text { Carbamidomethyl } \\
\begin{array}{l}\text { (C); Oxidation (M) }\end{array}\end{array}$ \\
\hline-14.5 & 2 & 83 & $5 e-09$ & 1 & $\mathrm{U}$ & $\begin{array}{l}\text { K.ALVEICTEMEKEGKISK. I } \\
+ \text { + Carbamidomethyl } \\
\begin{array}{ll}\text { (C); Oxidation (M) }\end{array}\end{array}$ \\
\hline-18.3 & 1 & 82 & $6.2 e-09$ & 1 & $\mathrm{U}$ & K. ISKIGPENPYNTPVFAIK. K \\
\hline-6.57 & 1 & 121 & $8.7 e-13$ & 1 & $\mathrm{U}$ & K. ISKIGPENPYNTPVFAIK. K \\
\hline-15.4 & 2 & 91 & $8.7 e-10$ & 1 & $\mathrm{U}$ & K. ISKIGPENPYNTPVFAIKK. K \\
\hline 0.56 & 0 & 81 & $8.5 e-09$ & 1 & $\mathrm{U}$ & K. IGPENPYNTPVFAIK. K \\
\hline 3.69 & 0 & 76 & $2.4 e-08$ & 1 & $\mathrm{U}$ & K. IGPENPYNTPVFAIK . K \\
\hline 4.17 & 0 & 88 & $1.7 e-09$ & 1 & $\mathrm{U}$ & K. IGPENPYNTPVFAIK. K \\
\hline 5.01 & 0 & 47 & $2.1 \mathrm{e}-05$ & 1 & $\mathrm{U}$ & K. IGPENPYNTPVFAIK. K \\
\hline 5.21 & 0 & 68 & $1.6 e-07$ & 1 & $\mathrm{U}$ & K. IGPENPYNTPVFAIK. K \\
\hline 5.25 & 0 & 23 & 0.0048 & 1 & $\mathrm{U}$ & K. IGPENPYNTPVFAIK. K \\
\hline 5.51 & 0 & 79 & $1.2 \mathrm{e}-08$ & 1 & $\mathrm{U}$ & K. IGPENPYNTPVFAIK. K \\
\hline 5.59 & 0 & 88 & $1.6 e-09$ & 1 & $\mathrm{U}$ & K. IGPENPYNTPVFAIK. K \\
\hline 5.70 & 0 & 75 & $2.9 e-08$ & 1 & $\mathrm{U}$ & K. IGPENPYNTPVFAIK. K \\
\hline 6.03 & 0 & 59 & $1.2 \mathrm{e}-06$ & 1 & $\mathrm{U}$ & K. IGPENPYNTPVFAIK. K \\
\hline 6.04 & 0 & 72 & $7 e-08$ & 1 & $\mathrm{U}$ & K. IGPENPYNTPVFAIK. K \\
\hline 6.11 & 0 & 73 & $4.9 e-08$ & 1 & $\mathrm{U}$ & K. IGPENPYNTPVFAIK . K \\
\hline 6.23 & 0 & 46 & $2.4 e-05$ & 1 & $\mathrm{U}$ & K. IGPENPYNTPVFAIK. K \\
\hline 6.33 & 0 & 55 & $3.3 e-06$ & 1 & $\mathrm{U}$ & K. IGPENPYNTPVFAIK. K \\
\hline 6.40 & 0 & 85 & $3.2 e-09$ & 1 & $\mathrm{U}$ & K. IGPENPYNTPVFAIK. K \\
\hline 6.41 & 0 & 79 & $1.2 \mathrm{e}-08$ & 1 & $\mathrm{U}$ & K. IGPENPYNTPVFAIK . $\mathrm{K}$ \\
\hline 6.42 & 0 & 52 & $6.4 e-06$ & 1 & $\mathrm{U}$ & K. IGPENPYNTPVFAIK. K \\
\hline 6.48 & 0 & 100 & $1.1 \mathrm{e}-10$ & 1 & $\mathrm{U}$ & K. IGPENPYNTPVFAIK . $\mathrm{K}$ \\
\hline 6.51 & 0 & 88 & $1.6 e-09$ & 1 & $\mathrm{U}$ & K. IGPENPYNTPVFAIK . K \\
\hline 6.65 & 0 & 70 & $1 e-07$ & 1 & $\mathrm{U}$ & K. IGPENPYNTPVFAIK. $\mathrm{K}$ \\
\hline 6.65 & 0 & 78 & $1.5 e-08$ & 1 & $\mathrm{U}$ & K. IGPENPYNTPVFAIK. K \\
\hline 6.65 & 0 & 75 & $3.1 e-08$ & 1 & $\mathrm{U}$ & K. IGPENPYNTPVFAIK . K \\
\hline 6.70 & 0 & 75 & $3 e-08$ & 1 & $\mathrm{U}$ & K. IGPENPYNTPVFAIK. $\mathrm{K}$ \\
\hline 7.45 & 0 & 66 & $2.5 e-07$ & 1 & $\mathrm{U}$ & K. IGPENPYNTPVFAIK. K \\
\hline 7.85 & 0 & 70 & $9 e-08$ & 1 & $\mathrm{U}$ & K. IGPENPYNTPVFAIK . K \\
\hline 8.52 & 0 & 88 & $1.8 \mathrm{e}-09$ & 1 & $\mathrm{U}$ & K. IGPENPYNTPVFAIK . K \\
\hline 8.58 & 0 & 92 & $5.6 e-10$ & 1 & $\mathrm{U}$ & K. IGPENPYNTPVFAIK. K \\
\hline 8.58 & 0 & 98 & $1.7 e-10$ & 1 & $\mathrm{U}$ & K. IGPENPYNTPVFAIK . K \\
\hline 9.12 & 0 & 55 & $2.9 e-06$ & 1 & $\mathrm{U}$ & K. IGPENPYNTPVFAIK . K \\
\hline 609 & 0 & 70 & $8.9 e-08$ & 1 & $\mathrm{U}$ & K. IGPENPYNTPVFAIK. K \\
\hline 618 & 0 & 92 & $5.8 e-10$ & 1 & $\mathrm{U}$ & K. IGPENPYNTPVFAIK. K \\
\hline-4.84 & 1 & 79 & $1.4 \mathrm{e}-08$ & 1 & $\mathrm{U}$ & K. IGPENPYNTPVFAIKK . K \\
\hline-4.77 & 1 & 95 & $3.2 e-10$ & 1 & $\mathrm{U}$ & K. IGPENPYNTPVFAIKK. K \\
\hline-4.18 & 2 & 26 & 0.0025 & 1 & $\mathrm{U}$ & K. IGPENPYNTPVFAIKKK. D \\
\hline-24.0 & 1 & 40 & 0.0001 & 1 & $\mathrm{U}$ & R.KLVDFR.E \\
\hline-24.8 & 2 & 35 & 0.00034 & 1 & $\mathrm{U}$ & R. KLVDFRELNK. R \\
\hline-21.5 & 2 & 42 & $6.2 e-05$ & 1 & $\mathrm{U}$ & K.LVDFRELNKR.T \\
\hline-20.7 & 2 & 23 & 0.0056 & 1 & $\mathrm{U}$ & K. LVDFRELNKR. T \\
\hline-20.7 & 2 & 68 & $1.6 e-07$ & 1 & $\mathrm{U}$ & K. LVDFRELNKR.T \\
\hline-6.67 & 2 & 36 & 0.00025 & 1 & $\mathrm{U}$ & K. LVDFRELNKR. T \\
\hline-6.67 & 2 & 36 & 0.00023 & 1 & $\mathrm{U}$ & K. LVDFRELNKR.T \\
\hline 772 & 2 & 26 & 0.0027 & 1 & $\mathrm{U}$ & K. LVDFRELNKR. T \\
\hline 455 & 1 & 24 & 0.0039 & 1 & $\mathrm{U}$ & K. RTQDFWEVQLGIPHPAGLK . K \\
\hline-5.88 & 2 & 43 & $5 e-05$ & 1 & $\mathrm{U}$ & K. RTQDFWEVQLGIPHPAGLKK . K \\
\hline-5.99 & 0 & 58 & $1.7 e-06$ & 1 & $\mathrm{U}$ & R. TQDFWEVQLGI PHPAGLK. K \\
\hline-5.02 & 0 & 34 & 0.00041 & 1 & $\mathrm{U}$ & R. TQDFWEVQLGIPHPAGLK. K \\
\hline-2.45 & 0 & 49 & $1.2 \mathrm{e}-05$ & 1 & $\mathrm{U}$ & R. TQDFWEVQLGI PHPAGLK. K \\
\hline-0.73 & 0 & 67 & $2.1 \mathrm{e}-07$ & 1 & $\mathrm{U}$ & R. TQDFWEVQLGIPHPAGLK. K \\
\hline 0.82 & 0 & 100 & $8.9 e-11$ & 1 & $\mathrm{U}$ & R. TQDFWEVQLGI PHPAGLK. K \\
\hline 0.88 & 0 & 63 & $5.3 e-07$ & 1 & $\mathrm{U}$ & R. TQDFWEVQLGI PHPAGLK . K \\
\hline 5.02 & 0 & 76 & $2.5 e-08$ & 1 & $\mathrm{U}$ & R. TQDFWEVQLGI PHPAGLK. K \\
\hline 13.6 & 0 & 36 & 0.00023 & 1 & $\mathrm{U}$ & R. TQDFWEVQLGI PHPAGLK. K \\
\hline 13.6 & 0 & 86 & $2.5 e-09$ & 1 & $\mathrm{U}$ & R. TQDFWEVQLGIPHPAGLK. K \\
\hline-12.0 & 1 & 37 & 0.00019 & 1 & $\mathrm{U}$ & R. TQDFWEVQLGI PHPAGLKK . K \\
\hline-11.9 & 1 & 28 & 0.0018 & 1 & $\mathrm{U}$ & R. TQDFWEVQLGIPHPAGLKK. K \\
\hline 1.14 & 1 & 71 & $8.4 e-08$ & 1 & $\mathrm{U}$ & R. TQDFWEVQLGI PHPAGLKK . K \\
\hline 1.14 & 1 & 83 & $4.9 e-09$ & 1 & $\mathrm{U}$ & R. TQDFWEVQLGI PHPAGLKK . K \\
\hline-9.47 & 2 & 41 & $8.7 e-05$ & 1 & $\mathrm{U}$ & R. TQDFWEVQLGIPHPAGLKKK . K \\
\hline-2.24 & 2 & 42 & $6.5 e-05$ & 1 & $\mathrm{U}$ & R. TQDFWEVQLGIPHPAGLKKK . K \\
\hline-2.63 & 2 & 96 & $2.4 e-10$ & 1 & $\mathrm{U}$ & K.KSVTVLDVGDAYFSVPLDEDFRK.Y \\
\hline 16.0 & 0 & 68 & $1.7 e-07$ & 1 & $\mathrm{U}$ & K. SVTVLDVGDAYFSVPLDEDFR. K \\
\hline 6.12 & 1 & 50 & $1.1 \mathrm{e}-05$ & 1 & $\mathrm{U}$ & K. SVTVLDVGDAYFSVPLDEDFRK. Y \\
\hline 6.16 & 1 & 20 & 0.0092 & 1 & $\mathrm{U}$ & K. SVTVLDVGDAYFSVPLDEDFRK. Y \\
\hline 6.19 & 1 & 144 & $3.6 e-15$ & 1 & $\mathrm{U}$ & K. SVTVLDVGDAYFSVPLDEDFRK. Y \\
\hline 6.19 & 1 & 42 & $7 e-05$ & 1 & $\mathrm{U}$ & K. SVTVLDVGDAYFSVPLDEDFRK. Y \\
\hline 6.19 & 1 & 134 & $3.6 e-14$ & 1 & $\mathrm{U}$ & K. SVTVLDVGDAYFSVPLDEDFRK. Y \\
\hline 6.62 & 1 & 87 & $1.8 \mathrm{e}-09$ & 1 & $\mathrm{U}$ & K.SVTVLDVGDAYFSVPLDEDFRK.Y \\
\hline
\end{tabular}




\begin{tabular}{|c|c|c|c|c|c|c|c|c|c|c|c|}
\hline Query & Start - End & Observed & $\operatorname{Mr}(\operatorname{expt})$ & $\operatorname{Mr}(\mathrm{calc})$ & ppm & $\mathbf{M}$ & Score & Expect & Rank & $\mathrm{U}$ & Peptide \\
\hline$\nearrow^{\prime 3508}$ & $108-129$ & 825.082 & 2472.225 & 2471.222 & 406 & 1 & 53 & $5.2 e-06$ & 1 & $\mathrm{U}$ & K. SVTVLDVGDAYFSVPLDEDFRK. Y \\
\hline$\nearrow^{\prime 3} \underline{076}$ & $108-146$ & 1087.576 & 4346.274 & 4346.175 & 22.8 & 2 & 45 & $3.2 \mathrm{e}-05$ & 1 & $\mathrm{U}$ & K.SVTVLDVGDAYFSVPLDEDFRKYTAFTIPSINNETPGIR.Y \\
\hline$\triangle \underline{4089}$ & $108-146$ & 1087.817 & 4347.240 & 4346.175 & 245 & 2 & 73 & $4.6 e-08$ & 1 & $\mathrm{U}$ & K. SVTVLDVGDAYFSVPLDEDFRKYTAFTIPSINNETPGIR.Y \\
\hline$\varangle \underline{2771}$ & $129-146$ & 674.693 & 2021.058 & 2021.058 & -0.062 & 1 & 39 & 0.00013 & 1 & $\mathrm{U}$ & R. KYTAFTIPSINNETPGIR.Y \\
\hline$\varangle \check{2772}$ & $129-146$ & 1011.536 & 2021.058 & 2021.058 & -0.0094 & 1 & 76 & $2.3 e-08$ & 1 & $\mathrm{U}$ & R. KYTAFTIPSINNETPGIR.Y \\
\hline$\square \underline{2773}$ & $129-146$ & 1011.551 & 2021.087 & 2021.058 & 14.1 & 1 & 80 & $9.6 e-09$ & 1 & $\mathrm{U}$ & R.KYTAFTIPSINNETPGIR.Y \\
\hline$\checkmark \underline{4011}$ & $129-157$ & 850.692 & 3398.738 & 3397.746 & 292 & 2 & 58 & $1.6 e-06$ & 1 & $\mathrm{U}$ & R.KYTAFTIPSINNETPGIRYQYNVLPQGWK.G \\
\hline$\checkmark 2437$ & $130-146$ & 631.992 & 1892.953 & 1892.963 & -5.23 & 0 & 54 & $3.9 e-06$ & 1 & $\mathrm{U}$ & K.YTAFTIPSINNETPGIR.Y \\
\hline$\checkmark ゙ \underline{2438}$ & $130-146$ & 631.993 & 1892.958 & 1892.963 & -2.62 & 0 & 82 & $6.5 e-09$ & 1 & $\mathrm{U}$ & K.YTAFTIPSINNETPGIR.Y \\
\hline$\longdiv { 2 4 3 9 }$ & $130-146$ & 947.494 & 1892.974 & 1892.963 & 5.44 & 0 & 54 & $4.5 e-06$ & 1 & $\mathrm{U}$ & K.YTAFTIPSINNETPGIR.Y \\
\hline$\checkmark \underline{2440}$ & $130-146$ & 947.496 & 1892.978 & 1892.963 & 7.81 & 0 & 83 & $5 e-09$ & 1 & $\mathrm{U}$ & K.YTAFTIPSINNETPGIR.Y \\
\hline$\square^{2442}$ & $130-146$ & 947.497 & 1892.980 & 1892.963 & 9.00 & 0 & 46 & $2.7 e-05$ & 1 & $\mathrm{U}$ & K.YTAFTIPSINNETPGIR.Y \\
\hline$\square^{2} \underline{443}$ & $130-146$ & 947.498 & 1892.981 & 1892.963 & 9.26 & 0 & 80 & $9.7 e-09$ & 1 & $\mathrm{U}$ & K.YTAFTIPSINNETPGIR.Y \\
\hline$\checkmark 2444$ & $130-146$ & 947.498 & 1892.981 & 1892.963 & 9.36 & 0 & 57 & $2 e-06$ & 1 & $\mathrm{U}$ & K.YTAFTIPSINNETPGIR.Y \\
\hline$\nearrow^{\prime 2445}$ & $130-146$ & 947.498 & 1892.981 & 1892.963 & 9.45 & 0 & 48 & $1.7 e-05$ & 1 & U & K.YTAFTIPSINNETPGIR.Y \\
\hline$\square^{2446}$ & $130-146$ & 947.498 & 1892.982 & 1892.963 & 9.83 & 0 & 63 & $4.6 e-07$ & 1 & U & K.YTAFTIPSINNETPGIR.Y \\
\hline$\nabla \underline{2447}$ & $130-146$ & 947.498 & 1892.982 & 1892.963 & 9.96 & 0 & 65 & $3.2 e-07$ & 1 & $\mathrm{U}$ & K.YTAFTIPSINNETPGIR.Y \\
\hline$\nabla^{\prime 2448}$ & $130-146$ & 947.498 & 1892.982 & 1892.963 & 9.98 & 0 & 56 & $2.8 e-06$ & 1 & $\mathrm{U}$ & K.YTAFTIPSINNETPGIR.Y \\
\hline$\checkmark 2450$ & $130-146$ & 947.499 & 1892.983 & 1892.963 & 10.3 & 0 & 40 & $9.2 e-05$ & 1 & $\mathrm{U}$ & K.YTAFTIPSINNETPGIR.Y \\
\hline$\varpi^{2451}$ & $130-146$ & 947.499 & 1892.983 & 1892.963 & 10.6 & 0 & 61 & $8.3 e-07$ & 1 & $\mathrm{U}$ & K.YTAFTIPSINNETPGIR.Y \\
\hline$\varangle^{2} 2452$ & $130-146$ & 947.499 & 1892.984 & 1892.963 & 10.8 & 0 & 81 & $8.7 e-09$ & 1 & $\mathrm{U}$ & K.YTAFTIPSINNETPGIR.Y \\
\hline$\varangle^{2453}$ & $130-146$ & 947.499 & 1892.984 & 1892.963 & 11.2 & 0 & 48 & $1.7 e-05$ & 1 & U & K.YTAFTIPSINNETPGIR.Y \\
\hline$\checkmark 2454$ & $130-146$ & 947.500 & 1892.984 & 1892.963 & 11.2 & 0 & 76 & $2.4 e-08$ & 1 & $\mathrm{U}$ & K.YTAFTIPSINNETPGIR.Y \\
\hline$\widetilde{2455}$ & $130-146$ & 947.500 & 1892.985 & 1892.963 & 11.5 & 0 & 56 & $2.7 e-06$ & 1 & $\mathrm{U}$ & K.YTAFTIPSINNETPGIR.Y \\
\hline$\checkmark 2456$ & $130-146$ & 947.500 & 1892.985 & 1892.963 & 11.6 & 0 & 51 & $8.6 e-06$ & 1 & $\mathrm{U}$ & K.YTAFTIPSINNETPGIR.Y \\
\hline$\checkmark \underline{2458}$ & $130-146$ & 947.501 & 1892.987 & 1892.963 & 12.8 & 0 & 35 & 0.00034 & 1 & $\mathrm{U}$ & K.YTAFTIPSINNETPGIR.Y \\
\hline$\checkmark 2459$ & $130-146$ & 947.502 & 1892.989 & 1892.963 & 13.5 & 0 & 59 & $1.2 e-06$ & 1 & $\mathrm{U}$ & K.YTAFTIPSINNETPGIR.Y \\
\hline$\checkmark \underline{2460}$ & $130-146$ & 947.502 & 1892.989 & 1892.963 & 13.5 & 0 & 89 & $1.2 e-09$ & 1 & $\mathrm{U}$ & K.YTAFTIPSINNETPGIR.Y \\
\hline$\checkmark 2461$ & $130-146$ & 947.502 & 1892.989 & 1892.963 & 13.6 & 0 & 97 & $1.9 e-10$ & 1 & $\mathrm{U}$ & K.YTAFTIPSINNETPGIR.Y \\
\hline$\varangle 2462$ & $130-146$ & 947.503 & 1892.991 & 1892.963 & 14.9 & 0 & 34 & 0.00041 & 1 & $\mathrm{U}$ & K.YTAFTIPSINNETPGIR.Y \\
\hline$\checkmark 2463$ & $130-146$ & 947.504 & 1892.993 & 1892.963 & 15.9 & 0 & 49 & $1.3 e-05$ & 1 & $\mathrm{U}$ & K.YTAFTIPSINNETPGIR.Y \\
\hline$\square 2464$ & $130-146$ & 947.995 & 1893.975 & 1892.963 & 534 & 0 & 74 & $3.7 e-08$ & 1 & $\mathrm{U}$ & K.YTAFTIPSINNETPGIR.Y \\
\hline$\square \underline{2468}$ & $130-146$ & 948.006 & 1893.997 & 1892.963 & 546 & 0 & 21 & 0.0081 & 1 & $\mathrm{U}$ & K.YTAFTIPSINNETPGIR.Y \\
\hline 3989 & $130-157$ & 1090.908 & 3269.701 & 3269.651 & 15.4 & 1 & 104 & $3.8 e-11$ & 1 & $\mathrm{U}$ & K.YTAFTIPSINNETPGIRYQYNVLPQGWK.G \\
\hline$\checkmark \underline{4093}$ & $130-169$ & 1127.091 & 4504.333 & 4504.253 & 17.9 & 2 & 44 & $4.3 e-05$ & 1 & $\mathrm{U}$ & K. YTAFTIPSINNETPGIRYQYNVLPQGWKGSPAIFQSSMTK. \\
\hline$\widetilde{1146}$ & $147-157$ & 698.351 & 1394.688 & 1394.698 & -7.62 & 0 & 38 & 0.00023 & 1 & $\mathrm{U}$ & R. YQYNVLPQGWK.G \\
\hline$\widetilde{1147}$ & $147-157$ & 698.353 & 1394.692 & 1394.698 & -4.32 & 0 & 32 & 0.0011 & 1 & $\mathrm{U}$ & R. YQYNVLPQGWK.G \\
\hline$\sigma^{\prime 1148}$ & $147-157$ & 698.354 & 1394.694 & 1394.698 & -2.81 & 0 & 42 & 0.00011 & 1 & $\mathrm{U}$ & R. YQYNVLPQGWK.G \\
\hline$\sigma^{1149}$ & $147-157$ & 698.355 & 1394.694 & 1394.698 & -2.71 & 0 & 26 & 0.0027 & 1 & U & R. YQYNVLPQGWK.G \\
\hline$\overline{1150}$ & $147-157$ & 698.355 & 1394.695 & 1394.698 & -2.21 & 0 & 29 & 0.0014 & 1 & U & R.YQYNVLPQGWK.G \\
\hline$\nabla^{\prime 1151}$ & $147-157$ & 698.356 & 1394.697 & 1394.698 & -0.61 & 0 & 28 & 0.0017 & 1 & U & R.YQYNVLPQGWK.G \\
\hline$\mho^{\prime 1152}$ & $147-157$ & 698.356 & 1394.697 & 1394.698 & -0.61 & 0 & 40 & 0.00011 & 1 & $\mathrm{U}$ & R. YQYNVLPQGWK.G \\
\hline$\checkmark 1153$ & $147-157$ & 698.356 & 1394.698 & 1394.698 & -0.51 & 0 & 33 & 0.00089 & 1 & $\mathrm{U}$ & R. YQYNVLPQGWK.G \\
\hline$\checkmark 1154$ & $147-157$ & 698.356 & 1394.698 & 1394.698 & -0.13 & 0 & 42 & $5.9 e-05$ & 1 & $\mathrm{U}$ & R.YQYNVLPQGWK.G \\
\hline$\widetilde{1156}$ & $147-157$ & 698.357 & 1394.699 & 1394.698 & 0.76 & 0 & 29 & 0.0012 & 1 & $\mathrm{U}$ & R. YQYNVLPQGWK.G \\
\hline$\triangle 1157$ & $147-157$ & 698.357 & 1394.699 & 1394.698 & 0.80 & 0 & 27 & 0.003 & 1 & U & R. YQYNVLPQGWK.G \\
\hline$\triangle^{\prime 1158}$ & $147-157$ & 698.357 & 1394.699 & 1394.698 & 0.80 & 0 & 54 & $4.4 \mathrm{e}-06$ & 1 & $\mathrm{U}$ & R. YQYNVLPQGWK.G \\
\hline$\sigma^{\prime 1159}$ & $147-157$ & 698.357 & 1394.699 & 1394.698 & 0.84 & 0 & 29 & 0.0013 & 1 & $\mathrm{U}$ & R. YQYNVLPQGWK.G \\
\hline$\widetilde{1160}$ & $147-157$ & 698.357 & 1394.700 & 1394.698 & 1.36 & 0 & 37 & 0.0002 & 1 & $\mathrm{U}$ & R. YQYNVLPQGWK.G \\
\hline$\sigma^{\prime 1161}$ & $147-157$ & 698.358 & 1394.701 & 1394.698 & 1.82 & 0 & 24 & 0.0036 & 1 & $\mathrm{U}$ & R. YQYNVLPQGWK.G \\
\hline$\sigma^{\prime 1162}$ & $147-157$ & 698.358 & 1394.701 & 1394.698 & 1.85 & 0 & 53 & $5.6 e-06$ & 1 & $\mathrm{U}$ & R. YQYNVLPQGWK.G \\
\hline$\sigma^{1163}$ & $147-157$ & 698.359 & 1394.703 & 1394.698 & 3.25 & 0 & 35 & 0.0005 & 1 & U & R. YQYNVLPQGWK.G \\
\hline$\checkmark 1165$ & $147-157$ & 698.359 & 1394.703 & 1394.698 & 3.64 & 0 & 29 & 0.0013 & 1 & $\mathrm{U}$ & R. YQYNVLPQGWK.G \\
\hline$\overline{1166}$ & $147-157$ & 698.360 & 1394.705 & 1394.698 & 4.71 & 0 & 31 & 0.0014 & 1 & U & R.YQYNVLPQGWK.G \\
\hline$\overline{1167}$ & $147-157$ & 698.360 & 1394.705 & 1394.698 & 5.14 & 0 & 25 & 0.0046 & 1 & U & R. YQYNVLPQGWK.G \\
\hline$\checkmark 1168$ & $147-157$ & 698.362 & 1394.709 & 1394.698 & 7.84 & 0 & 39 & 0.00019 & 1 & $\mathrm{U}$ & R. YQYNVLPQGWK.G \\
\hline$\checkmark 1169$ & $147-157$ & 698.362 & 1394.710 & 1394.698 & 8.59 & 0 & 46 & $3.7 e-05$ & 1 & U & R. YQYNVLPQGWK.G \\
\hline$\sigma^{1170}$ & $147-157$ & 698.850 & 1395.686 & 1394.698 & 708 & 0 & 58 & $1.4 e-06$ & 1 & $\mathrm{U}$ & R. YQYNVLPQGWK.G \\
\hline$\checkmark 1171$ & $147-157$ & 698.856 & 1395.697 & 1394.698 & 716 & 0 & 29 & 0.0013 & 1 & $\mathrm{U}$ & R. YQYNVLPQGWK.G \\
\hline$\mho^{\prime 1172}$ & $147-157$ & 698.856 & 1395.698 & 1394.698 & 717 & 0 & 25 & 0.0033 & 1 & $\mathrm{U}$ & R. YQYNVLPQGWK.G \\
\hline$\overline{1173}$ & $147-157$ & 698.857 & 1395.699 & 1394.698 & 718 & 0 & 27 & 0.0018 & 1 & U & R. YQYNVLPQGWK.G \\
\hline$\overline{1175}$ & $147-157$ & 698.860 & 1395.705 & 1394.698 & 722 & 0 & 26 & 0.0023 & 1 & U & R. YQYNVLPQGWK.G \\
\hline 3639 & $147-169$ & 877.447 & 2629.321 & 2629.300 & 7.87 & 1 & 111 & $7.8 e-12$ & 1 & U & R. YQYNVLPQGWKGSPAIFQSSMTK. I \\
\hline$\checkmark \underline{3640}$ & $147-169$ & 877.447 & 2629.321 & 2629.300 & 7.87 & 1 & 118 & $1.5 e-12$ & 1 & $\mathrm{U}$ & R. YQYNVLPQGWKGSPAIFQSSMTK. I \\
\hline$\underline{3653}$ & $147-169$ & 882.779 & 2645.314 & 2645.295 & 7.28 & 1 & 102 & $6.6 e-11$ & 1 & $\mathrm{U}$ & $\begin{array}{l}\text { R.YQYNVLPQGWKGSPAIFQSSMTK. I } \\
+ \text { Oxidation (M) }\end{array}$ \\
\hline$\square^{810}$ & $158-169$ & 627.308 & 1252.602 & 1252.612 & -7.92 & 0 & 40 & $9.8 e-05$ & 1 & $\mathrm{U}$ & K.GSPAIFQSSMTK. I \\
\hline$\nabla^{811}$ & $158-169$ & 627.308 & 1252.602 & 1252.612 & -7.92 & 0 & 65 & $2.8 e-07$ & 1 & $\mathrm{U}$ & K.GSPAIFQSSMTK. I \\
\hline$\nabla^{\prime 812}$ & $158-169$ & 627.310 & 1252.606 & 1252.612 & -5.04 & 0 & 28 & 0.0015 & 1 & $\mathrm{U}$ & K.GSPAIFQSSMTK. I \\
\hline$\widetilde{813}$ & $158-169$ & 627.310 & 1252.606 & 1252.612 & -4.96 & 0 & 84 & $3.9 e-09$ & 1 & $\mathrm{U}$ & K.GSPAIFQSSMTK. I \\
\hline$\checkmark \underline{814}$ & $158-169$ & 627.310 & 1252.606 & 1252.612 & -4.96 & 0 & 84 & $4.3 e-09$ & 1 & U & K.GSPAIFQSSMTK. I \\
\hline$\varangle^{\prime 815}$ & $158-169$ & 627.310 & 1252.606 & 1252.612 & -4.96 & 0 & 88 & $1.7 e-09$ & 1 & $\mathrm{U}$ & K.GSPAIFQSSMTK. I \\
\hline$\varpi^{8} \mathbf{8 1 6}$ & $158-169$ & 627.311 & 1252.607 & 1252.612 & -3.82 & 0 & 21 & 0.0084 & 1 & $\mathrm{U}$ & K.GSPAIFQSSMTK. I \\
\hline$\varangle^{\prime 817}$ & $158-169$ & 627.311 & 1252.608 & 1252.612 & -3.37 & 0 & 46 & $2.8 e-05$ & 1 & U & K.GSPAIFQSSMTK. I \\
\hline$\varangle \underline{819}$ & $158-169$ & 627.314 & 1252.614 & 1252.612 & 1.68 & 0 & 49 & $1.5 e-05$ & 1 & $\mathrm{U}$ & K.GSPAIFQSSMTK.I \\
\hline$\square^{821}$ & $158-169$ & 627.320 & 1252.625 & 1252.612 & 9.85 & 0 & 32 & 0.0007 & 1 & $\mathrm{U}$ & K.GSPAIFQSSMTK. I \\
\hline$\overline{822}$ & $158-169$ & 627.324 & 1252.633 & 1252.612 & 16.5 & 0 & 23 & 0.0054 & 1 & $\mathrm{U}$ & K.GSPAIFQSSMTK. I \\
\hline$\triangle 859$ & $158-169$ & 423.866 & 1268.577 & 1268.607 & -23.5 & 0 & 44 & $4.1 e-05$ & 1 & $\mathrm{U}$ & $\begin{array}{l}\text { K.GSPAIFQSSMTK.I } \\
+ \text { Oxidation (M) }\end{array}$ \\
\hline$\triangle \underline{861}$ & $158-169$ & 635.308 & 1268.601 & 1268.607 & -4.66 & 0 & 41 & $8.6 e-05$ & 1 & $\mathrm{U}$ & $\begin{array}{l}\text { K.GSPAIFQSSMTK.I } \\
+ \text { oxidation (M) }\end{array}$ \\
\hline$\triangle \check{862}$ & $158-169$ & 635.308 & 1268.601 & 1268.607 & -4.66 & 0 & 67 & $1.9 e-07$ & 1 & $\mathrm{U}$ & $\begin{array}{l}\text { K.GSPAIFQSSMTK.I } \\
+ \text { oxidation }(\bar{M})\end{array}$ \\
\hline
\end{tabular}




\begin{tabular}{|c|c|c|c|c|c|c|c|c|c|c|c|}
\hline Query & Start - End & Observed & $M r(\exp t)$ & $\mathrm{Mr}$ (calc) & ppm & $\mathrm{M}$ & Score & Expect & Rank & $\mathrm{U}$ & Peptide \\
\hline 8786 & $158-169$ & 635.308 & 1268.601 & 1268.607 & -4.66 & $\dddot{0}$ & 86 & $2.3 e-09$ & 1 & U & $\begin{array}{l}\text { K.GSPAIFQSSMTK.I } \\
+ \text { Oxidation }(\mathrm{M})\end{array}$ \\
\hline 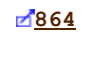 & $158-169$ & 635.308 & 1268.601 & 1268.607 & -4.66 & 0 & 82 & $6.9 e-09$ & 1 & $\mathrm{U}$ & $\begin{array}{l}\text { K.GSPAIFQSSMTK.I } \\
+ \text { Oxidation }(\mathrm{M})\end{array}$ \\
\hline$\varangle^{\prime 866}$ & $158-169$ & 635.809 & 1269.604 & 1268.607 & 786 & 0 & 64 & $3.9 e-07$ & 1 & $\mathrm{U}$ & $\begin{array}{l}\text { K.GSPAIFQSSMTK.I } \\
+ \text { oxidation (M) }\end{array}$ \\
\hline$\checkmark \underline{152}$ & $170-176$ & 437.764 & 873.513 & 873.532 & -21.7 & 1 & 21 & 0.0071 & 1 & $\mathrm{U}$ & K. ILEPFKK.Q \\
\hline$\overline{153}$ & $170-176$ & 437.764 & 873.513 & 873.532 & -21.7 & 1 & 27 & 0.0018 & 1 & $\mathrm{U}$ & K. ILEPFKK.Q \\
\hline$\underline{154}$ & $170-176$ & 437.765 & 873.515 & 873.532 & -19.7 & 1 & 24 & 0.0042 & 1 & $\mathrm{U}$ & K. ILEPFKK.Q \\
\hline$\overline{155}$ & $170-176$ & 437.765 & 873.515 & 873.532 & -19.6 & 1 & 46 & $2.4 e-05$ & 1 & $\mathrm{U}$ & K. ILEPFKK.Q \\
\hline$\overline{157}$ & $170-176$ & 437.766 & 873.517 & 873.532 & -17.8 & 1 & 34 & 0.00044 & 1 & $\mathrm{U}$ & K. ILEPFKK. $Q$ \\
\hline$\overline{158}$ & $170-176$ & 437.766 & 873.517 & 873.532 & -17.8 & 1 & 35 & 0.00035 & 1 & $\mathrm{U}$ & K. ILEPFKK.Q \\
\hline$\checkmark \underline{4072}$ & $170-202$ & 787.600 & 3932.964 & 3932.944 & 4.99 & 2 & 58 & $1.7 e-06$ & 1 & $\mathrm{U}$ & $\begin{array}{l}\text { K. ILEPFKKQNPDIVICQYMDDLYVGSDLEIGQHR. T } \\
+ \text { Carbamidomethy } 1 \text { (C) }\end{array}$ \\
\hline$\underline{3975}$ & $176-202$ & 802.389 & 3205.526 & 3205.517 & 2.68 & 1 & 125 & $3 e-13$ & 1 & $\mathrm{U}$ & $\begin{array}{l}\text { K. KQNPDIVICQYMDDLYVGSDLEIGQHR.T } \\
\begin{array}{ll}\text { + Carbamidomethyl } & \text { (C) }\end{array}\end{array}$ \\
\hline$\checkmark \mathbf{3 9 2 3}$ & $177-202$ & 770.365 & 3077.429 & 3077.422 & 2.17 & 0 & 98 & $1.4 e-10$ & 1 & $\mathrm{U}$ & $\begin{array}{l}\text { K. QNPDIVICQYMDDLYVGSDLEIGQHR.T } \\
+ \text { Carbamidomethy } 1 \\
\text { (C) }\end{array}$ \\
\hline$\checkmark \underline{3925}$ & $177-202$ & 1027.172 & 3078.494 & 3077.422 & 348 & 0 & 41 & $7.5 e-05$ & 1 & $\mathrm{U}$ & $\begin{array}{l}\text { K. QNPDIVICQYMDDLYVGSDLEIGQHR. T } \\
+ \text { Carbamidomethy } 1 \\
\begin{array}{ll}\text { (C) } & \end{array}\end{array}$ \\
\hline$\checkmark \underline{3931}$ & $177-202$ & 1032.133 & 3093.378 & 3093.417 & -12.6 & 0 & 116 & $2.3 e-12$ & 1 & $\mathrm{U}$ & $\begin{array}{l}\text { K. QNPDIVICQYMDDLYVGSDLEIGQHR.T } \\
\begin{array}{lll}\text { + Carbamidomethyl } & \text { (C); Oxidation } & \text { (M) }\end{array}\end{array}$ \\
\hline$\checkmark \underline{165}$ & $203-209$ & 444.753 & 887.491 & 887.508 & -19.1 & 1 & 34 & 0.00044 & 1 & $\mathrm{U}$ & R.TKIEELR.Q \\
\hline$\nabla \underline{166}$ & $203-209$ & 444.753 & 887.491 & 887.508 & -19.1 & 1 & 58 & $1.6 e-06$ & 1 & $\mathrm{U}$ & R.TKIEELR.Q \\
\hline 凹̛1516 & $203-214$ & 384.721 & 1534.856 & 1534.894 & -24.6 & 2 & 81 & $7.9 e-09$ & 1 & $\mathrm{U}$ & R. TKIEELRQHLLR. W \\
\hline$\checkmark \underline{1517}$ & $203-214$ & 512.631 & 1534.870 & 1534.894 & -15.7 & 2 & 38 & 0.00016 & 1 & $\mathrm{U}$ & R. TKIEELRQHLLR.W \\
\hline ¿゙1518 & $203-214$ & 512.632 & 1534.873 & 1534.894 & -13.9 & 2 & 36 & 0.00023 & 1 & $\mathrm{U}$ & R. TKIEELRQHLLR. W \\
\hline$\checkmark \underline{1519}$ & $203-214$ & 512.632 & 1534.873 & 1534.894 & -13.9 & 2 & 61 & $8.3 e-07$ & 1 & $\mathrm{U}$ & R. TKIEELRQHLLR.W \\
\hline ð゙1520 & $203-214$ & 512.632 & 1534.875 & 1534.894 & -12.7 & 2 & 46 & $2.8 e-05$ & 1 & $\mathrm{U}$ & R. TKIEELRQHLLR. W \\
\hline$\triangle 1521$ & $203-214$ & 512.632 & 1534.875 & 1534.894 & -12.7 & 2 & 56 & $2.7 e-06$ & 1 & $\mathrm{U}$ & R.TKIEELRQHLLR.W \\
\hline$\checkmark \underline{1522}$ & $203-214$ & 512.632 & 1534.875 & 1534.894 & -12.7 & 2 & 58 & $1.7 e-06$ & 1 & $\mathrm{U}$ & R. TKIEELRQHLLR.W \\
\hline$\varangle \underline{963}$ & $205-214$ & 436.248 & 1305.723 & 1305.752 & -21.9 & 1 & 46 & $2.3 e-05$ & 1 & $\mathrm{U}$ & K. IEELRQHLLR. W \\
\hline$\varangle \underline{964}$ & $205-214$ & 436.249 & 1305.725 & 1305.752 & -20.5 & 1 & 56 & $2.8 e-06$ & 1 & $\mathrm{U}$ & K. IEELRQHLLR. W \\
\hline$\varangle \underline{965}$ & $205-214$ & 436.249 & 1305.726 & 1305.752 & -19.9 & 1 & 57 & $2 e-06$ & 1 & $\mathrm{U}$ & K. IEELRQHLLR. W \\
\hline$\varangle \underline{966}$ & $205-214$ & 653.877 & 1305.739 & 1305.752 & -9.66 & 1 & 54 & $4.3 e-06$ & 1 & $\mathrm{U}$ & K. IEELRQHLLR. W \\
\hline$\checkmark \underline{192}$ & $215-222$ & 459.232 & 916.449 & 916.465 & -17.9 & 0 & 34 & 0.00036 & 1 & $\mathrm{U}$ & R.WGLTTPDK. K \\
\hline$\varangle \underline{396}$ & $215-223$ & 523.281 & 1044.547 & 1044.560 & -12.9 & 1 & 37 & 0.00022 & 1 & $\mathrm{U}$ & R.WGLTTPDKK. H \\
\hline$\checkmark ̛ \underline{1255}$ & $215-226$ & 480.257 & 1437.748 & 1437.773 & -17.2 & 2 & 67 & $2 e-07$ & 1 & $\mathrm{U}$ & R. WGLTTPDKKHQK.E \\
\hline$\varangle \underline{971}$ & $242-252$ & 655.377 & 1308.740 & 1308.744 & -3.41 & 0 & 30 & 0.00096 & 1 & $\mathrm{U}$ & K.WTVQPIVLPEK.D \\
\hline$\checkmark \underline{663}$ & $263-278$ & 596.333 & 1785.978 & 1786.014 & -20.4 & 1 & 40 & $9.2 e-05$ & 1 & $\mathrm{U}$ & K. LVGKLNWASQIYPGIK.V \\
\hline$₫ ゚ 2214$ & $263-278$ & 596.335 & 1785.983 & 1786.014 & -17.3 & 1 & 44 & $3.7 e-05$ & 1 & $\mathrm{U}$ & K.LVGKLNWASQIYPGIK.V \\
\hline$\varangle \underline{2215}$ & $263-278$ & 596.335 & 1785.983 & 1786.014 & -17.3 & 1 & 76 & $2.3 e-08$ & 1 & $\mathrm{U}$ & K.LVGKLNWASQIYPGIK.V \\
\hline$\overline{6664}$ & $263-278$ & 596.336 & 1785.985 & 1786.014 & -16.1 & 1 & 62 & $6.7 e-07$ & 1 & $\mathrm{U}$ & K. LVGKLNWASQIYPGIK.V \\
\hline$\triangle \underline{2216}$ & $263-278$ & 596.336 & 1785.985 & 1786.014 & -16.1 & 1 & 42 & $5.6 e-05$ & 1 & $\mathrm{U}$ & K. LVGKLNWASQIYPGIK.V \\
\hline$\overline{2217}$ & $263-278$ & 596.337 & 1785.989 & 1786.014 & -14.2 & 1 & 69 & $1.2 e-07$ & 1 & $\mathrm{U}$ & K. LVGKLNWASQIYPGIK.V \\
\hline$\lcm{2218}$ & $263-278$ & 596.338 & 1785.991 & 1786.014 & -12.9 & 1 & 31 & 0.00086 & 1 & $\mathrm{U}$ & K. LVGKLNWASQIYPGIK.V \\
\hline$\checkmark \underline{2219}$ & $263-278$ & 596.338 & 1785.992 & 1786.014 & -12.6 & 1 & 40 & 0.0001 & 1 & $\mathrm{U}$ & K. LVGKLNWASQIYPGIK.V \\
\hline$\overline{2220}$ & $263-278$ & 596.338 & 1785.993 & 1786.014 & -11.8 & 1 & 31 & 0.00085 & 1 & $\mathrm{U}$ & K.LVGKLNWASQIYPGIK.V \\
\hline$\checkmark 665$ & $263-278$ & 596.338 & 1785.994 & 1786.014 & -11.5 & 1 & 89 & $1.4 \mathrm{e}-09$ & 1 & $\mathrm{U}$ & K. LVGKLNWASQIYPGIK.V \\
\hline 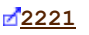 & $263-278$ & 596.339 & 1785.994 & 1786.014 & -11.3 & 1 & 65 & $3.5 e-07$ & 1 & $\mathrm{U}$ & K. LVGKLNWASQIYPGIK.V \\
\hline$\overleftarrow{2222}$ & $263-278$ & 596.339 & 1785.995 & 1786.014 & -10.7 & 1 & 45 & $3.1 e-05$ & 1 & $\mathrm{U}$ & K. LVGKLNWASQIYPGIK.V \\
\hline$\longdiv { 2 2 2 3 }$ & $263-278$ & 596.339 & 1785.996 & 1786.014 & -10.3 & 1 & 93 & $4.6 e-10$ & 1 & $\mathrm{U}$ & K. LVGKLNWASQIYPGIK.V \\
\hline$\longdiv { 2 2 2 4 }$ & $263-278$ & 596.339 & 1785.996 & 1786.014 & -10.3 & 1 & 69 & $1.3 e-07$ & 1 & $\mathrm{U}$ & K. LVGKLNWASQIYPGIK.V \\
\hline$\overline{2226}$ & $263-278$ & 596.340 & 1785.999 & 1786.014 & -8.59 & 1 & 69 & $1.3 e-07$ & 1 & $\mathrm{U}$ & K. LVGKLNWASQIYPGIK.V \\
\hline$\overleftarrow{2228}$ & $263-278$ & 596.342 & 1786.003 & 1786.014 & -6.36 & 1 & 51 & $8.6 e-06$ & 1 & $\mathrm{U}$ & K. LVGKLNWASQIYPGIK.V \\
\hline$\longdiv { 2 2 2 9 }$ & $263-278$ & 596.342 & 1786.005 & 1786.014 & -5.28 & 1 & 85 & $3.1 e-09$ & 1 & $\mathrm{U}$ & K. LVGKLNWASQIYPGIK.V \\
\hline$\overline{2230}$ & $263-278$ & 596.342 & 1786.005 & 1786.014 & -5.28 & 1 & 93 & $5 e-10$ & 1 & $\mathrm{U}$ & K. LVGKLNWASQIYPGIK.V \\
\hline$\overline{666}$ & $263-278$ & 596.344 & 1786.009 & 1786.014 & -2.76 & 1 & 30 & 0.00097 & 1 & $\mathrm{U}$ & K. LVGKLNWASQIYPGIK.V \\
\hline$\square \underline{2236}$ & $263-278$ & 596.667 & 1786.980 & 1786.014 & 541 & 1 & 68 & $1.4 e-07$ & 1 & $\mathrm{U}$ & K.LVGKLNWASQIYPGIK.V \\
\hline$\longdiv { 2 8 3 3 }$ & $263-280$ & 511.296 & 2041.156 & 2041.184 & -13.7 & 2 & 84 & $4.3 e-09$ & 1 & $\mathrm{U}$ & K. LVGKLNWASQIYPGIKVR.Q \\
\hline$\overline{2834}$ & $263-280$ & 681.400 & 2041.179 & 2041.184 & -2.34 & 2 & 27 & 0.0018 & 1 & $\mathrm{U}$ & K. LVGKLNWASQIYPGIKVR.Q \\
\hline$\overline{1102}$ & $267-278$ & 695.368 & 1388.722 & 1388.745 & -16.8 & 0 & 41 & $9.5 e-05$ & 1 & $\mathrm{U}$ & K. LNWASQIYPGIK.V \\
\hline$\overline{1105}$ & $267-278$ & 695.374 & 1388.733 & 1388.745 & -9.02 & 0 & 74 & $5.2 e-08$ & 1 & $\mathrm{U}$ & K. LNWASQIYPGIK.V \\
\hline$\overline{1106}$ & $267-278$ & 695.375 & 1388.735 & 1388.745 & -7.46 & 0 & 51 & $1 e-05$ & 1 & $\mathrm{U}$ & K. LNWASQIYPGIK.V \\
\hline$\overline{1107}$ & $267-278$ & 695.375 & 1388.736 & 1388.745 & -6.99 & 0 & 56 & $2.5 e-06$ & 1 & $\mathrm{U}$ & K. LNWASQIYPGIK.V \\
\hline$\overline{1108}$ & $267-278$ & 695.377 & 1388.739 & 1388.745 & -4.77 & 0 & 66 & $3.6 e-07$ & 1 & $\mathrm{U}$ & K. LNWASQIYPGIK.V \\
\hline$\overline{1109}$ & $267-278$ & 695.377 & 1388.739 & 1388.745 & -4.31 & 0 & 44 & $4 e-05$ & 1 & $\mathrm{U}$ & K. LNWASQIYPGIK.V \\
\hline$\overline{1110}$ & $267-278$ & 695.377 & 1388.739 & 1388.745 & -4.25 & 0 & 37 & 0.00019 & 1 & $\mathrm{U}$ & K. LNWASQIYPGIK.V \\
\hline$\overline{1111}$ & $267-278$ & 695.377 & 1388.740 & 1388.745 & -3.76 & 0 & 56 & $2.7 e-06$ & 1 & $\mathrm{U}$ & K. LNWASQIYPGIK.V \\
\hline$\overline{1112}$ & $267-278$ & 695.378 & 1388.741 & 1388.745 & -3.39 & 0 & 56 & $3.1 e-06$ & 1 & $\mathrm{U}$ & K. LNWASQIYPGIK.V \\
\hline$\overline{1113}$ & $267-278$ & 695.378 & 1388.741 & 1388.745 & -2.77 & 0 & 39 & 0.00013 & 1 & $\mathrm{U}$ & K. LNWASQIYPGIK.V \\
\hline$\overline{1114}$ & $267-278$ & 695.378 & 1388.741 & 1388.745 & -2.74 & 0 & 50 & $9.7 e-06$ & 1 & $\mathrm{U}$ & K. LNWASQIYPGIK.V \\
\hline$\overline{1115}$ & $267-278$ & 695.378 & 1388.742 & 1388.745 & -2.26 & 0 & 50 & $1.1 e-05$ & 1 & $\mathrm{U}$ & K. LNWASQIYPGIK.V \\
\hline$\overline{1116}$ & $267-278$ & 695.378 & 1388.742 & 1388.745 & -2.16 & 0 & 52 & $5.7 e-06$ & 1 & $\mathrm{U}$ & K. LNWASQIYPGIK.V \\
\hline$\overline{1117}$ & $267-278$ & 695.379 & 1388.743 & 1388.745 & -1.92 & 0 & 51 & $7.6 e-06$ & 1 & $\mathrm{U}$ & K. LNWASQIYPGIK.V \\
\hline$\overline{1118}$ & $267-278$ & 695.379 & 1388.743 & 1388.745 & -1.74 & 0 & 57 & $1.9 e-06$ & 1 & $\mathrm{U}$ & K. LNWASQIYPGIK.V \\
\hline$\overline{1119}$ & $267-278$ & 695.379 & 1388.744 & 1388.745 & -1.21 & 0 & 53 & $5.9 e-06$ & 1 & $\mathrm{U}$ & K. LNWASQIYPGIK.V \\
\hline$\overline{1120}$ & $267-278$ & 695.379 & 1388.744 & 1388.745 & -1.17 & 0 & 74 & $4.1 e-08$ & 1 & $\mathrm{U}$ & K. LNWASQIYPGIK.V \\
\hline$\overline{1122}$ & $267-278$ & 695.379 & 1388.744 & 1388.745 & -0.84 & 0 & 61 & $7.5 e-07$ & 1 & $\mathrm{U}$ & K. LNWASQIYPGIK.V \\
\hline$\overline{1123}$ & $267-278$ & 695.379 & 1388.744 & 1388.745 & -0.84 & 0 & 38 & 0.00017 & 1 & $\mathrm{U}$ & K. LNWASQIYPGIK.V \\
\hline$\overline{1124}$ & $267-278$ & 695.380 & 1388.745 & 1388.745 & -0.30 & 0 & 50 & $9.7 e-06$ & 1 & $\mathrm{U}$ & K. LNWASQIYPGIK.V \\
\hline 1125 & $267-278$ & 695.380 & 1388.745 & 1388.745 & -0.26 & 0 & 34 & 0.0004 & 1 & $\mathrm{U}$ & K. LNWASQIYPGIK.V \\
\hline$\overline{1126}$ & $267-278$ & 695.380 & 1388.746 & 1388.745 & 0.39 & 0 & 30 & 0.0011 & 1 & $\mathrm{U}$ & K. LNWASQIYPGIK.V \\
\hline 1127 & $267-278$ & 695.380 & 1388.746 & 1388.745 & 0.39 & 0 & 33 & 0.00046 & 1 & $\mathrm{U}$ & K. LNWASQIYPGIK.V \\
\hline
\end{tabular}




\begin{tabular}{|c|c|c|c|c|c|c|c|c|}
\hline Query & Start - End & Observed & $M r(\exp t)$ & $\operatorname{Mr}(\operatorname{calc})$ & ppm & $\mathbf{M}$ & Score & Expect \\
\hline 1128 & $267-278$ & 695.380 & 1388.746 & 1388.745 & 0.40 & 0 & 39 & 0.00012 \\
\hline$\checkmark 1129$ & $267-278$ & 695.380 & 1388.746 & 1388.745 & 0.45 & 0 & 58 & $1.4 e-06$ \\
\hline 1130 & $267-278$ & 695.380 & 1388.746 & 1388.745 & 0.45 & 0 & 67 & $2 e-07$ \\
\hline$\triangle 1131$ & $267-278$ & 695.380 & 1388.746 & 1388.745 & 0.52 & 0 & 37 & 0.0002 \\
\hline$\checkmark 1132$ & $267-278$ & 695.380 & 1388.746 & 1388.745 & 0.62 & 0 & 41 & $8.3 e-05$ \\
\hline$\triangle 1133$ & $267-278$ & 695.381 & 1388.748 & 1388.745 & 1.87 & 0 & 41 & $8.2 e-05$ \\
\hline$\checkmark 1134$ & $267-278$ & 695.381 & 1388.748 & 1388.745 & 1.89 & 0 & 53 & $4.5 e-06$ \\
\hline$\triangle 1135$ & $267-278$ & 695.383 & 1388.752 & 1388.745 & 4.56 & 0 & 70 & $1.1 \mathrm{e}-07$ \\
\hline$\triangle 1799$ & $267-280$ & 548.974 & 1643.900 & 1643.915 & -8.79 & 1 & 78 & $1.5 e-08$ \\
\hline$\checkmark 712$ & $281-290$ & 406.235 & 1215.682 & 1215.712 & -24.7 & 2 & 39 & 0.00011 \\
\hline$\underline{3189}$ & $291-310$ & 747.394 & 2239.161 & 2239.158 & 1.17 & 0 & 114 & $4 e-12$ \\
\hline$\triangle^{\prime} 3720$ & $291-314$ & 908.507 & 2722.498 & 2722.464 & 12.4 & 1 & 119 & $1.2 \mathrm{e}-12$ \\
\hline$\llbracket \underline{2404}$ & $311-326$ & 625.329 & 1872.964 & 1872.962 & 1.23 & 1 & 63 & $4.5 e-07$ \\
\hline$\checkmark 3775$ & $311-334$ & 696.874 & 2783.468 & 2783.475 & -2.27 & 2 & 110 & $1 e-11$ \\
\hline$\triangle^{\prime 3264}$ & $315-334$ & 576.049 & 2300.166 & 2300.169 & -1.18 & 1 & 60 & $1.1 \mathrm{e}-06$ \\
\hline$\longdiv { 3 2 6 5 }$ & $315-334$ & 767.731 & 2300.172 & 2300.169 & 1.18 & 1 & 99 & 1. $4 \mathrm{e}-10$ \\
\hline$\triangle \underline{215}$ & $327-334$ & 465.263 & 928.512 & 928.523 & -11.9 & 0 & 43 & $4.5 e-05$ \\
\hline$\llbracket \underline{2724}$ & $335-350$ & 1000.992 & 1999.969 & 1999.943 & 13.2 & 0 & 88 & $1.7 e-09$ \\
\hline$\nearrow^{\prime 3} 347$ & $335-353$ & 786.065 & 2355.174 & 2355.165 & 4.11 & 1 & 141 & $7.7 e-15$ \\
\hline$\checkmark 3348$ & $335-353$ & 786.401 & 2356.180 & 2355.165 & 431 & 1 & 74 & $3.6 e-08$ \\
\hline$\triangle^{3649}$ & $335-356$ & 661.337 & 2641.318 & 2641.329 & -4.29 & 2 & 69 & $1.2 e-07$ \\
\hline$ð^{\prime 2} \underline{781}$ & $360-377$ & 507.260 & 2025.009 & 2025.043 & -16.5 & 2 & 35 & 0.00035 \\
\hline$ð^{2} \underline{2782}$ & $360-377$ & 507.260 & 2025.009 & 2025.043 & -16.5 & 2 & 78 & $1.7 e-08$ \\
\hline$\varangle^{2} \underline{2783}$ & $360-377$ & 507.260 & 2025.010 & 2025.043 & -16.3 & 2 & 25 & 0.0032 \\
\hline$\varangle^{\prime 2} \underline{786}$ & $360-377$ & 676.019 & 2025.036 & 2025.043 & -3.11 & 2 & 94 & 4. $3 e-10$ \\
\hline$\square 2787$ & $360-377$ & 676.020 & 2025.037 & 2025.043 & -2.81 & 2 & 56 & $2.6 e-06$ \\
\hline 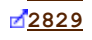 & $360-377$ & 511.260 & 2041.011 & 2041.037 & -13.1 & 2 & 71 & $8.1 e-08$ \\
\hline$\varangle^{\prime 2830}$ & $360-377$ & 511.260 & 2041.011 & 2041.037 & -13.0 & 2 & 22 & 0.0059 \\
\hline$\square \underline{2831}$ & $360-377$ & 681.349 & 2041.026 & 2041.037 & -5.46 & 2 & 98 & $1.7 e-10$ \\
\hline$\llbracket 2832$ & $360-377$ & 511.271 & 2041.055 & 2041.037 & 8.84 & 2 & 51 & $7.9 e-06$ \\
\hline$\nearrow^{\prime 2084}$ & $362-377$ & 580.304 & 1737.890 & 1737.901 & -6.39 & 1 & 76 & $2.7 e-08$ \\
\hline$ð^{20087}$ & $362-377$ & 435.723 & 1738.865 & 1737.901 & 555 & 1 & 109 & $1.4 \mathrm{e}-11$ \\
\hline$\llbracket \underline{2088}$ & $362-377$ & 580.632 & 1738.873 & 1737.901 & 559 & 1 & 49 & $1.2 e-05$ \\
\hline$\square 2089$ & $362-377$ & 870.456 & 1738.898 & 1737.901 & 574 & 1 & 37 & 0.00019 \\
\hline$\checkmark 3886$ & $362-388$ & 742.404 & 2965.587 & 2965.587 & 0.046 & 2 & 136 & $2.6 e-14$ \\
\hline$\checkmark 3888$ & $362-388$ & 742.652 & 2966.581 & 2965.587 & 335 & 2 & 35 & 0.00033 \\
\hline$\triangle 187$ & $370-377$ & 458.752 & 915.489 & 915.503 & -15.2 & 0 & 21 & 0.0078 \\
\hline$\checkmark 188$ & $370-377$ & 458.752 & 915.489 & 915.503 & -15.2 & 0 & 27 & 0.0019 \\
\hline$\checkmark 189$ & $370-377$ & 458.752 & 915.489 & 915.503 & -15.2 & 0 & 58 & $1.4 e-06$ \\
\hline$\triangle \underline{3021}$ & $370-388$ & 715.405 & 2143.192 & 2143.189 & 1.66 & 1 & 132 & $6.7 e-14$ \\
\hline$\longdiv { 3 0 2 2 }$ & $370-388$ & 715.734 & 2144.181 & 2143.189 & 463 & 1 & 76 & $2.4 e-08$ \\
\hline$\longdiv { 3 4 9 7 }$ & $370-391$ & 618.352 & 2469.378 & 2469.384 & -2.61 & 2 & 162 & $6.1 e-17$ \\
\hline$\overline{779}$ & $378-388$ & 623.850 & 1245.686 & 1245.697 & -8.65 & 0 & 70 & $1.1 e-07$ \\
\hline$\overline{780}$ & $378-388$ & 623.851 & 1245.687 & 1245.697 & -7.69 & 0 & 27 & 0.0019 \\
\hline$\overline{781}$ & $378-388$ & 623.852 & 1245.690 & 1245.697 & -5.62 & 0 & 73 & $4.8 e-08$ \\
\hline$\square \overline{782}$ & $378-388$ & 623.852 & 1245.690 & 1245.697 & -5.30 & 0 & 24 & 0.0037 \\
\hline$\overline{783}$ & $378-388$ & 623.852 & 1245.690 & 1245.697 & -5.23 & 0 & 69 & $1.4 \mathrm{e}-07$ \\
\hline$\square$ & $378-388$ & 623.852 & 1245.690 & 1245.697 & -5.21 & 0 & 82 & $6.9 e-09$ \\
\hline$\overline{785}$ & $378-388$ & 623.852 & 1245.690 & 1245.697 & -5.21 & 0 & 82 & $5.8 e-09$ \\
\hline$\triangle \overline{786}$ & $378-388$ & 623.852 & 1245.690 & 1245.697 & -5.18 & 0 & 49 & $1.4 \mathrm{e}-05$ \\
\hline$\triangle 787$ & $378-388$ & 623.853 & 1245.691 & 1245.697 & -4.97 & 0 & 44 & $3.8 e-05$ \\
\hline 788 & $378-388$ & 623.853 & 1245.692 & 1245.697 & -3.98 & 0 & 58 & $1.7 e-06$ \\
\hline$\overline{789}$ & $378-388$ & 623.854 & 1245.693 & 1245.697 & -3.27 & 0 & 61 & $8.9 e-07$ \\
\hline$\checkmark 790$ & $378-388$ & 623.854 & 1245.693 & 1245.697 & -3.02 & 0 & 73 & 4. $5 e-08$ \\
\hline$\checkmark \underline{792}$ & $378-388$ & 623.854 & 1245.694 & 1245.697 & -2.05 & 0 & 37 & 0.00022 \\
\hline 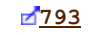 & $378-388$ & 623.855 & 1245.696 & 1245.697 & -0.59 & 0 & 71 & $7.5 e-08$ \\
\hline$\checkmark 799$ & $378-388$ & 624.356 & 1246.698 & 1245.697 & 804 & 0 & 41 & $7.6 e-05$ \\
\hline$\longdiv { 8 0 0 }$ & $378-388$ & 624.359 & 1246.703 & 1245.697 & 807 & 0 & 54 & $3.9 e-06$ \\
\hline$\triangle 1628$ & $378-391$ & 524.964 & 1571.869 & 1571.892 & -14.5 & 1 & 80 & $9 e-09$ \\
\hline$\triangle 1629$ & $378-391$ & 524.964 & 1571.870 & 1571.892 & -14.4 & 1 & 56 & $2.8 e-06$ \\
\hline$\triangle 1630$ & $378-391$ & 524.965 & 1571.872 & 1571.892 & -13.0 & 1 & 106 & $2.3 e-11$ \\
\hline$\triangle^{\prime 1631}$ & $378-391$ & 524.965 & 1571.874 & 1571.892 & -11.8 & 1 & 71 & $7.1 e-08$ \\
\hline$\triangle 1632$ & $378-391$ & 786.957 & 1571.899 & 1571.892 & 4.45 & 1 & 95 & $3.4 e-10$ \\
\hline$\triangle 151$ & $392-398$ & 437.273 & 872.532 & 872.548 & -18.8 & 1 & 39 & 0.00014 \\
\hline$\triangle 4095$ & $392-427$ & 1152.603 & 4606.383 & 4606.304 & 17.1 & 2 & 43 & 4. $9 e-05$ \\
\hline$\square \underline{3756}$ & $428-451$ & 923.808 & 2768.403 & 2768.381 & 7.90 & 1 & 43 & $4.7 e-05$ \\
\hline 3757 & $428-451$ & 923.808 & 2768.403 & 2768.381 & 8.08 & 1 & 20 & 0.0091 \\
\hline$\underline{3758}$ & $428-451$ & 923.810 & 2768.409 & 2768.381 & 10.3 & 1 & 37 & 0.00019 \\
\hline$\checkmark 3759$ & $428-451$ & 923.811 & 2768.410 & 2768.381 & 10.6 & 1 & 132 & $6.7 e-14$ \\
\hline$\triangle \underline{3762}$ & $428-451$ & 924.138 & 2769.394 & 2768.381 & 366 & 1 & 73 & $4.5 e-08$ \\
\hline$\checkmark 3944$ & $428-454$ & 782.650 & 3126.572 & 3126.566 & 1.78 & 2 & 91 & $8.9 e-10$ \\
\hline$\checkmark 3945$ & $428-454$ & 782.650 & 3126.572 & 3126.566 & 1.78 & 2 & 89 & $1.2 \mathrm{e}-09$ \\
\hline$\checkmark 3946$ & $428-454$ & 782.652 & 3126.578 & 3126.566 & 3.93 & 2 & 161 & $8.2 e-17$ \\
\hline$\checkmark 3947$ & $428-454$ & 782.653 & 3126.583 & 3126.566 & 5.49 & 2 & 52 & $5.8 e-06$ \\
\hline$\checkmark 3948$ & $428-454$ & 782.900 & 3127.572 & 3126.566 & 322 & 2 & 42 & $6.7 e-05$ \\
\hline$\longdiv { 3 9 4 9 }$ & $428-454$ & 782.900 & 3127.573 & 3126.566 & 322 & 2 & 106 & $2.8 e-11$ \\
\hline$\longdiv { 3 9 5 0 }$ & $428-454$ & 1043.532 & 3127.574 & 3126.566 & 322 & 2 & 27 & 0.002 \\
\hline$\longdiv { 3 9 5 1 }$ & $428-454$ & 782.903 & 3127.584 & 3126.566 & 326 & 2 & 43 & $5.1 e-05$ \\
\hline$\triangle \triangle^{3}$ & $435-454$ & 723.032 & 2166.073 & 2166.059 & 6 & 1 & 38 & 0.00014 \\
\hline
\end{tabular}

U. Peptide

U K. LNWASQIYPGIK.V

U K. LNWASQIYPGIK. V

U K. LNWASOIYPGIK. V

U K. LNWASQIYPGIK.V

U K. LNWASQIYPGIK.V

U K. LNWASQIYPGIK. V

U K. LNWASQIYPGIK. V

U K. LNWASQIYPGIK.V

U K. LNWASQIYPGIKVR. Q

J R.QLCKLLRGTK.A

+ Carbamidomethyl (C)

U K.ALTEVIPLTEEAELELAENR.E

K ALTEVIPLTEEAELELAENREILK. F

U R.EILKEPVHGVYYDPSK.D

U R.EILKEPVHGVYYDPSKDLIAEIQK.Q

U K.EPVHGVYYDPSKDLIAEIQK.Q

U K.EPVHGVYYDPSKDLIAEIQK.O

U K.DLIAEIQK.Q

U K.QGQGQWTYQIYQEPFK.N

U K.QGQGQWTYQIYQEPFKNLK . T

U K.QGQGQWTYQIYQEPFKNLK. T

U K.QGQGQWTYQIYQEPFKNLKTGK.Y

U R.MRGAHTNDVKQLTEAVQK. I

U R.MRGAHTNDVKOLTEAVOK. I

U R.MRGAHTNDVKQLTEAVQK. I

U R.MRGAHTNDVKQLTEAVQK. I

U R.MRGAHTNDVKOLTEAVOK. I

U R.MRGAHTNDVKQLTEAVQK. I

+ Oxidation (M)

U R. MRGAHTNDVKQLTEAVOK. I

+ Oxidation (M)

U R.MRGAHTNDVKQLTEAVQK. I

+ Oxidation (M)

U R.MRGAHTNDVKOLTEAVOK. I

+ Oxidation (M)

U R.GAHTNDVKQLTEAVQK. I

U R.GAHTNDVKQLTEAVQK. I

U R.GAHTNDVKQLTEAVQK. I

U R.GAHTNDVKQLTEAVQK. I

U R.GAHTNDVKQLTEAVQKITTESIVIWGK. T

U R.GAHTNDVKQLTEAVQKITTESIVIWGK. T

U K. QLTEAVQK. I

U K. QLTEAVQK. I

U K. QLTEAVQK. I

U K. OLTEAVOKITTESIVIWGK. T

U K.QLTEAVQKITTESIVIWGK. T

U K.QLTEAVQKITTESIVIWGKTPK.F

U K. ITTESIVIWGK. T

U K. ITTESIVIWGK. T

U K. ITTESIVIWGK.T

U K. ITTESIVIWGK.T

U K. ITTESIVIWGK. T

U K.ITTESIVIWGK.T

U K.ITTESIVIWGK.T

U K. ITTESIVIWGK. T

U K. ITTESIVIWGK.T

U K. ITTESIVIWGK.T

U K. ITTESIVIWGK. T

U K. ITTESIVIWGK. T

U K. ITTESIVIWGK.T

U K. ITTESIVIWGK. T

U K. ITTESIVIWGK. T

U K. ITTESIVIWGK.

U K. ITTESIVIWGKTPK.F

U K. ITTESIVIWGKTPK.

U K. ITTESIVIWGKTPK.

U K.ITTESIVIWGKTPK.F

U K. ITTESIVIWGKTPK. F

U K.FKLPIOK.E

U K. FKLPIQKETWETWWTEYWQATWIPEWEFVNTPPLVK. L

U K. LWYQLEKEPIVGAETFYVDGAANR.E

U K. LWYQLEKEPIVGAETFYVDGAANR . E

U K. LWYQLEKEPIVGAETFYVDGAANR. E

U K. LWYQLEKEPIVGAETFYVDGAANR. $E$

U K. LWYQLEKEPIVGAETFYVDGAANR . E

U K. LWYOLEKEPIVGAETFYVDGAANRETK. I

U K. LWYQLEKEPIVGAETFYVDGAANRETK. I

U K. LWYQLEKEPIVGAETFYVDGAANRETK. I

U K. LWYOLEKEPIVGAETFYVDGAANRETK. I

U K. LWYQLEKEPIVGAETFYVDGAANRETK. I

U K. LWYQLEKEPIVGAETFYVDGAANRETK. L

$U$ K. LWYOLEKEPIVGAETFYVDGAANRETK. I

$U$ U . LWYOLEKEPIVGAETFYVDGAANRETK. L

U K.EPIVGAETFYVDGAANRETK.L 


\begin{tabular}{|c|c|c|}
\hline Query & tart & $-\mathrm{Er}$ \\
\hline$\underline{1322}$ & 467 & -47 \\
\hline$\overline{1324}$ & 467 & - \\
\hline$\overline{\square 707}$ & 469 & \\
\hline-798 & 516 & \\
\hline$\widetilde{1265}$ & 532 & \\
\hline-627 & 534 & \\
\hline 628 & 534 & \\
\hline$\overline{629}$ & 534 & - \\
\hline 630 & 534 & \\
\hline$\checkmark 631$ & 534 & -5 \\
\hline$\triangle 632$ & 534 & - \\
\hline$\overline{633}$ & 534 & -5 \\
\hline 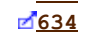 & 534 & -5 \\
\hline$\overline{637}$ & 534 & -5 \\
\hline$\overline{640}$ & 534 & - \\
\hline$\checkmark 641$ & 534 & - \\
\hline$\overline{642}$ & 534 & - \\
\hline '3835 & 534 & - \\
\hline$\checkmark 3837$ & 534 & -5 \\
\hline 3838 & 534 & -5 \\
\hline$\checkmark 355$ & 544 & -55 \\
\hline$\varangle^{\prime 2024}$ & 544 & -5 \\
\hline$\square^{2025}$ & 544 & -5 \\
\hline$\overline{2026}$ & 544 & - \\
\hline$\overline{\sigma^{553}}$ & 544 & - \\
\hline$\square 2030$ & 544 & -5 \\
\hline
\end{tabular}

Observed $\mathrm{Mr}$ (expt) $\mathrm{Mr}$ (calc) $\begin{array}{rlll}490.941 & 1469.800 & 1469.820\end{array}$ $\begin{array}{lll}490.941 & 1469.800 & 1469.820\end{array}$ $\begin{array}{lll}607.837 & 1213.659 & 1213.667\end{array}$ $\begin{array}{llll}624.356 & 1870.047 & 1870.041\end{array}$ $\begin{array}{llll}480.931 & 1439.770 & 1439.792\end{array}$ $\begin{array}{lll}395.217 & 1182.628 & 1182.655\end{array}$ $\begin{array}{llll}592.326 & 1182.637 & 1182.655\end{array}$ $\begin{array}{lll}592.329 & 1182.643 \quad 1182.655\end{array}$ $592.329 \quad 1182.643 \quad 1182.655$ $\begin{array}{llll}592.329 & 1182.644 & 1182.655\end{array}$ $\begin{array}{lll}592.330 & 1182.645 & 1182.655\end{array}$ $592.330 \quad 1182.645 \quad 1182.655$ $\begin{array}{llll}592.330 & 1182.645 & 1182.655\end{array}$ $\begin{array}{lll}592.331 & 1182.647 & 1182.655\end{array}$ $\begin{array}{lll}592.331 & 1182.648 & 1182.655\end{array}$ $\begin{array}{llll}592.331 & 1182.648 & 1182.655\end{array}$ $\begin{array}{llll}592.331 & 1182.648 & 1182.655\end{array}$ $\begin{array}{lll}576.314 & 2876.534 & 2876.566\end{array}$ $\begin{array}{lll}576.318 & 2876.551 \quad 2876.566\end{array}$ $\begin{array}{llll}959.874 & 2876.599 & 2876.566\end{array}$ $\begin{array}{llll}508.746 & 1015.477 & 1015.493\end{array}$ $571.643 \quad 1711.906 \quad 1711.922$ $571.643 \quad 1711.906 \quad 1711.922$ $571.643 \quad 1711.906 \quad 1711.922$ $571.644 \quad 1711.910 \quad 1711.922$ $571.974 \quad 1712.900 \quad 1711.922$

\begin{tabular}{rrr}
\multicolumn{1}{c}{ ppm } & M & Scor \\
-13.9 & 1 & 58 \\
-13.8 & 1 & 32 \\
-6.30 & 0 & 74 \\
3.01 & 1 & 42 \\
-15.8 & 1 & 60 \\
-22.6 & 0 & 42 \\
-14.9 & 0 & 26 \\
-10.1 & 0 & 35 \\
-9.95 & 0 & 33 \\
-9.29 & 0 & 41 \\
-8.56 & 0 & 28 \\
-8.38 & 0 & 24 \\
-8.21 & 0 & 29 \\
-6.79 & 0 & 28 \\
-6.14 & 0 & 43 \\
-6.14 & 0 & 50 \\
-5.58 & 0 & 30 \\
-11.1 & 2 & 34 \\
-5.20 & 2 & 112 \\
11.6 & 2 & 170 \\
-16.5 & 0 & 72 \\
-9.31 & 1 & 104 \\
-9.31 & 1 & 114 \\
-9.27 & 1 & 104 \\
-7.03 & 1 & 80 \\
571 & 1 & 70 \\
& &
\end{tabular}

Ppm M Score

Expect Rank 1. $7 e-06$ 0.00063

$3.7 e-08$ $6.6 e-05$ 9. $4 \mathrm{e}-07$ $5.8 e-05$ 0.0032 0.00031 0.00054

7. $5 e-05$

0.0016

0.0044

0.0011

0.0016

$5.6 e-05$

$1 \mathrm{e}-05$

0.001

0.00044

$6.5 e-12$

$1 \mathrm{e}-17$

6. $9 e-08$

4. $1 \mathrm{e}-11$

3. $6 e-12$

3. $7 e-11$

$1 e-08$

1. $1 \mathrm{e}-07$
Rank U. Peptide

1. R.QKVVPLTNTTNQK.T

R.QKVVPLTNTTNQK.T

1 U K.VVPLTNTTNQK.T

U K.SESELVNQIIEQLIKK.E

U K.EKVYLAWVPAHK.G

U K.VYLAWVPAHK.G

U K.VYLAWVPAHK.G

U K.VYLAWVPAHK.G

U K.VYLAWVPAHK.G

U K.VYLAWVPAHK.G

U K.VYLAWVPAHK.G

U K. VYLAWVPAHK. G

U K.VYLAWVPAHK.G

U K.VYLAWVPAHK.G

U K.VYLAWVPAHK.G

U K.VYLAWVPAHK. G

U K.VYLAWVPAHK.G

U K.VYLAWVPAHKGIGGNEQVDKLVSAGIR.K

U K.VYLAWVPAHKGIGGNEQVDKLVSAGIR.K

U K.VYLAWVPAHKGIGGNEQVDKLVSAGIR. K

U K.GIGGNEQVDK. L

U K.GIGGNEQVDKLVSAGIR. K

U K.GIGGNEOVDKLVSAGIR. K

U K.GIGGNEQVDKLVSAGIR.K

U K.GIGGNEQVDKLVSAGIR. K

U K.GIGGNEOVDKLVSAGIR.K

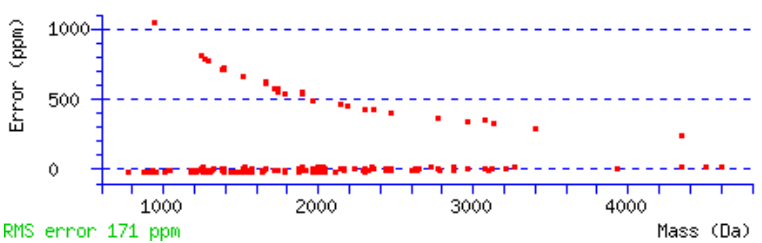


Table S3. Theoretical fragment ions obtained for the tryptic peptide QNPDIVICQYMDDLYVGSDLEIGQHRW. Identified ions found in the spectrum shown in Fig. 5 are indicated in red.

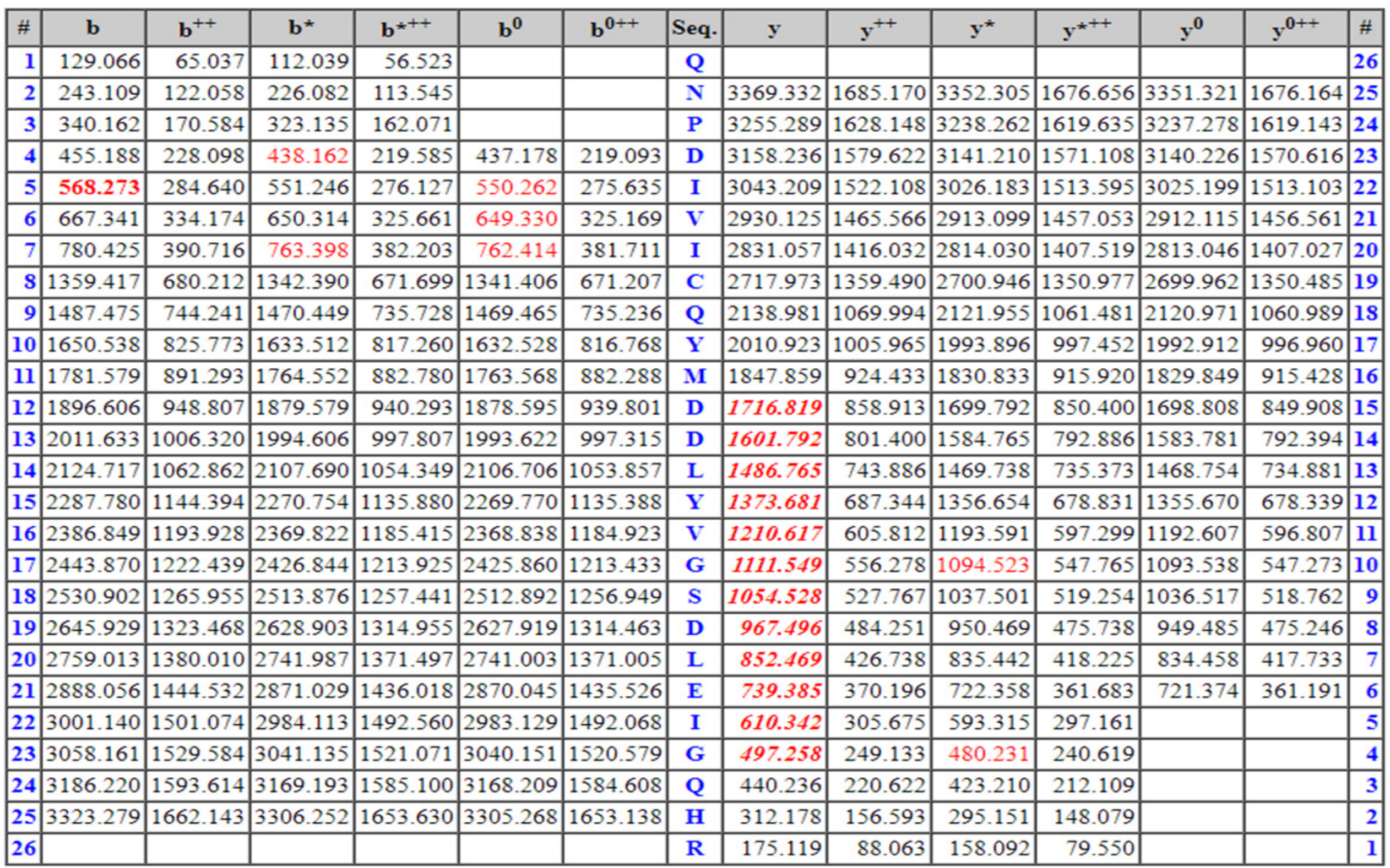

